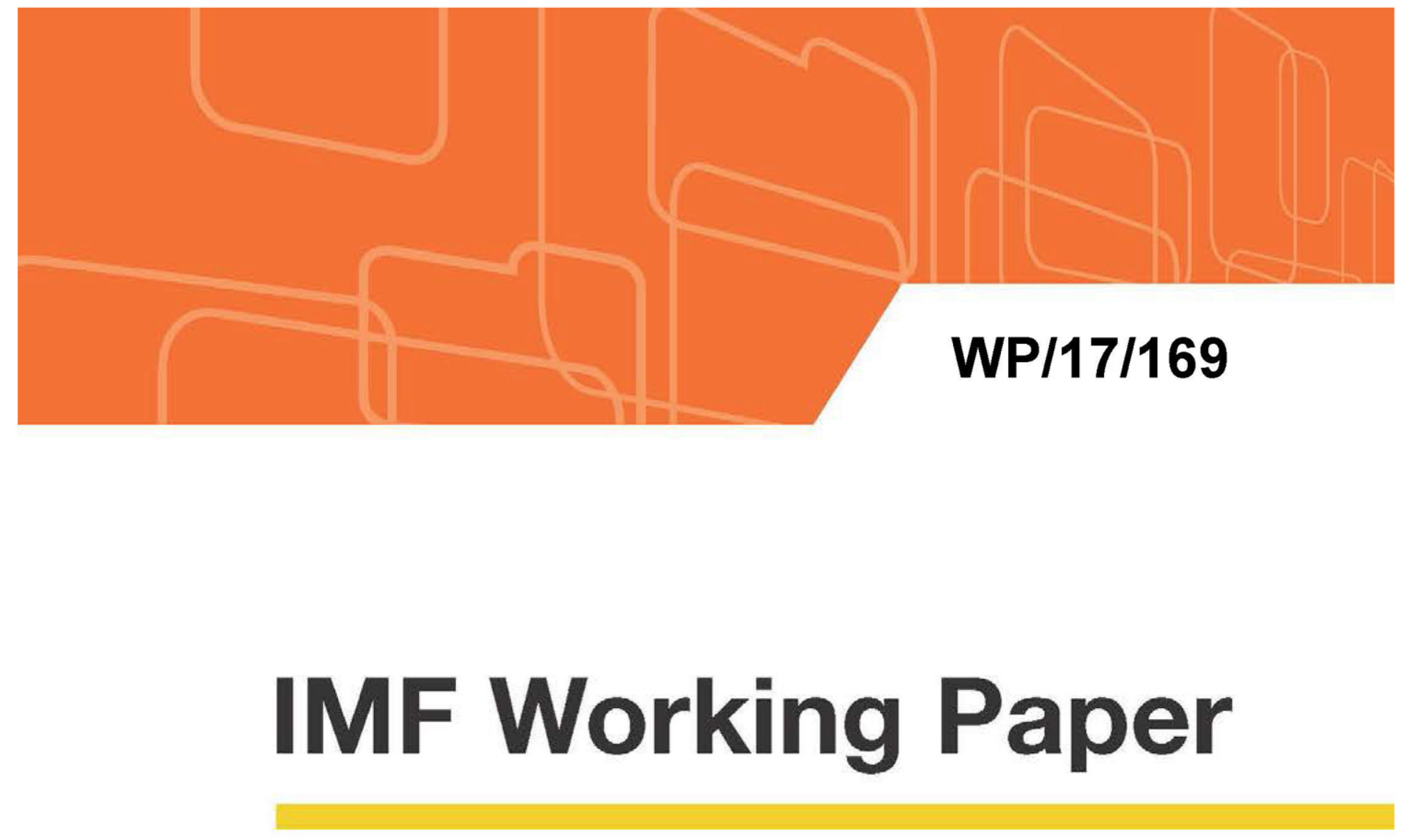

\title{
Why Is Labor Receiving a Smaller Share of Global Income? Theory and Empirical Evidence
}

by Mai Chi Dao, Mitali Das, Zsoka Koczan, Weicheng Lian

IMF Working Papers describe research in progress by the author(s) and are published to elicit comments and to encourage debate. The views expressed in IMF Working Papers are those of the author(s) and do not necessarily represent the views of the IMF, its Executive Board, or IMF management. 


\title{
WP/17/169
}

\section{IMF Working Paper}

\begin{abstract}
Why Is Labor Receiving a Smaller Share of Global Income? Theory and Empirical Evidence
\end{abstract}

by Mai Chi Dao, Mitali Das, Zsoka Koczan, Weicheng Lian

IMF Working Papers describe research in progress by the author(s) and are published to elicit comments and to encourage debate. The views expressed in IMF Working Papers are those of the author(s) and do not necessarily represent the views of the IMF, its Executive Board, or IMF management. 


\title{
IMF Working Paper
}

Research Department

\section{Why is Labor Receiving a Smaller Share of Global Income? Theory and Empirical Evidence.}

\author{
Prepared by Mai Chi Dao, Mitali Das, Zsoka Koczan, Weicheng Lian ${ }^{1}$
}

Authorized for distribution by Oya Celasun

July 2017

\begin{abstract}
IMF Working Papers describe research in progress by the author(s) and are published to elicit comments and to encourage debate. The views expressed in IMF Working Papers are those of the author(s) and do not necessarily represent the views of the IMF, its Executive Board, or IMF management.
\end{abstract}

\begin{abstract}
This paper documents the downward trend in the labor share of global income since the early 1990s, as well as its heterogeneous evolution across countries, industries and worker skill groups, using a newly assembled dataset, and analyzes the drivers behind it. Technological progress, along with varying exposure to routine occupations, explains about half the overall decline in advanced economies, with a larger negative impact on middle-skilled workers. In emerging markets, the labor share evolution is explained predominantly by global integration, particularly the expansion of global value chains that contributed to raising the overall capital intensity in production.
\end{abstract}

JEL Classification Numbers: E25, F66, O33

Keywords: labor share, routinization, automation, global value chains Author's E-Mail Address: MDao@imf.org; MDas@imf.org; ZKoczan@imf.org; WLian@imf.org

\footnotetext{
${ }^{1}$ The authors would like to thank Rob Feenstra, Brent Neiman and Maury Obstfeld for detailed discussions and guidance. We also thank Oya Celasun, Romain Duval, Gian Maria Milesi-Ferretti, Paolo Mauro, Petia Topalova and seminar participants at the IMF, the Free University Berlin, the NIESR London, the Joint Vienna Institute, the International Labor Organization, the World Trade Organization, the European Central Bank, EBRD, the Bank of England, the Bank of Spain, the German Ministry of Finance, the German Ministry of Labor, the Central Bank of Russia, the Reserve Bank of India and the Monetary Authority of Singapore, the Central Bank of Malaysia, the Bank of Japan, the Ministry of Finance of Japan, NIPFP Delhi, IGIDR Mumbai, the Asian Development Bank, and the Central Bank of the Philippines for very helpful comments on earlier drafts of the paper. Benjamin Hilgenstock and Hao Jiang provided outstanding research assistance. We also thank Alimata Kini Kabore, Meron Haile and Joe Procopio for excellent editorial assistance.
} 
Abstract $\underline{2}$

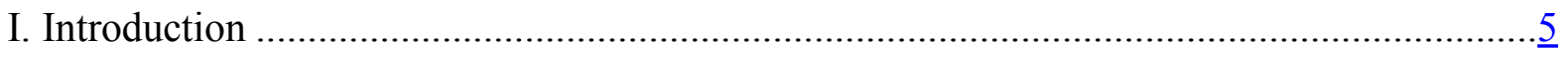

II. Trends in the Labor Share of Income: Key Facts...........................................................

III. Drivers of the Labor Share of Income: Key Concepts and Mechanisms............................15

IV. Analyzing Trends in the Labor Share of Income: Empirical Analysis...............................23

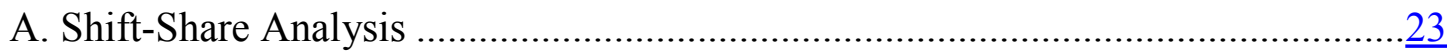

B. Analysis of Long-Term Changes in the Aggregate Labor Share of Income............24

C. Robustness of Aggregate-Level Regression Results..................................................29

D. Analysis of Long-Term Changes in Sectoral Labor Shares......................................

E. Analysis of Long-Term Changes in Labor Shares by Skill.......................................34

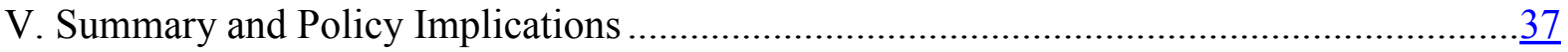

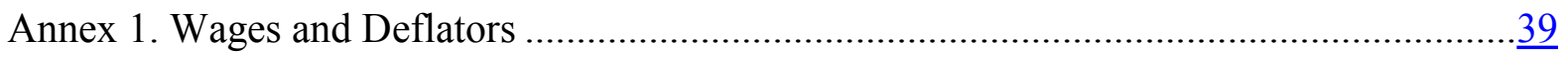

Annex 2. A Theoretical Model of Relative Cost of Capital, Offshoring, and Labor Shares of Income in Advanced Economies and Emerging Market and Developing Economies.....................................................................................

Annex 3. Country Coverage and Data .................................................................................. 46

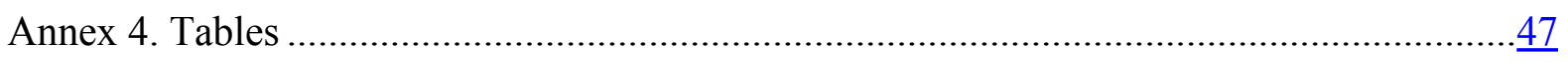

Annex 5. Appendix figures ...........................................................................................

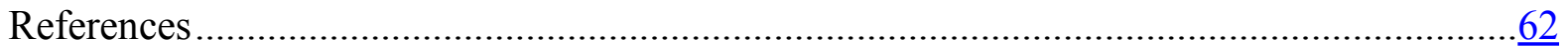

Figures

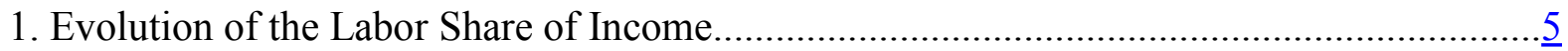

2. Labor Shares and Income Inequality ………………..................................................

3. Distribution of Estimated Trends in Labor Shares, 1991-2014 ………………................

4. Estimated Trends in Labor Shares by Country and Sector .................................................13

5. Labor Share Evolutions and Labor Force Composition by Skill Level ...............................14

6. Trends in Potential Drivers of Labor Shares....................................................................

7. Change in the Relative Price of Investment and Capital Intensity ....................................17

8. Changes in Global Value Chain Participation and Capital Intensity....................................20

9. Evolution of the Adjusted Labor Share of Income ............................................................. 


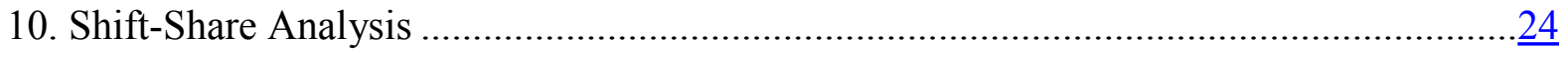

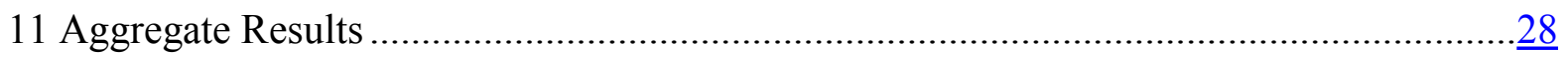

12. Heterogeneity across Sectors and Countries............................................................

13. Sectoral Results, Advanced Economies.........................................................................

14. Contributions to Aggregate Labor Share Change by Skill, 1995-2009 …………..............

15. Decomposition of the Labor Share of Income, 1991-2014 ..............................................

16. Product Wages, Consumption Wages, and Productivity in Manufacturing ....................... 40

17. Impact of the Costs of Capital and Offshoring on the Set of Tasks Offshored from a High-Wage County to a Low-Wage County ......................................................... 45

Appendices

1. Estimated Trends in Labor Shares across the World ........................................................... 60

2. Heterogeneity in the Evolution of Key Drivers of the

Labor Share

Tables

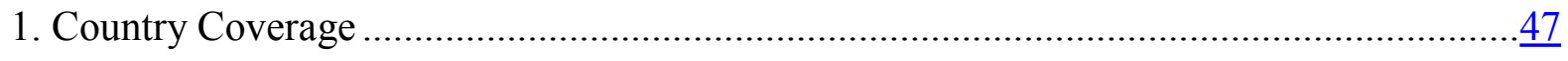

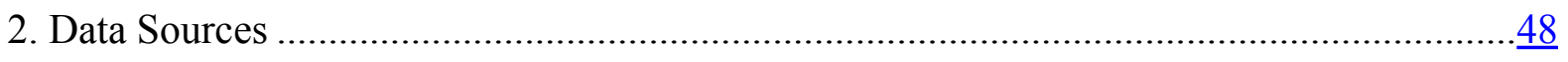

3. Baseline Aggregate Results ............................................................................................

4. Stacked Aggregate Results ……………………………......................................

5. Aggregate Results, Robustness (User Cost) .............................................................

6. Aggregate Results, Robustness (Alternative Measure of Offshoring)..................................

7. Aggregate Results, Robustness (Other Robustness Checks) ………………………...........

8. Aggregate Results, Robustness (Measurement Issues)........................................................54

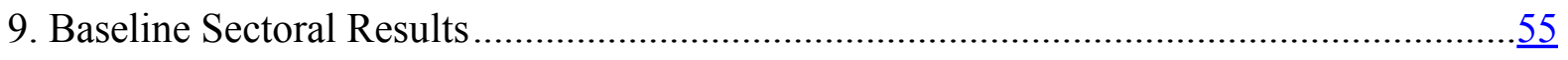

10. Aggregate Results by Skill Level .............................................................................

11. Sectoral Results by Skill Level ...............................................................................

12. Sectoral Results by Skill Level, Controlling for Skill Compensation ..............................

13. Sectoral Results by Skill Level, Controlling for Policy Institution Variables .....................59 


\section{INTRODUCTION}

The labor share of income - the share of national income paid in wages, including benefits, to workers - has been on a downward trend in many countries (Figure 1). In advanced economies, labor income shares began trending down in the 1980s, reaching their lowest level of the past half century just prior to the global financial crisis of 2008-09, and have not recovered materially since. Data are more limited for emerging market and developing economies, but in more than half of them - and especially the larger economies in this group-labor shares have also declined since the early 1990s. At the same time, the extent of the declines has been diverse across countries, both within the advanced economy and emerging market economy groups.

A falling labor share implies that product wages grow more slowly than average labor productivity. ${ }^{2}$ If labor productivity increases at a rapid pace due to technological progress, and this is accompanied by steadily rising labor incomes, a declining labor share may be viewed as a byproduct of a favorable development. However, in a number of economies, declining labor shares result from the failure of product wage growth to keep up with weak productivity growth. ${ }^{3}$ Furthermore, the decline in the labor share has been concomitant with increases in income inequality

\section{Figure 1. Evolution of the Labor Share of Income (Percent)}

The labor share of income has been on a downward trend in both advanced economies and emerging market and developing economies.

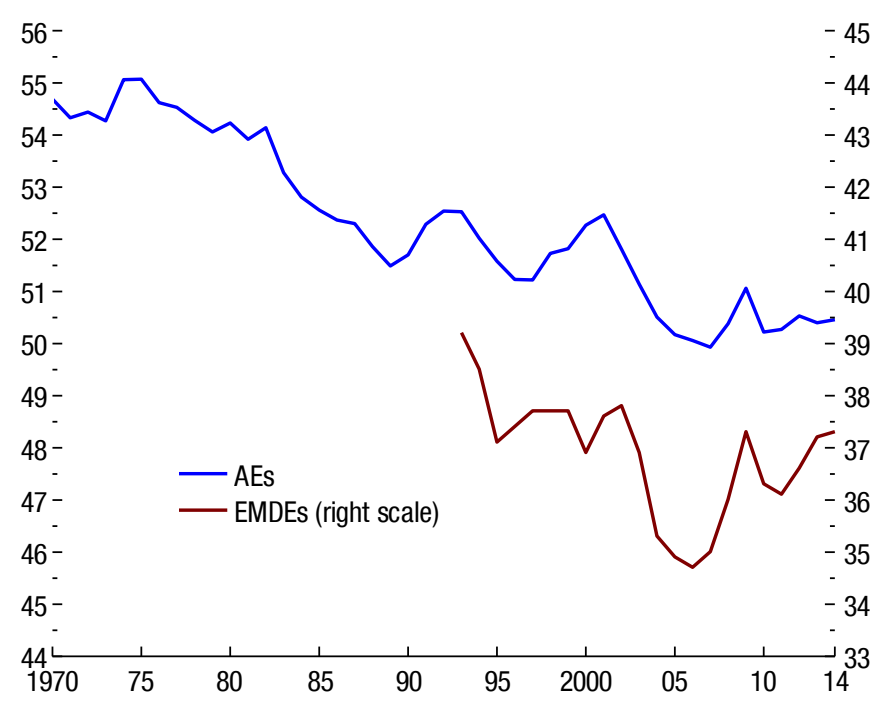

Sources: CEIC database; Karabarbournis and Neiman (2014); national authorities; Organisation for Economic Co-operation and Development; and IMF staff calculations.

Note: For AEs the figure shows averages weighted by nominal GDP in current U.S. dollars. For EMDEs the figure shows year fixed effects weighted least squares regressions (using nominal GDP weights) that also include country fixed effects. Year fixed effects are normalized to reflect the level of the labor share in 2000. AEs = advanced economies; EMDEs = emerging market and developing economies.

(Figure 2), for two reasons. The first is

\footnotetext{
${ }^{2}$ The labor share of income can be written as: $(w L) /(P Y)=(w / P) /(Y / L)$, in which $w$ is the money wage (including benefits) per worker, $L$ is employment (hours worked), $Y$ is real output, $Y / L$ is therefore labor productivity, and $P$ is the GDP deflator. Because $w / P$ is the wage expressed in units of domestic output, it is also called the (real) product wage. The product wage may differ from the consumption wage (that is, wages measured in terms of consumption), as the latter takes into account the terms of trade (the price of imports in terms of exports) and is a preferred measure of the purchasing power of workers' wage income (Annex 1).

${ }^{3}$ On the link between wages and productivity, see ILO 2015c. On the productivity slowdown, see Ollivaud, Guillemette, and Turner 2016 and IMF, 2017a.
} 
that within the workforce, lowerskilled workers have borne the brunt of the fall in labor share amid evidence of persistent declines in middle-skilled occupations and income losses for middle-skilled workers in advanced economies (Autor and Dorn 2013; Goos, Manning, and Salomons 2014). The second is that capital ownership is typically concentrated among the top of the income distribution (Wolff 2010) and hence an increase in the share of returns accruing to capital tends to raise income inequality.

Inequality can fuel social tension, and recent research suggests that it can also harm economic growth (Berg and Ostry 2011). Low productivity growth, if persistent, leaves little room for expectations of future wage growth short of a reversal in favor of higher labor shares. As the global economy continues to struggle with subpar growth, a growing recognition that the gains from growth often have not been broadly shared has strengthened a backlash against economic integration and bolstered support in favor of inward-looking policies.

The forces behind the apparently widespread decline in labor income shares and the diversity of country experiences are not yet well understood. The fact that many advanced and emerging market and developing economies have experienced declines through somewhat synchronized evolutions - through domestic business cycles and over a period of profound structural transformation in advanced and emerging market economies alikesuggests key driving forces that are likely global. At the same time, varying exposures to
Figure 2. Labor Shares and Income Inequality

Lower labor shares are strongly associated with higher income inequality (measured by Gini coefficients) both across countries and over time within countries.
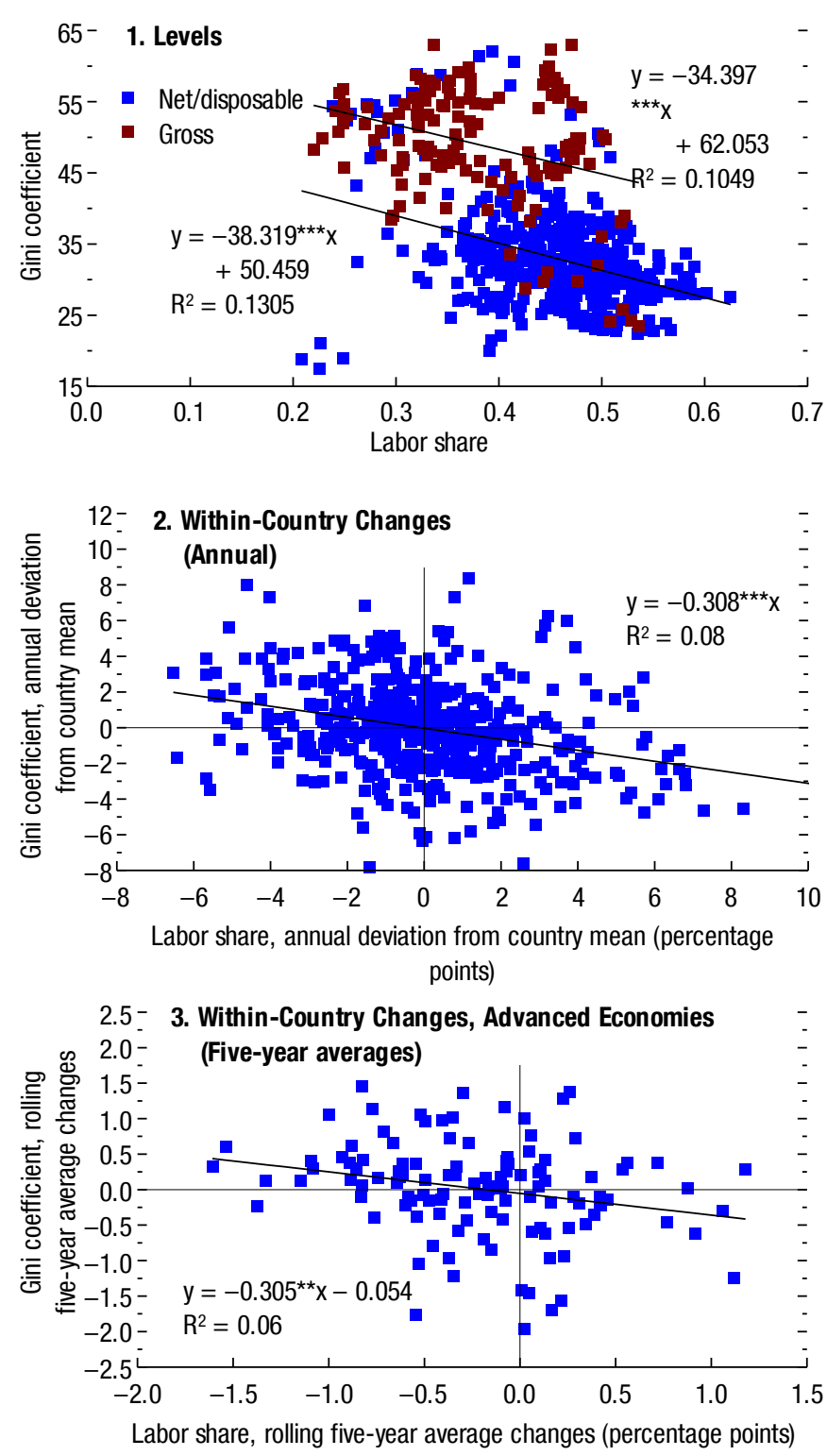

Sources: CEIC database; Karabarbounis and Neiman (2014); national authorities; Organisation for Economic Co-operation and Development; World Bank, All the Ginis database; and IMF staff calculations. Note: ${ }^{\star \star \star}$ indicates 1 percent statistical significance; ${ }^{* \star}$ indicates 5 percent statistical significance. 
common global trends may help explain the diversity in labor share trends across countries (Figure 3 ).

Analysts focusing predominantly on the United States and advanced economies have concentrated on two leading explanations for the downward trends in labor shares: the rapid advance of technology and the globalization of trade and capital. ${ }^{4}$ There is broad consensus that, notwithstanding the considerable adjustment costs these forces have imposed on some groups of workers, both trends have contributed strongly to overall growth and prosperity worldwide as well as to income convergence in emerging market and developing economies. In particular, the benefits of trade and financial integration to emerging market and developing economies - where they have fostered convergence, raised incomes, expanded access to goods
Figure 3. Distribution of Estimated Trends in Labor Shares, 19912014

(Percentage points per 10 years)

The evolution of the labor share of income has been heterogeneous noticeably more in emerging market and developing economies than in advanced economies.

$$
5-
$$
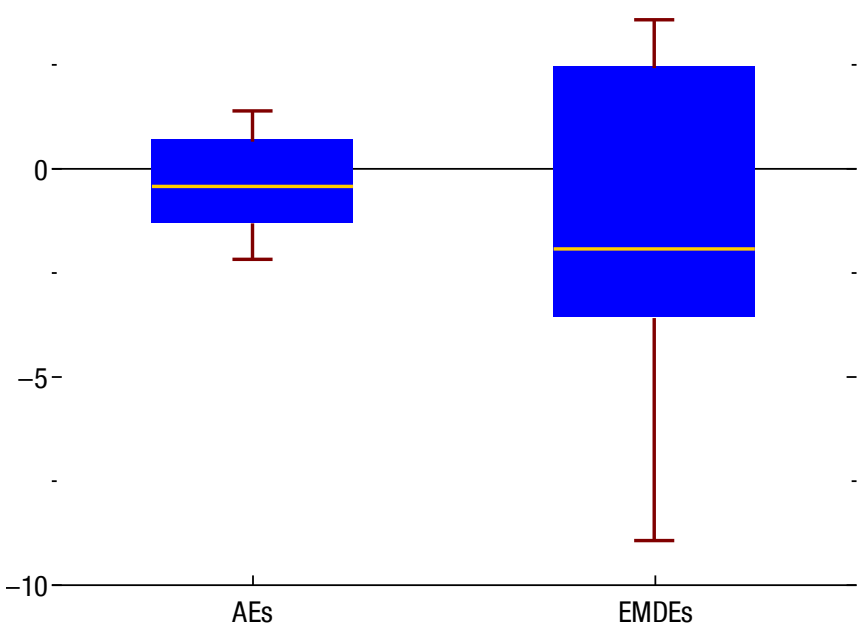

Sources: CEIC database; Karabarbounis and Neiman (2014); national authorities; Organisation for Economic Co-operation and Development; and IMF staff calculations.

Note: The horizontal line inside each box represents the median; the upper and lower edges of each box show the top and bottom quartiles; and the red markers denote the top and bottom deciles. AEs = advanced economies; EMDEs $=$ emerging market and developing economies.

and services, and lifted millions from poverty - are well documented. ${ }^{5}$ Even though product wages have grown more slowly than average productivity in some emerging market and developing economies, the rise in product wages has, to some extent, been driven by the integration of these countries into the global economy. Indeed, the rise in inequality in some emerging market economies must also be viewed in the context of rising income levels for

${ }^{4}$ See, for example, Blanchard 1997; Elsby, Hobijn, and Şahin 2013; Rognlie 2015; Autor and others 2017; and Acemoglu and Restrepo 2016 for analyses of the United States and other advanced economies. Chapter 5 of the April 2007 WEO documents shifts in employment across sectors and technological advancement as the key contributors to the evolution of labor shares in advanced economies during 1980-2002. See Harrison 2002; Rodrigues and Jayadev 2010; and Karabarbounis and Neiman 2014 for analyses that include emerging market economies.

${ }^{5}$ The benefits of global economic integration are widely documented. A recent summary is in Baldwin (2016). See also, Fajgelbaum and Khandelwal (2016), Costinot and Rodriguez-Clare (2014), Wacziarg and Welch (2008), Section 2 in Chapter 2 of the October 2016 World Economic Outlook, and IMF/WB/WTO (2017). Chapter 2 of the April 2017 WEO documents that stronger capital inflows have tended to come with higher per capita growth in emerging market and developing economies. 
those at the bottom of the income distribution (OECD 2011 and World Bank 2016). At the same time, empirical analysis has shown that, in some advanced economies, the automation of jobs, along with offshoring and import competition, have led to persistent losses of jobs in middle-skilled occupations. ${ }^{6}$

One way in which technological advancement has affected factor shares is through a steep decline in the relative price of investment goods, which has lowered firms' cost of capital and therefore has given them strong incentives to replace labor with capital (Karabarbounis and Neiman 2014). ${ }^{7}$ The paper makes two key contributions on this front. First, it explores whether the rapid advance in information and communications technology, which underpins much of the decline in the price of investment goods, has lowered labor shares by encouraging the automation of routine tasks. ${ }^{8}$ To this end, the paper introduces measures of exposure to routinization to assess whether the declining price of investment has led to a greater decline in labor shares in more exposed countries and industries. ${ }^{9}$ Second, the paper highlights that, while the relative price of investment has declined steeply in advanced economies, it has experienced a milder decline in emerging market economies, where it has even risen in some (Appendix Figure 2).

Trade and financial integration have increased dramatically over the past 25 years. This process has been driven by the removal of restrictions on international trade and capital mobility, as well as by declining transportation and communication costs, which have themselves been facilitated by technological progress. Economic integration has brought about domestic factor reallocation in response to import competition; promoted the relocation of lower-skill, labor-intensive stages of production to cheaper locations in emerging and developing economies; and may have lowered the relative cost of capital. By increasing

\footnotetext{
${ }^{6}$ Autor and Dorn 2013 provide evidence of a link between the adoption of information technology and the polarization of employment and wages in the United States, whereas Autor, Dorn, and Hanson 2016 and Pierce and Schott 2016 document employment losses in U.S. industries more exposed to import competition from China. Goos, Manning, and Salomons 2014 provide evidence that routine-biased technological change, and to a much lesser extent, offshoring of tasks, can explain job polarization in European advanced economies.

${ }^{7}$ The channel by which technological progress affects the labor share is by lowering the user cost of capital, inducing firms to substitute capital for labor. The impact on the labor share depends on the elasticity of substitution between labor and capital. The user cost of capital is the annual opportunity cost of using rather than selling existing capital, and increases with the price of capital, the interest rate, the depreciation rate, and the expected decline in the price of capital. Technology that produces investment goods more efficiently lowers the price of capital and thus the user cost. A decline in interest rates or capital depreciation rates could play a role similar to that of technological progress in lowering the user cost of capital.

${ }^{8}$ The role of information and communications technology in the price of investment is discussed in Krusell 1998; its role in the displacement of labor through the automation of routine tasks is discussed in Autor and Dorn 2013, and Goos, Manning, and Salomon 2014.

${ }^{9}$ Eden and Gaggl (2015) illustrate the impact of routine and nonroutine tasks on U.S. labor shares in a calibration exercise.
} 
competitive pressure on domestic firms and credibly raising their ability to relocate abroad, trade and financial integration may have also lowered labor's bargaining power.

Traditional theories of trade based on international differences in given factor endowments predict that trade integration will reduce labor shares in capital-abundant advanced economies but raise them in labor-abundant emerging market economies. The actual evolution of labor shares in the latter group of countries is, however, at odds with this prediction. As alluded to above, the process of integration is more complex than captured by classical trade models, as it involves movement of factors across borders, technology transfers, and shifts in relative bargaining power between capital and labor. This paper highlights a mechanism by which participation in global value chains can simultaneously lead to lower labor shares in advanced and emerging market economies, and explores empirically whether trade and financial integration in general — and participation in global value chains in particular-is correlated with the evolution of labor shares.

Other explanations for the downward trends in labor shares are also possible. The regulation of labor and product markets is an important determinant of both the size of profits and their distribution between capital and labor (Blanchard and Giavazzi 2003). Changes in product market structure that favor agglomeration, for example, may have increased concentration across a number of industries, raising profit shares and lowering the labor share of income (Council of Economic Advisers 2016; Autor and others 2017). Changes in policies (such as declining corporate income tax rates) may have strengthened incentives to substitute capital for labor, while changes in institutional arrangements - such as unionization ratesmay have contributed to the decline in labor's share of income by lowering labor's bargaining power. ${ }^{10}$

Finally, as noted in Gollin (2002) and Bridgman (2014), there are two measurement problems that present well-known challenges to the analysis of labor shares: self-employed individuals, whose labor compensation is not recorded separately in national income accounts; and the depreciation of capital, which should arguably be removed from the calculation of factor shares as it does not reflect net capital income. Though data limitations constrain the use of adjusted measures of labor shares for all of the analysis, the paper considers robustness of the results to allow for both of these considerations. The paper focuses in particular on the following questions:

- How widespread has the decline in the labor share of income been since the early 1990s? To what extent have trends in labor income shares differed across countries, industries and skill groups?

\footnotetext{
${ }^{10}$ Some evidence for the impact of declining bargaining power on lowering labor shares is in Kramarz 2016 and OECD 2012.
} 
- What are the key drivers of the labor share of income and through which mechanisms do they operate? Do the drivers vary between advanced economies and emerging market and developing economies, industries, and skill groups?

- How have exposures to routinization and participation in global value chains affected labor shares? What roles have regulations of labor and product markets played?

The paper begins by documenting stylized facts about recent trends in labor shares of income. It then presents the mechanisms by which key drivers can influence labor share dynamics. The paper then employs two complementary approaches to analyze long-term changes in labor shares. The first approach is a shift-share analysis that determines whether the downward trend in the global labor share is driven by within-industry declines (declines within individual industries, such as manufacturing or transportation) or by changes in industrial composition (shifts from high-labor-share sectors to low-labor-share sectors). The second approach, which constitutes the core of the empirical analysis, quantifies the extent to which drivers can track long-term changes in labor income shares. This analysis is conducted using a newly assembled data set on aggregate and sectoral labor shares for both advanced economies and emerging market and developing economies, in addition to data on labor shares of different skill groups. ${ }^{11}$

In this paper, global integration is measured by three variables: trade in final goods and services (proxied by value-added exports and imports relative to GDP); participation in global value chains (proxied by the sum of forward and backward linkages [see Annex 3.4 for details]); and financial integration (proxied by the sum of external assets and liabilities excluding reserves, in percent of GDP). Although the paper treats global integration and technology as distinct drivers of labor shares, they are both conceptually and empirically difficult to disentangle. For instance, technological advances have likely facilitated economic integration by lowering communication and logistic costs, but economic integration has plausibly eased the diffusion of technology across borders. It should therefore be kept in mind that their effects cannot be fully separated out and results should be interpreted in light of these empirical challenges. The paper's main findings are as follows:

- $\quad$ Between 1991 and 2014, the labor share declined in 29 of the largest 50 economies; those 29 economies accounted for about two-thirds of world GDP in 2014. Across industries, labor income shares have declined in 7 of the 10 major industries, with the sharpest declines occurring in the more tradable sectors, such as manufacturing, and transportation and communication.

\footnotetext{
${ }^{11}$ The sectoral labor share data on emerging market and developing economies is new to this paper. It is compiled using official sources and is described in detail in Annex 3.3 and Dao and others (forthcoming).
} 
- $\quad$ The decline in the labor share of income between 1993 and 2014 appears to result from within-industry declines, rather than a shift from high-labor-share sectors to sectors with relatively lower labor shares. A shift-share decomposition, which separates such within-industry changes and between-industry changes, reveals that more than 90 percent of changes in labor income shares reflect within-industry changes rather than sectoral reallocation. An important exception is China, where reallocation from agriculture to other industries accounts for the majority of the decline in the labor share of income.

- Technological advancement, measured by the long-term change in the relative price of investment goods, together with the initial exposure to routinization, have been the largest contributors to the decline in labor income shares in advanced economies. The empirical analysis suggests that about half of the total decline in labor shares can be traced to the impact of technology. Importantly, for a given change in the relative price of investment, economies with high exposure to routinization experienced about four times the decline in labor income shares than those with low exposure. Global integration has also played a role, largely by lowering labor shares in tradables sectors. The quantitative impact of changes in policies and institutions, and reforms in product and labor markets, appears to be limited but may reflect in part the difficulty of empirically separating trends in global integration and de-unionization. The results for the advanced economy composite mirrors the results for individual economies, where technology is the largest contributor to the change in labor shares in the large majority of countries.

- In emerging market economies as a whole, global integration, and more specifically, participation in global value chains, appears to be an important factor behind the decline in the labor share of income. Its impact has been partly offset by financial integration, which has raised labor shares, conceivably by lowering the cost of capital, as well as by the limited substitutability between labor and capital in these economies. For emerging market economies in the aggregate, there is no discernible role of technology in the evolution of labor shares. This reflects both a relatively mild decline in the relative price of investment goods and, importantly, a much lower exposure to routinization, which has limited labor displacement arising from routinebiased technology. However, the results for the emerging market composite mask significant differences across individual economies, resulting from substantial 
diversity in the evolution of the relative prices of investment goods as well as the initial exposures to routinization in these economies. ${ }^{12}$

- The decline in labor shares driven by technology and global integration has been particularly sharp for middle-skilled labor. This finding is consistent with the hypothesis that routine-biased technology has taken over many of the tasks performed by middle-skilled labor, contributing to job polarization toward high-skill and lowskill occupations.

- $\quad$ Adjustments to the labor share of income for self-employment and capital depreciation rates, which present the two measurement challenges confronting labor share data, can have important effects on both the level and evolution of labor shares. However, for both advanced and emerging market economies, findings about the key drivers of the unadjusted labor shares are robust to adjustments for both selfemployment and depreciation rates.

\section{TrendS In THE LABOR SHARE OF InCOME: Key FaCtS}

The global labor share of income began a downward trend in the 1980s, declining 5 percentage points to its trough in 2006. It has since then trended up by about 1.3 percentage points, which may reflect either cyclical or structural factors associated with the global financial crisis. This downward trend has overturned one of the enduring stylized facts in Kaldor (1957), which supported a long tradition of assuming a constant labor share of income in growth and other macroeconomic models, and thus raised complex questions about the rising role of capital in production and its implications for the future of employment and labor income.

This paper focuses on the past two decades — 1991 through 2014 — during which the global labor share of income declined by some 2 percentage points, because this is a period of significant flux in the global economy through trade, technology, and political changes, including the transformation of global labor markets following the entry of China, India, and former Eastern bloc countries into the world economy in the early 1990s. ${ }^{13}$ In particular, the period since 2000 saw an acceleration of global integration following China's accession to the World Trade Organization, along with rapid increases in emerging market investment in infrastructure and education that led to a surge in offshoring to these economies (Obstfeld, 2016). As a result of both offshoring and technological advances, routine occupations in advanced economies became increasingly automated in this period,

\footnotetext{
${ }^{12}$ By contrast, the trend change in participation in global value chains is much more homogeneous across the emerging market economies in the sample, implying a more homogeneous impact on the change in their labor shares.

${ }^{13}$ The chosen period also serves to maximize data coverage of emerging market and developing economies.
} 
contributing to a deep decline in middle-skilled employment (Autor and Dorn 2013 and Goos, Manning and Salomons 2014). In recent years, the global economy has undergone further structural changes - a protracted period of weak growth, a trade slowdown, and a deceleration of total factor productivity growth - which, coupled with demographic shifts, have all likely affected labor income shares.

\section{Figure 4. Estimated Trends in Labor Shares by Country and Sector}

While the downward trend in the labor share of income is fairly broad-based across countries and industries, there is tremendous diversity in their evolution.
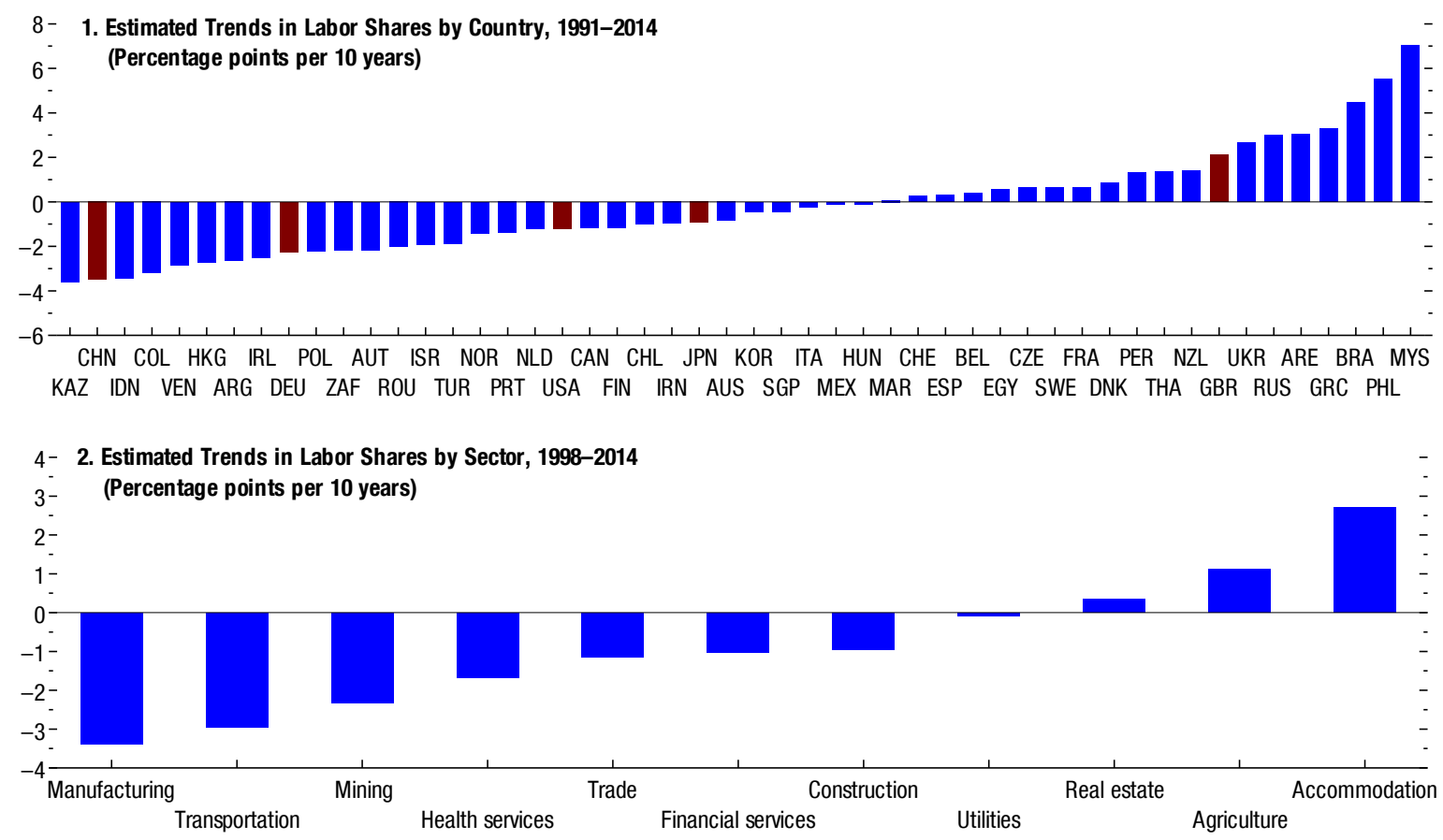

Sources: CEIC database; Karabarbounis and Neiman (2014); national authorities; Organisation for Economic Co-operation and Development; and IMF staff calculations.

Note: The figure shows estimated trends in labor shares. In the first panel, the largest five economies are highlighted in red. Data labels in the figure use International Organization for Standardization (ISO) country codes.

A less well-known fact about the fall in labor shares at the global level is that it reflects declining shares in both advanced and, to a lesser extent, emerging market and developing economies. ${ }^{14}$ Indeed, the labor share of income has declined in four of the world's five largest economies, led by the steepest decline in China, while the labor share of income in the United Kingdom has trended up (Figure 4, panel 1 and Appendix Figure 1). At the same time, the evolution of the labor share within each of these country groups has been heterogeneous (Figure 3). In a sample of 35 advanced economies between 1991 and 2014, the

\footnotetext{
${ }^{14}$ This finding corroborates that of Karabarbounis and Neiman (2014). Relative to that paper, our paper's data cover a larger number of countries and extend their time period by up to four years. Importantly, the data used in this paper includes significant revisions to the official labor share data for systemically large countries such as Germany, the United Kingdom, China, and Brazil.
} 
labor share declined in 19, which accounted for 78 percent of 2014 GDP, and rose or remained relatively stable in the remainder. The overall cross-country dispersion of labor shares is considerably larger in emerging market and developing economies than in advanced economies. ${ }^{15}$ In a sample of 54 emerging market and developing economies (for which, on average, the decline in the labor share over the sample period is concentrated in the early 1990s), the labor share declined in 32 economies, which accounted for about 70 percent of 2014 emerging market GDP, while rising or remaining roughly constant in the rest.

The broad contours of the decline in the global labor share of income also conceal a heterogeneous evolution across industries (Figure 4, panel 2). ${ }^{16}$ At the global level, the sharpest decline in the labor share was in manufacturing, followed by transportation and communication, while some sectors (food and accommodation, agriculture) witnessed an increase. This global picture reflects largely developments in advanced economies; in emerging market and developing economies, the sharpest decline was observed in agriculture, and labor shares rose in manufacturing and, particularly, in health services and construction. This partly reflects the industrial labor share evolution in China, given its increasing GDP weight in this country group since 1993.

The decline in the global labor share has been borne by low- and middle-skilled labor. During 19952009 their combined labor income share was reduced by more than 7 percentage points, while the global

\section{Figure 5. Labor Share Evolutions and Labor Force Composition by Skill Level (Percent)}

The decline in the labor share of income for low- and middle-skill workers has been especially pronounced, with the decline for middle-skill labor driven primarily by a decline in their relative wage rate.
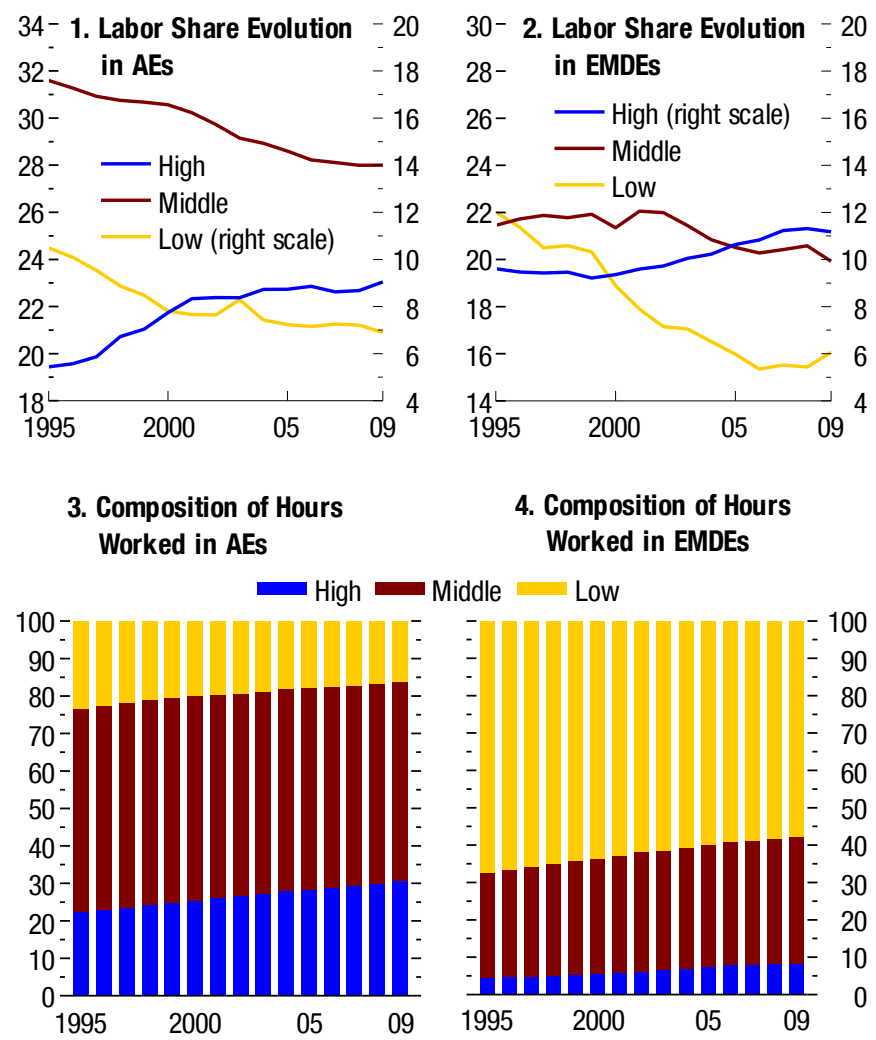

Sources: World Input-Output Database; and IMF staff calculations. Note: $\mathrm{AEs}=$ advanced economies; EMDEs = emerging market and developing economies.

\footnotetext{
15 The standard deviation of long-term changes in labor shares was 4.8 across emerging market and developing economies and 1.5 across advanced economies.

${ }^{16}$ Sector-level data country coverage is smaller than aggregate labor share data coverage for emerging market and developing economies and spans a slightly shorter period.
} 
high-skilled labor share increased by more than 5 percentage points (Figure 5, panels 1-2). The decline in middle-skilled labor's income share was driven primarily by a drop in their relative wage rate. The share of middle-skill employment in the total workforce remained stable or even rose (Figure 5, panels 3-4), while the labor share decline for low-skilled labor and the increase for high-skilled labor were also driven, to a large extent, by the diverging trend in employment composition, reflecting rising levels of education. This pattern is consistent with the notion that technological progress has been biased in favor of high-skilled labor. ${ }^{17}$ Furthermore, while the broad patterns hold for both advanced and emerging market and developing economies, they are more pronounced in advanced economies, consistent with evidence of wage and employment polarization in these economies. ${ }^{18}$

\section{DRIVERS OF THE LABOR SHARE OF INCOME: Key CONCEPTS AND MECHANISMS}

This section provides a brief description of the key concepts, as well as the mechanisms by which the main drivers can influence the labor share of income.

A key parameter that influences the factor shares of income is the elasticity of substitution between capital and labor, which measures how easily one is substituted with the other when their relative cost changes. The role of this elasticity in the distribution of income has a rich conceptual and empirical history that originates in Arrow and others (1961). ${ }^{19}$ When capital is highly substitutable for labor (the elasticity of substitution is larger than 1), a decline in the relative cost of capital drives firms to substitute capital for labor to such a high degree that, despite the lower cost of capital, the labor share of income declines. As revealed by the illustrative model built for this paper, this elasticity of substitution can also play a role in the impact of offshoring on labor income shares. In particular, if, for the tasks offshored from high-wage to low-wage countries, capital cannot easily be replaced by labor (the elasticity of substitution is lower than 1), the labor income share may decline in the receiving country. ${ }^{20}$

\footnotetext{
${ }^{17}$ See Berman, Bound, and Griliches 1994. Jones and Romer (2009) reexamine Kaldor's (1957) stylized facts and highlight the long-term stability of relative wages. In particular, they note that the rising quantity of human capital relative to unskilled labor has not been matched by a sustained decline in its relative price, which they propose is explained by the skill-bias of technological change.

${ }^{18}$ Evidence of job polarization in the United States is presented in Autor and Dorn 2013 and for European economies in Goos, Manning, and Salomons 2014.

${ }^{19}$ The constant elasticity of substitution production function, which is widely used to analyze the functional distribution of income, originates in Arrow and others 1961, where it was presented as an alternative to the Cobb-Douglas and Leontief production functions and used to estimate labor's share of income on disaggregated cross-country data. See also Robinson 1933 and, more recently, Karabarbounis and Neiman 2014.

${ }^{20}$ The theoretical model (Annex 2, Proposition 1) suggests that offshoring from advanced economies may indeed involve tasks with lower elasticity of substitution. The key insight is that the capital deepening induced by a decline in the relative price of investment goods renders tasks with a high elasticity of substitution less
} 
With this key concept in mind, this section describes the main drivers of labor shares, dividing them into four broad categories: technological advancement; global integration; policies, institutions, and regulation of labor and product markets; and measurement issues. Although the first three drivers are treated as distinct channels for exposition, this is an artificial separation, as they are all potentially intertwined. In addition to the mutually reinforcing forces of technology and global integration described earlier, the evolution of country-specific policies, regulations, and reforms may themselves reflect global factors. For example, the decline in corporate taxation rates may reflect intercountry competition to attract capital in a globalized world where capital is freely mobile (Rodrik 1998). Similarly, declining unionization rates may reflect the decline of labor's bargaining power, itself a result of trade integration (Elsby, Hobijn, and Şahin 2013). It is therefore extremely difficult to quantify the distinct effects of each of these drivers.

\section{Technological Advancement:}

Technological progress, embodied in faster productivity growth in the capital goods sector relative to the rest of the economy, lowers the price of investment goods and thus induces firms to substitute capital for labor (Chapter 5 of the April 2007 WEO; ILO 2012; OECD 2012; Karabarbounis and Neiman 2014). This paper puts particular emphasis on the rapid advance of information and communications

labor-intensive, which in turn implies that firms benefit less from offshoring these tasks to low-wage destinations.

\section{Figure 6. Trends in Potential Drivers of Labor Shares}

The relative price of investment has declined more in advanced economies than in emerging market and developing economies. Countries with higher initial routine exposure experienced larger subsequent declines in labor shares. Global value chain participation increased, while corporate income taxes and union density rates declined in both sets of countries.
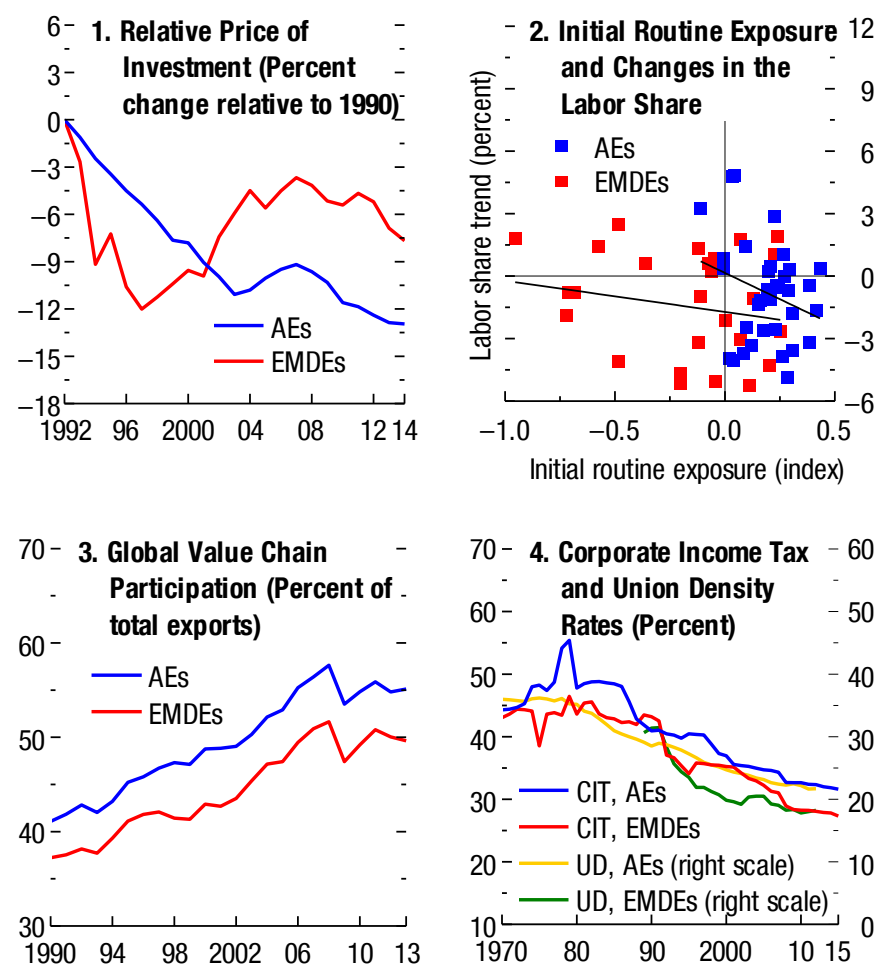

Sources: Autor and Dorn (2014); Eora Multi-Region Input-Output database; Integrated Public Use Microdata Series International; Integrated Public Use Microdata Series USA; International Labour Organization; Karabarbounis and Neiman (2014); national authorities; Organisation for Economic Co-operation and Development; United Nations database; World Input-Output Database; and IMF staff calculations.

Note: Panel 2 shows estimated trends in the labor share. Trend coefficients are reported on the $y$-axis in units per 10 years. Panels 1,3 and 4 show fixed effects from regressions that also include country fixed effects to account for entry and exit during the sample. The regressions are weighted by nominal GDP in current U.S. dollars. Fixed effects are normalized to reflect the respective variable's level in 1993. $\mathrm{AEs}=$ advanced economies; $\mathrm{CIT}=$ corporate income tax rate; EMDEs = emerging market and developing economies; UD = union density rate. 
technology, which accelerates the automation of routine tasks and thus induces firms to disproportionately substitute capital for labor where the exposure to such tasks is larger. The two mechanisms are likely to interact: a decline in the relative price of investment goods will trigger greater substitution away from labor, and this impact is likely more pronounced where labor performs more routine tasks.

The steep global decline in the price of investment is by and large an advanced economy phenomenon (Figure 6, panel 1). ${ }^{21}$ The milder overall decline experienced by emerging market and developing economies is explained, in large measure, by the smaller weight of information and communications technology capital and machinery and equipment (the group of capital goods that has led the decline in the relative price of investment) in their investment goods basket and the greater commodity intensity of their
Figure 7. Change in the Relative Price of Investment and Capital Intensity
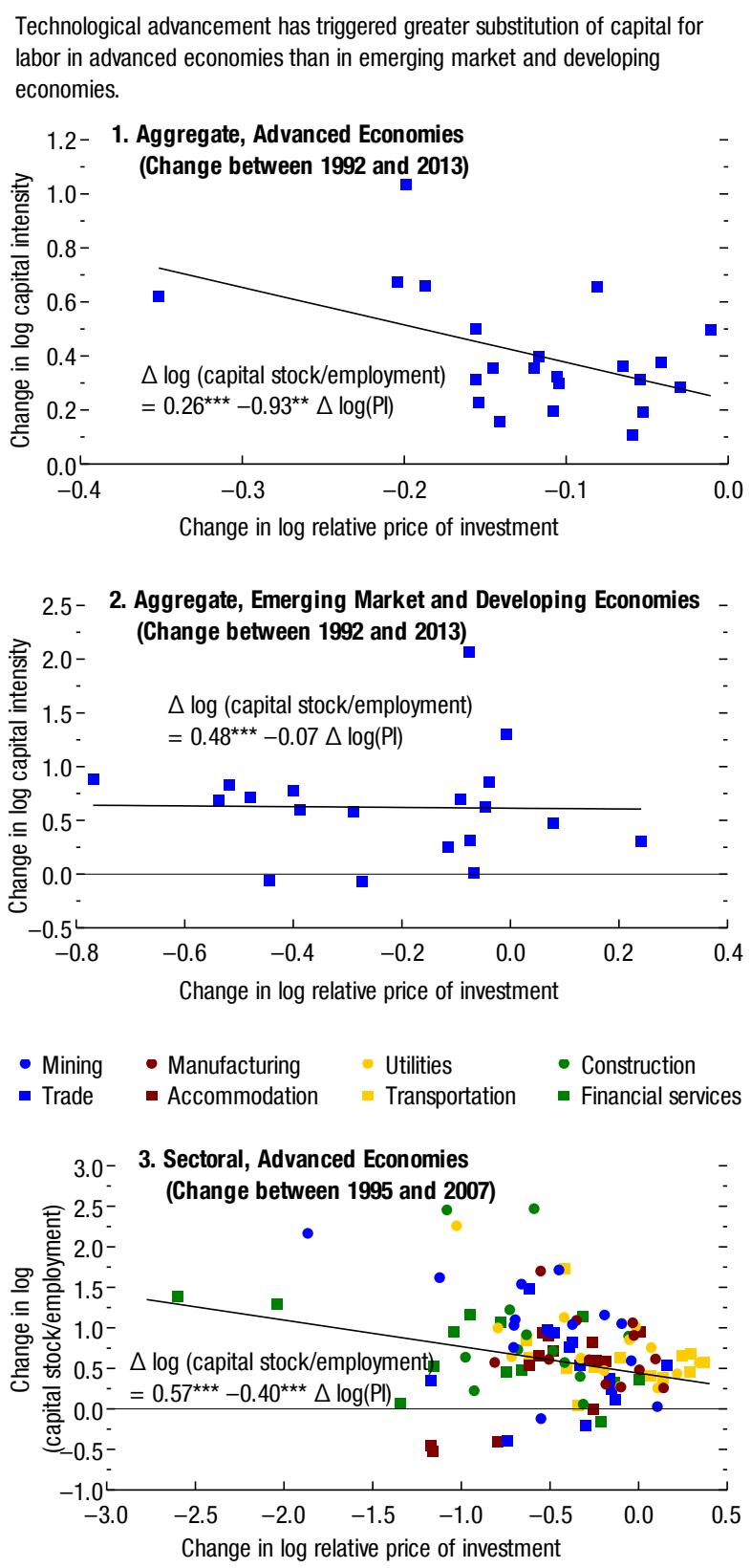

Sources: EU KLEMS database; Penn World Table 9.0 database; World InputOutput Database; and IMF staff calculations.

Note: Change in capital intensity refers to the change in log (capital stock/employment). $\mathrm{PI}=$ price of investment.

\footnotetext{
${ }^{21}$ Between 1993 and 2014 the relative price of investment declined by about 12 percent in advanced economies, reflecting declines in the clear majority of individual economies as well; and by about 7 percent in emerging market and developing economies as a whole, declining by less in several individual economies and even rising in some.
} 
investment. ${ }^{22}$ Countries also differ widely in their initial exposure to routinization, which exhibits a negative correlation with the subsequent change in labor shares of income (Figure 6, panel 2). ${ }^{23}$ On this aspect as well, emerging market and developing economies differ systematically from advanced economies, exhibiting substantially lower initial exposure to routinization.

Taken together, these two stylized facts suggest that advances in technology have triggered greater substitution of capital for labor in advanced economies than in emerging market and developing economies because the former were more exposed to automation of routine tasks and experienced a larger fall in investment good prices than the latter (Figure 7).

Global integration: Trade and financial integration are other factors widely viewed as a significant determinant of the evolution of labor shares (Harrison 2002; Rodrigues and Jayadev 2010; Chapter 5 of the April 2007 WEO; Elsby, Hobijn, and Şahin 2013). Several interrelated mechanisms — with potentially offsetting impacts — may be at play.

Trade integration: Traditional theory predicts that trade integration will lead capitalabundant advanced economies to specialize in the production of capital-intensive goods, triggering resource reallocation across sectors that lowers the labor share of income. The opposite is predicted to occur in labor-abundant emerging market and developing economies. Although this model is at odds with the decline in labor shares of emerging market and developing economies as a whole, it could well play a prominent role in the evolution of labor shares in specific economies, such as those where the labor share of income has risen.

Participation in global value chains: Figure 6 (panel 3) illustrates the rising trend in global value chain participation - measured as the sum of so-called forward and backward linkages in vertical specialization, a widely-used measure of participation in global value chains. ${ }^{24}$ Among advanced economies, this reflects an offshoring of production of

\footnotetext{
${ }^{22}$ Hsieh and Klenow (2007) document the higher level of the relative price of investment in poor countries. Some evidence in Obstfeld and Taylor 2004 suggests that this is driven by distortions, including import barriers and taxes. Dao and others (forthcoming) find a strong negative correlation between the import price deflator and the relative price of consumption in emerging market economies, as well as in some commodity-intensive advanced economies, which is absent in other advanced economies. Factors that affect the level of the relative price of investment in emerging market economies could affect the trend change if the role of these factors has changed over time (see Dao and others, forthcoming).

${ }^{23}$ The initial exposure to routinization is measured as the first available observation between 1990 and 1995 . For further details, see Annex 3.

${ }^{24}$ Backward linkages capture the extent of offshoring intermediate inputs used in exports and are defined as the share of foreign value added in gross exports. Forward linkages measure the extent of vertical specialization and are defined as the share of exports consisting of intermediate inputs used by trading partners for production of their exports to third countries (Koopman, Wang, and Wei 2014).
} 
intermediate goods, and since the late 1990s a steady increase in offshoring of services as well (Amiti and Wei 2009). Among emerging market and developing economies, it reflects an increase in importing components for assembly and re-exportation in global value chains (Hummels and others 2014; Koopman, Wang, and Wei 2014). ${ }^{25}$

An important insight in modern trade literature is that most trade flows occur within narrowly defined industries and that the production of a final good is often broken up into a set of tasks that can each be carried out in the most cost-efficient location (Grossman and Rossi-Hansberg 2008). This paper presents a mechanism by which the expansion of global value chains has the potential to account for a decline in labor shares in both advanced and emerging market and developing economies. The mechanism described here is one of many possibilities but is supported by a key stylized fact about global value chain participation and capital deepening. A sketch of the main elements of this mechanism is presented below (Annex 2 presents the details).

The expansion of global value chains has been enabled by a collapse in the costs of communication and transportation, which has allowed firms to unbundle production into many tasks and minimize production costs by exploiting factor cost disparities across countries (Feenstra and Hanson 1997; Grossman and Rossi-Hansberg 2008). Because wages are higher in advanced economies than in emerging market and developing economies, tasks that are relatively labor-intensive are likely to be offshored from the former to the latter. For advanced economies, the implications are straightforward: because offshored tasks are relatively labor-intensive, the composition of production becomes more capital-intensive, and a decline in labor income shares ensues. In addition, offshoring - or the threat thereoflowers labor's bargaining power (Harrison 2002), further reducing the labor share within remaining tasks.

To consider how participation in global value chains can also reduce labor income shares in emerging market and developing economies, a preliminary observation is that the expansion of global value chains has coincided with the steep decline in the relative price of investment goods in advanced economies, leading to automation of more tasks in these economies. In particular, tasks most likely to be automated are those for which labor is most substitutable by capital, thus implying that tasks with low elasticity of substitution between capital and labor are most likely to be offshored. ${ }^{26}$ The key insight of the stylized model is that insofar as tasks offshored have limited substitution between capital and labor, participation in global value chains can also reduce labor income shares in emerging market

\footnotetext{
${ }^{25}$ For simplicity of exposition, the paper assumes that advanced economies' participation in global value chains mostly entails offshoring of labor-intensive jobs to lower wage destinations (and specialization in high-skill tasks at either end of the value chain), and that emerging markets' participation in global value chains reflects mostly onshoring of such jobs for assembly and re-exportation. This is an obvious simplification because a country can specialize along different stages of the global production chain at the same time, producing along several parts of a value-added chain that entail both offshoring and onshoring (Hummels and others 2012).

${ }^{26}$ This intuition is formally proved in Proposition 1 in Annex 3.2.
} 
and developing economies

The crucial mechanism is that in an environment of high local relative cost of capital - as would be the case in capital-scarce emerging market economies - tasks with high substitutability between factors will have lower capital shares than the average task, as firms exploit low relative labor costs to substitute labor for capital. Symmetrically, tasks with low substitutability between capital and labor will have high capital shares. It follows that by raising the proportion of tasks for which it is difficult to replace capital by labor, offshoring can shift the composition of production to tasks with higher capital shares, thus lowering the average labor income share in receiving countries.

Elsby, Hobijn, and Şahin (2013) hypothesize that one way to rationalize declining labor shares worldwide is to consider that tasks that are labor-intensive in advanced economies are capital-intensive compared with existing tasks in the economies to which they are
Figure 8. Changes in Global Value Chain Participation and Capital Intensity

Rising participation in global value chains is associated with increasing capital intensity in production, particularly in emerging market and developing economies.
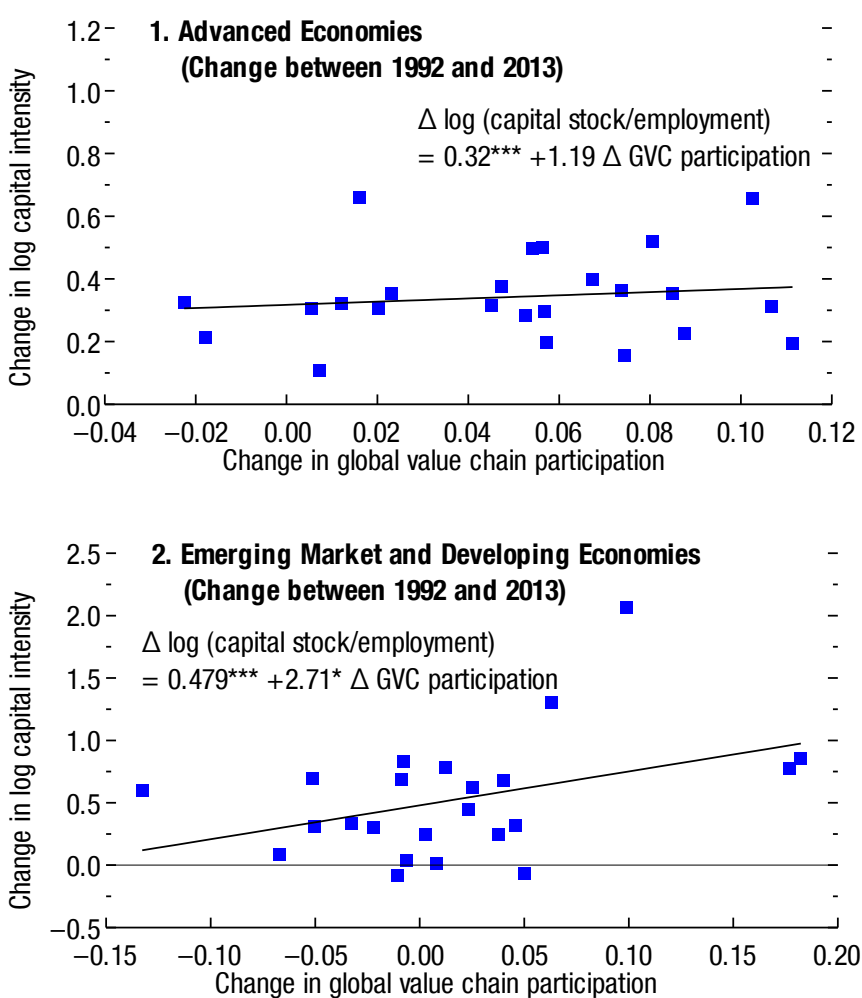

Sources: Eora Multi-Region Input-Output database; Penn World Table 9.0 database; and IMF staff calculations.

Note: Change in capital intensity refers to the change in log (capital stock/employment); change in global value chain participation is measured using the backward linkage - that is, the share of foreign value added in gross exports. GVC = global value chain.

offshored, which would raise capital shares in both sending and receiving economies. ${ }^{27}$ This idea resembles that in Feenstra and Hanson (1997), in which low-skill tasks offshored from advanced economies are nevertheless relatively high-skill tasks in recipient emerging market economies. By clarifying the nature of tasks likely to be offshored, the mechanism proposed

\footnotetext{
${ }^{27} \mathrm{~A}$ related hypothesis is in Cho 2016, in which technological advancement is always labor saving, and tasks that are relatively more labor intensive in advanced economies are offshored to emerging market economies. In that case, offshoring lowers labor shares in emerging markets because offshored tasks use more advanced technology than existing technology. In contrast with Cho 2016, in this paper's model, technological advancement may or may not be labor saving to allow for the possibility that high-skilled workers in emerging markets benefit more from technological advancement but are also highly complementary with capital.
} 
in this paper provides a conceptual foundation for the hypothesis in Elsby, Hobijn, and Şahin 2013.

The model of this paper is intended to illustrate a mechanism that can relate global value chain participation to the observed decline in labor shares worldwide. The model contains some assumptions - for instance on the parameters of the task-specific production function. Whether participation in global value chains lowers or raises overall labor shares is thus ultimately an empirical question. The stylized evidence in Figure 8, however (examined more systematically in the following section), suggests that rising global value chain participation is indeed associated with rising capital intensity, particularly in emerging market and developing economies.

Financial integration: Fewer barriers to the mobility of capital, particularly to foreign direct investment, across borders may also play a role in labor share dynamics. This may happen through two distinct channels. First, by facilitating the relocation of production to countries with cheaper inputs, capital mobility lowers labor's bargaining position. ${ }^{28}$ Second, by increasing access to capital, financial integration lowers the cost of capital in capitalscarce countries, facilitating capital deepening and potentially inducing greater substitution of capital for labor. ${ }^{29}$ The second channel may be especially relevant for emerging market and developing economies where financial frictions and credit rationing are more prevalent, and the benefits of financial integration accrue largely to high-skilled workers, whose skills are more complementary to capital. ${ }^{30}$

Policies, institutions, and regulations: Labor and product market policies, institutions, and regulations can also play a role in the evolution of labor shares. While policies themselves may have changed partly in response to trends in global integration and technology, these changes may also have had independent impacts on labor income shares. A decline in corporate income tax rates, for instance, can raise the relative return to capital, which may induce a further substitution of capital for labor and lower the labor share of income. The trend decline in unionization rates may reflect the lower bargaining power of labor (Figure 6, panel 4), also causing a decline in labor income shares. Moreover, changes in market regulations over the past two decades - for example, those that regulate worker hiring and dismissal or competition in product markets - may have affected factor shares through their impact on the size and distribution of rents. Changes in product market structure could also emerge independently of regulation and may reflect, for example, technological

\footnotetext{
${ }^{28}$ Kramarz (2016) discusses this channel and provides supporting empirical evidence using firm-level data.

${ }^{29} \mathrm{Net}$ foreign direct investment flows have indeed gone from rich to poor countries despite the Lucas paradox (the assertion that total capital flows from rich to poor countries are far lower than predicted by theory). Caselli and Feyrer (2007) show that the net return differential between rich and poor countries is not as large as originally assumed; for a updated overview see Boz, Cubeddu and Obstfeld (2017).

${ }^{30}$ See Berman, Bound, and Griliches 1994; and Jaumotte, Lall, and Papageorgiou (2013).
} 
advances and the integration of global product markets that result in a rising concentration of industries. Autor and others (2017) describe a "winner-take-most" dynamic to explain rising profit shares, and consequent declining labor shares, across industries.

Measurement: Two important measurement challenges could account for some of the apparent decline in labor shares. The first has to do with the labor income of the selfemployed, which is imputed for the purposes of reporting a headline figure in national accounts. The second concerns the depreciation of capital, which should arguably be discarded from the calculation of factor income shares since it cannot be consumed by either workers or capital owners. ${ }^{31}$ Adjustments for self-employment and depreciation would in general raise the level of the labor share. However, these measurement issues could also affect the evolution of labor shares over time. For instance, all else equal, falling self-employment rates would make the labor share decline steeper, while rising capital depreciation rates would make the decline less pronounced. Given data limitations, this paper treats measurement issues as a fourth factor in explaining the evolution and cross-country comparison of labor shares and reports the robustness of results to different measures of the labor share of income (Figure 9).

\section{Figure 9. Evolution of the Adjusted Labor Share of Income \\ (Percent)}

Adjustment of the labor share of income for self-employment and capital depreciation results in level changes as well as changes in the trend of the labor share. The level shift of self-employment adjustment is larger in emerging markets and developing economies while that of capital depreciation adjustment is larger in advanced economies.

— Unadjusted labor share

— Self-employment adjusted labor share

_ Self-employment and depreciation adjusted labor share
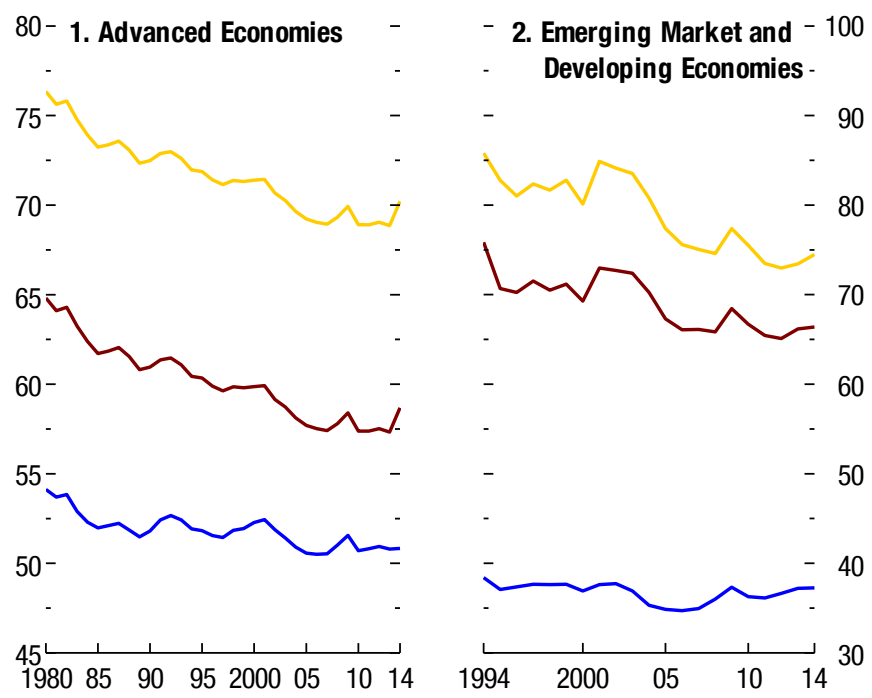

Sources: Karabarbounis and Neiman (2014); national authorities; Organisation for Economic Co-operation and Development; World Bank, World Development Indicators database; and IMF staff calculations.

Note: Both panels show year fixed effects from regressions that also include country fixed effects to account for entry and exit during the sample. The regressions are weighted by nominal GDP in current U.S. dollars. Fixed effects are normalized to reflect the level of the labor share in 2000.

In summary, the factors discussed so far can affect labor shares differentially in different country groups. Furthermore, different facets of globalization-such as participation in global value chains and financial integration - may have offsetting or

\footnotetext{
${ }^{31}$ Recent work by Rognlie (2015) has emphasized this second factor, noting that the net capital share has risen more modestly than the gross capital share in the United States and that the labor share has thus declined less than commonly reported.
} 
reinforcing impacts. Assessing their relative contributions to labor share trends is thus ultimately an empirical exercise.

\section{Analyzing Trends in the Labor Share of InCome: Empirical Analysis}

The analysis begins with a shift-share analysis and empirically quantifies how much of the global decline in labor shares is attributable to decreases within industries and how much to compositional changes - that is, a reallocation of labor between industries, from those with higher to those with lower labor shares. This exercise is an important first step for two reasons. First, it is an essential tool to gauge the role of structural transformation-for example, from manufacturing to services in advanced economies and from agriculture to manufacturing and services in emerging market economies - in the decline in labor shares. Classical trade theory, for example, predicts a shift toward capital-intensive industries in capital-abundant advanced economies (resulting in lower labor shares) and a shift toward labor-intensive industries in labor-abundant emerging market economies (resulting in rising labor shares). Second, the shift-share analysis can then determine whether it would be more useful to study within-industry changes in labor shares or those arising from reallocation of resources between industries.

\section{A. Shift-Share Analysis}

The shift-share analysis is performed on a sample of 27 advanced economies and 13 emerging market and developing economies across 10 one-digit industries (International Standard Industrial Classification), decomposing the trend changes in labor shares into their within-industry and between-industry components. ${ }^{32}$ The results of this exercise are shown in Figure 10 (panel 1), which plots the total trend change on the horizontal axis against the within component on the vertical axis.

The shift-share analysis suggests that the reallocation of factors across broad industrial categories has generally not been a significant driver of labor share trends. Most countries are clustered around the 45-degree line, indicating that trend changes in labor shares emerge overwhelmingly from trend changes in within-industry labor shares rather than from the reallocation of factors across industries. Indeed, the within component is found to account for more than 90 percent of the total trend change. An important exception is China, ${ }^{33}$ where reallocation from industries with relatively high labor shares, most notably agriculture, to expanding industries with lower labor shares, such as wholesale trade and transportation and communication, accounts for some 60 percent of the total decline in the labor share

\footnotetext{
${ }^{32}$ The total change is decomposed for each yearly change as $\Delta L S_{i, t}=\sum_{k=1}^{n}\left(w_{i, k, t-1} \Delta L S_{i, k, t}\right)+\sum_{k=1}^{n}\left(\Delta w_{i, k, t} L S_{i, k, t-1}\right)$ (where the first sum is the within change and the second is the between change), and summed overall years in the sample.

${ }^{33}$ For a further analysis of the evolution of labor shares in China see Dao and others (forthcoming).
} 
during 1991-2014. ${ }^{34}$ Similar findings are obtained when the analysis is performed for 22 Organization for Economic Co-operation and Development economies using more disaggregated (two-digit level) data covering 31 sectors (Figure 10, panel $2)$. Although many countries in the sample now deviate a little farther from the 45-degree line, they typically lie below the line, indicating that factor reallocation between industries has often tended to increase labor shares in advanced economies. These findings do not provide much support for the predictions of traditional trade theory and suggest that it would be useful instead to study the drivers of within-industry changes to understand overall trends in labor shares. ${ }^{35}$ The empirical analysis turns to these drivers next, starting with an exploration of country-level data, then moving to country-sector data and finally to country-sector data by skill level.

\section{B. Analysis of Long-Term Changes in the Aggregate Labor Share of Income}

\section{Figure 10. Shift-Share Analysis}

More than 90 percent of variation in labor share trends across countries is explained by within one-digit sector variation, and over 70 percent by within two-digit sector variation. The role of between-sector reallocation often associated with structural transformation is small on average, but plays a dominant role in China.
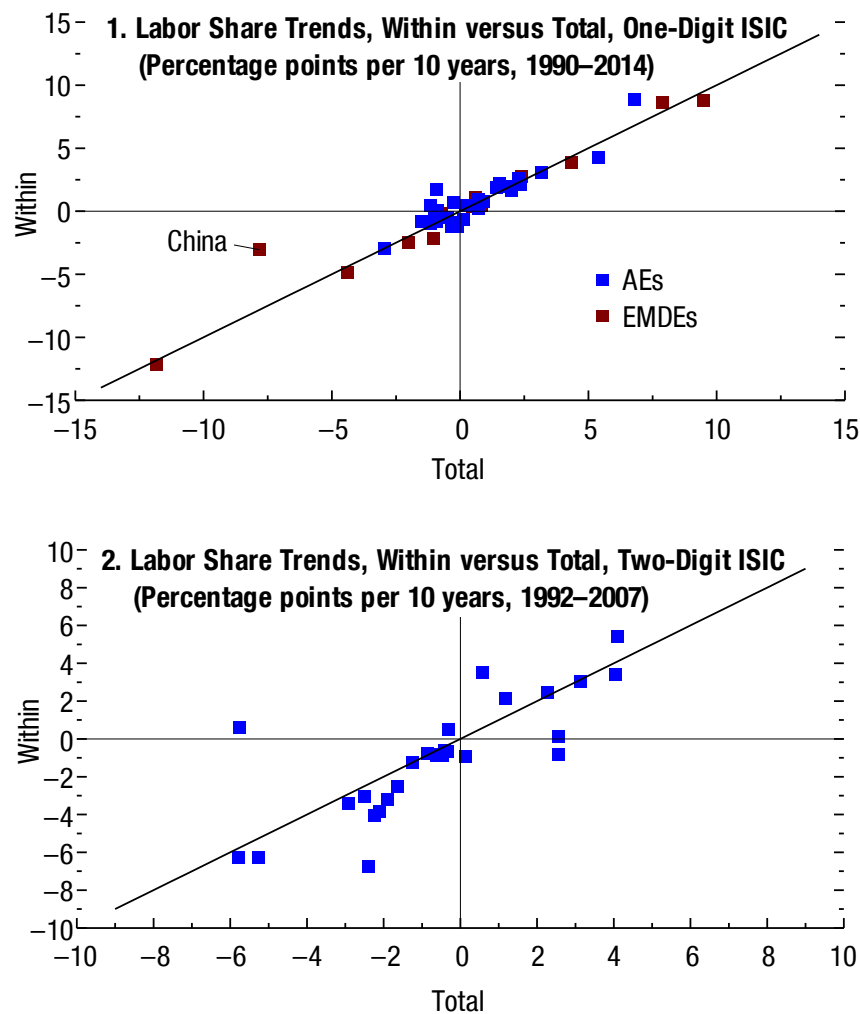

Sources: CEIC database; Organisation for Economic Co-operation and Development database; World Input-Output Database; and IMF staff calculations.

Note: $\mathrm{AEs}=$ advanced economies; EMDEs = emerging market and developing economies; ISIC = International Standard Industrial Classification of all Economic Activities, Revision 4.

To assess the contributions of the key drivers of labor income shares, this section

\footnotetext{
${ }^{34}$ This finding contrasts with that of Karabarbounis and Neiman 2014, reflecting both a slightly different timeframe in this paper's analysis and, importantly, nontrivial revisions to China's labor share data in official sources.

${ }^{35}$ Shift-share analyses have well-known limitations. Two possible limitations in the exercise here are that the shift-share decomposition does not take account of structural changes in the nature of industry, for example, the surge in internet commerce in the retail sector. Furthermore, while the decomposition at the two-digit level is useful to consider the possibility of between-sector shifts within one-digit sectors, the two-digit industrial groups are arguably still fairly aggregated.
} 
examines the empirical relationship between trends in labor shares and technology, global integration, and other factors. Following influential work on the analysis of labor shares, the approach focuses on long-term changes in labor shares and relates them to long-term changes in potential drivers. ${ }^{36}$ This strategy is motivated by important considerations, including the long time horizons of adjustments to structural changes triggered by technological advances and global integration, and the lower likelihood of being biased by cyclical or temporary conditions that have little implication for long-term changes in labor shares. Measuring longterm changes in drivers of labor shares, such as financial integration, allows for better capturing country-specific fundamentals as opposed to high-frequency movements triggered by cyclical or temporary conditions. ${ }^{37}$

Limiting the analysis to countries that have at least 10 years of data over the 19912014 period, the regression model is estimated on a sample of 49 countries (31 advanced economies and 18 emerging market economies). The baseline estimation equation of the aggregate regression is:

$$
\widehat{L S}_{c}=\alpha+\beta_{2} \widehat{P I}_{c}+\left[\beta_{3} R T I_{0, c}+\beta_{4} R T I_{0, c} \widehat{P I}_{c}\right]+\beta_{1} \widehat{G}_{c}+\beta_{5}{ }^{\prime} \widehat{P o l}_{c}+\varepsilon_{c}
$$

in which (hat) variables are long-term annualized changes during 1991-2014 at the country level. A similar approach was used by Karabarbounis and Neiman (2014); Elsby, Hobijn, and Şahin (2013); and Acemoglu and Restrepo (2016). To estimate the effect of technology, the analysis follows Karabarbounis and Neiman (2014) by using the change in the relative price of investment goods to proxy firms' incentives for capital-labor substitution. Furthermore, an important innovation of the paper is the recognition that such substitution will be stronger in countries that are initially more exposed to routinization. By measuring exposure to routinization for each country at the start of the time period, the paper's approach mitigates concerns that high initial exposure to routinizable jobs will itself lead to greater adoption of routine technology and thereby lower subsequent exposure to routinizability. PI denotes the relative price of investment (relative to consumption) goods, and $R T I_{0}$ the initial exposure to routinization. $G$ subsumes variables measuring the evolution of globalization: changes in total goods trade (value-added exports and non-oil imports in percent of GDP), as well as trade in intermediate goods and global value chain participation (measured alternatively by the sum of forward and backward linkages as defined in the text, or by imported intermediate inputs in percent of gross value added), and changes in financial globalization (external

\footnotetext{
${ }^{36}$ See, for example, Harrison 2002; Rodrigues and Jayadev 2010; Elsby, Hobijn, and Şahin 2013; Karabarbounis and Neiman 2014; and Acemoglu and Restrepo 2016.

${ }^{37}$ All regressions allow for capital and labor to adjust freely in response to changes in their relative costs over the long term. Therefore, controlling for the relative price of investment goods not only captures the immediate demand effect, but also any potentially offsetting adjustment from changes in relative factor supplies. Similarly, rising global value chain participation may trigger an endogenous response of capital and labor supply in addition to the immediate demand and composition effect.
} 
assets and liabilities, excluding international reserves in percent of GDP). The results consider alternative measures for both the technology and global integration variables to assess robustness of the results. ${ }^{38}$ Further details on variable construction and sources are given in Annex 3.

Variables in Pol summarizes policy and institutional factors, including changes in union density, corporate taxation, employment protection legislation, and product market reforms over the sample period. ${ }^{39}$ To assess whether reforms to the regulation of product and labor markets during 1991-2014 have affected labor shares, the regressions include an indicator for countries that enacted significant reforms in deregulating employment protections and product markets. Indicators for labor market and product market reforms were developed using the Fraser Institute's Economic Freedom of the World data set, specifically based on the indicators "hiring and firing regulations" and "business regulations" between 1995 and 2014. ${ }^{40}$ To identify major regulation or deregulation efforts for each country, ordinal scaled variables are assigned the value 1 (describing major deregulations) in every year the change in the index is larger than the country-specific mean plus one standard deviation. The value -1 (describing major regulations) is assigned where the change in the index is larger than the country-specific mean minus one standard deviation; the indicator is otherwise zero. Some individual indicators may be vulnerable to perception-based rankings and measurement uncertainties. However, by combining data from several sources - the Fraser Institute's indicators are constructed using, among others, data from the World Bank, World Economic Forum and the International Institute for Management Development World Competitiveness data - the constructed indices potentially have more comprehensive data coverage than a single indicator and may also be less sensitive to outliers and concerns about subjectivity. Due to a structural break in the series in 2001, separate means and standard deviations are calculated (for each country) in the two series.

Table 3 summarizes the baseline aggregate regression results. Columns 1 to 4 present the estimates block by block, column 5 estimates all drivers jointly, and column 6 interacts the variables that are statistically significantly different between advanced economies and emerging market economies, with an advanced economy dummy. Regarding the role of technology, the empirical estimates imply that a decline of 15 percent in the relative price of investment goods (the average decline in the sample) leads to a 0.4 percentage point decline in

\footnotetext{
${ }^{38}$ These include, for example, a measure of intermediate imports excluding commodities as well as volumes of intermediate imports, in lieu of global value chain participation; gross stocks of inward and outward foreign direct investment for financial integration; and a measure of the user cost of capital in lieu of the price of investment goods. Additional robustness checks are described in Annex 3.4.

${ }^{39}$ Corporate tax rates are measured using basic central government statutory (flat or top marginal) corporate income tax rates.

${ }^{40}$ For details, see Gwartney, Lawson, and Hall (2016).
} 
the labor share in a country with relatively low initial exposure to routinization, and about a 1.5 percentage point decline in a country with high exposure to routinization. ${ }^{41,42}$ As for globalization, while overall trade in goods and services does not appear to matter much for labor shares, participation in global value chains does. Participation in global value chains is estimated to have exerted a strong negative effect on the labor share of income in both advanced economies and emerging markets, supporting the notion that offshored tasks are labor-intensive for the former group of countries but raise capital intensity in the latter. The empirical estimates indicate that an increase in intermediate goods imports of 4 percent of GDP (corresponding to the median increase in global value chain integration in the sample) is associated with a 1.6 percentage point decline in the aggregate labor share, on average, with a significantly larger impact in emerging markets. ${ }^{43}$ International financial integration has contrasting effects on the two country groups, depressing labor shares in advanced economies while raising them in emerging markets. It has long been argued that rising capital mobility increases the bargaining power of capital relative to that of labor by facilitating the relocation of production. ${ }^{44}$ The empirical estimates are consistent with this notion for advanced economies, which are, in general, the source countries of cross-border capital flows. The finding for emerging markets, on the other hand, is consistent with the notion that capital inflows lower the cost of capital and, so long as production has limited substitutability of capital for labor (the elasticity of substitution is lower than one), raises the labor share of income. Consistent with the evidence in Jaumotte, Lall, and Papageorgiou (2013), the impact in emerging market economies is likely driven by raising the labor income share of highskilled workers.

The measures of trend changes in labor and product market regulation, as well as changes in corporate taxation, are not found to have robust effects on labor share trends over the sample period. Declines in corporate income taxation do appear to have a strong bivariate correlation with the trend changes in labor shares, but these are not estimated to be statistically significant in a richer setting that controls for the strong contemporaneous trends

\footnotetext{
${ }^{41}$ High exposure refers to those economies whose initial exposure to routinization is at the 75 th percentile of the distribution of exposures, while low exposure refers to those where the initial exposure is at the 25 th percentile.

${ }^{42}$ The finding that about half of the decline in labor shares is traceable to technology is consistent with Karabarbounis and Neiman 2014.

${ }^{43}$ The smaller impact of offshoring in advanced economies may reflect the reallocation of displaced workers in advanced economies from manufacturing to low-skill (but labor-intensive) service industries, which may itself raise the labor share and work against the negative impact of offshoring on labor shares. In emerging market economies, the impact on labor shares due to reallocation from labor- to more capital-intensive jobs is more straightforward. Another possible reason for the smaller impact of offshoring in advanced economies is that imported intermediate inputs may raise the labor share in some tasks or sectors through their positive effect on productivity, if such tasks have a relatively low elasticity of substitution.

${ }^{44}$ See Harrison (2002), and Jaumotte and Tytell (2007).
} 
in globalization and technological progress.

The empirical model closely tracks changes in labor shares during 1991-2014 across countries, and strongly confirms the significant roles played by technological advancement, exposure to routinization, and global integration in the decline in labor shares (Figure 11, panel 1). One notable outlier is China, where - consistent with the findings of the shift-share analysis - a significant change in industrial composition has contributed to the decline in the labor share. Another outlier is South Africa, where a substantial increase in financial integration is the key contribution to the predicted rise in labor share, while in fact much of the crossborder financial flows has been driven by extractive industries and thus is not likely to contribute as much to higher wages and labor share as in other emerging markets. With the caveat that it is difficult to cleanly separate the impacts of technology from global integration, or from policies and reforms,
Figure 11. Aggregate Results

The empirical model explains about two-thirds of the evolution of aggregate labor share trends across countries, with China and South Africa being two important outliers. In AEs, technology contributes to about half the variation in labor share declines across countries, with GVC participation and financial integration accounting for one quarter. In EMs, GVC participation is the dominant factor for labor share declines, offset by the positive effect of financial integration, while technology plays a much smaller role.
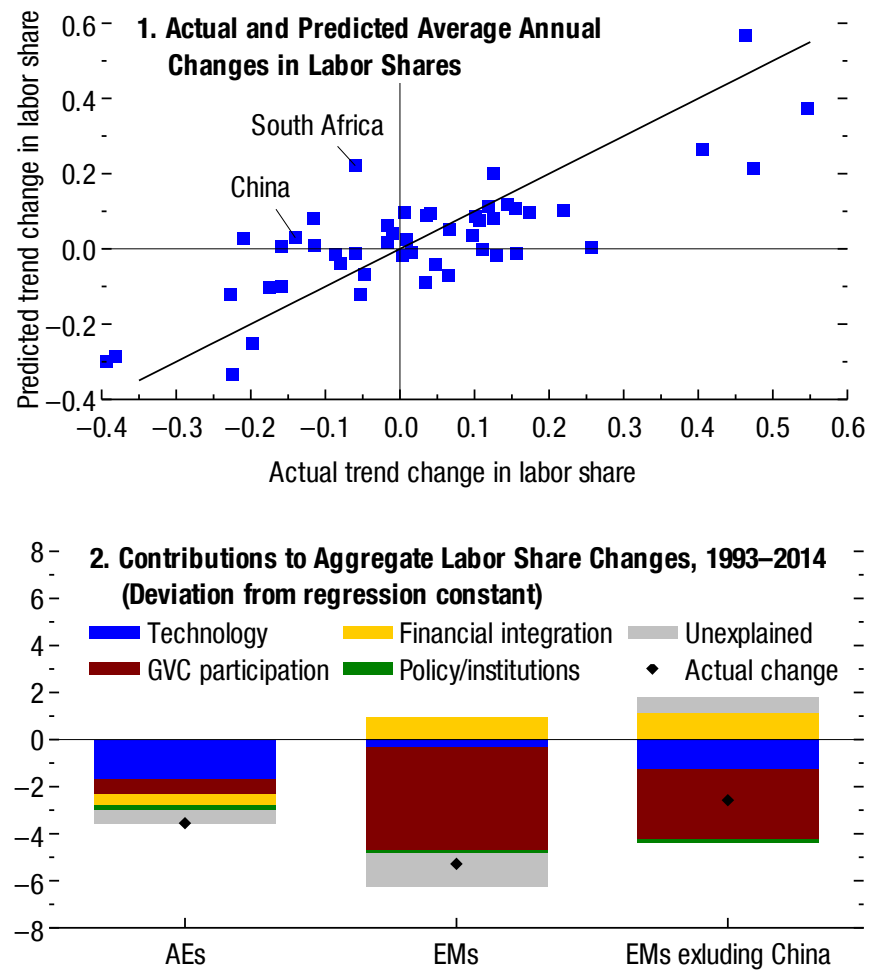

Source: IMF staff calculations.

Note: Panel 1 shows actual average annual changes in labor shares for countries with at least 10 years of data and predictions based on the aggregate trend regression model (see Annex 3.3). Derived contributions are scaled to show total changes over 25 years. AEs = advanced economies; EMs $=$ emerging markets; GVC = global value chain .

Figure 11 (panel 2) presents a decomposition into these various factors to gauge their relative contributions to changes in labor shares. In advanced economies as a whole, technology, proxied by the declining relative price of investment goods and the initial exposure to routinization, has been the largest contributor to the decline in labor shares, accounting for almost half of the overall decline. Global integration - in particular, participation in global value chains and financial integration - is estimated to have contributed about half as much as technology.

The results for advanced economies as a group generally also hold for individual economies. For example, the joint negative effect of technology and global integration can explain roughly three-quarters of the decline in labor shares in Germany and Italy and more 
than half of the decline in the United States (all countries with relatively high exposure to routinization and, in the case of the United States and Germany, rising integration into global value chains). However, the increase in labor share in the United Kingdom, though modest, fails to conform to this general pattern. Finland and Norway, on the other hand, are examples of countries that had low exposure to routinization and, as predicted by the empirical analysis, experienced a trend increase in labor shares.

For emerging market and developing economies, the forces of global integration have had large but partially offsetting effects, with participation in global value chains lowering the labor share of income and financial integration raising it. Technology has played a very small role in the aggregate, but its impact on labor shares is heterogeneous across individual countries. Furthermore, there is more variation in the relative contribution of different drivers to labor share trends across the sample of emerging markets than in advanced economies. For example, the increase in the relative price of investment goods, together with financial integration, explain about half of the trend rise in labor share in Brazil, while participation in global value chains plays a negligible role. In Turkey, by contrast, the decline in labor share is explained almost exclusively by the rapid rise in its participation in global value chains, while technology plays a limited role, reflecting in particular its very low exposure to routinization.

\section{Robustness of Aggregate-Level Regression Results}

Stacked regressions. The baseline aggregate regressions collapse observations of each variables into long-differences over the entire sample period for each country and hence result in a set of cross-section regressions whose sample size is limited by the number of countries. We explore whether results are maintained when sample size is augmented by computing 5-year differences (instead of long 15 year differences) instead and stacking several such differences for each country. Table 4 summarizes the results of the stackeddifferences estimation according to the following regression equation:

$\widehat{L S}_{c, t}=\alpha+\beta_{2} \widehat{P I}_{c t}+\left[\beta_{3} R T I_{0, c t}+\beta_{4} R T I_{0, c t} \widehat{P I}_{c t}\right]+\beta_{1}{ }^{\prime} \widehat{G}_{c t}+\beta_{5}{ }^{\prime} \widehat{P o l}_{c t}+\gamma F E_{c}+\delta F E_{t}+\varepsilon_{c t}$

in which all variables are defined as in the baseline aggregate regression equation, but with $t$ denoting nonoverlapping consecutive five-year periods $(t=1992-96,1997-2001,2002-06$, 2007-11, depending on country), stacked for each country $c$. The panel structure makes it possible to control for country-specific trends and period-specific unobservables, while significantly increasing the number of observations compared with the baseline crosssectional trend regression. However, a drawback of the stacked regression is that it loses some of the trend changes that are discernible only over a longer horizon (more than five years) and that cyclical and temporary factors are not completely purged.

Given that the variables are formulated as annualized changes, they can be directly compared with the baseline long-term trend regressions. Results of the stacked-differences 
regression in Table 4 strongly confirm findings in the baseline. The impact of technology is similar in magnitude, but less precisely estimated, arguably because adjustments to technological change materialize only over a longer time horizon. That said, the effect of global value chain participation is very similar to the trend results, implying a faster adjustment to globalization forces than to technology. The effect of employment protection legislation reforms is also statistically significantly negative for labor shares within five years of the reform. However, they are again swamped out by the impact of technology and trade in the joint specification.

Alternative measures of cost of capital. Table 5 examines robustness with respect to alternative measures of the relative cost of capital. In column 1, the baseline regression is first rerun using the smaller sample for which sufficiently long time series of user cost of capital data can be obtained. In column 2 , instead of using only relative $P I$, the comprehensive measure of user cost of capital (UCC) is derived from the steady state of the Euler equation of the model to be:

$$
U C C=P I^{*}(\text { real } I R+\text { depreciation rate })
$$

in which the real interest rate $(I R)$ is computed using long-term (10-year) government bond yields deflated by long-term inflation expectations, which can be constructed for sufficiently long periods for a subsample of 40 countries. Column 3 adds further baseline control variables. Column 4 controls for trends in financial deepening directly by adding trends in private credit as a share of GDP. Results imply that the comprehensive measure of UCC affects labor shares similarly to the price of investment, though the result is less significant, possibly because more measurement error is introduced with the additional variables (especially depreciation rates). Accounting for general financial deepening actually raises the labor share, a result that is driven mostly by the emerging market economies sample. This is consistent with the finding that the average elasticity of substitution is lower than 1 in this country group, because financial and capital deepening would, on net, boost wages and labor shares in such an environment. In all cases, the effect of participation in global value chains remains significantly negative and of similar magnitude as in the baseline estimate.

Alternative measures of offshoring exposure. Table 6 examines robustness with respect to alternative measures of trends in offshoring. First, intermediate imported input share (in percent of GDP) is used instead of global value chain participation (column 1). Second, to rule out the possibility that the effect of offshoring is driven by generally more complex production that is also manifested in a higher share of total intermediate use, column 2 controls instead for the share of imported intermediate goods in total intermediate goods used. Third, to rule out the possibility that results are driven by long-term swings in commodity prices, intermediate import shares are computed excluding commodities for a 
subsample of countries that have data on intermediate imports by detailed product categories (column 3). Finally, column 4 measures intrinsic or de jure trends in offshoring by interacting the initial offshorability index computed from microlevel occupation data with the trend in the import price index for each country. All results confirm that globalization in intermediate trade has negatively affected labor shares.

Other robustness. Table 7 summarizes further robustness results. Column 1 repeats the baseline trend regression using robust regression instead of ordinary least squares - that is, dropping gross outlier countries and using a Huber iteration algorithm to estimate coefficients by assigning different weights to countries. Column 2 repeats the baseline regression by weighting countries by their average GDP (in purchasing power parity) over the sample period. Column 3 excludes transition economies. Column 4 includes additional covariates: trends in demographics (old-age dependency ratio) and the trend change in migrant stocks and human capital (relative high-skill supply) as well as initial GDP per capita. Column 5 ends the sample period in 2007 to exclude the impact of the global financial crisis. Finally, Table 8 presents the results' robustness when using labor share data adjusted for self-employment and capital depreciation (for details on construction of the adjusted labor share data, see IMF, 2017b). The impact of the main drivers of labor share trends in the cross-section of countries is largely preserved both in sign and magnitude.

\section{Analysis of Long-Term Changes in Sectoral Labor Shares}

This section complements the analysis of aggregate labor shares by analyzing their changes across countries and industries. Given data limitations, the sample is restricted to 27 advanced economies for which country-sector data are available for at least 10 years. As noted earlier, while the global labor share of income has been on a declining trend since the 1980s, this aggregate picture conceals considerable heterogeneity across industries (Figure 12, panels 1 and 2). However, even within given industries, there are meaningful cross-country differences. For example, in manufacturing, which saw large declines on average, labor shares fell in only about two-thirds of the countries (Figure 12, panel 3).

The sectoral analysis explores this additional heterogeneity. While results from the analysis of aggregate labor shares shed light on the contributions of drivers to overall labor shares, where those estimated contributions are small, they may reflect large offsetting contributions across sectors. For example, the apparently small impact of participation in global value chains on aggregate labor shares in advanced economies could be concealing a large negative impact in tradables sectors that is potentially offset by a positive impact in nontradables sectors. In such cases, it is important to qualify the aggregate results with a more nuanced interpretation of the contribution of specific drivers. 
The sectoral analysis is potentially also more robust to concerns that drivers are correlated with unobserved country- or sectorspecific factors that could not be accounted for in the country-level analysis (see Annex 3 for definitions of variables and sources). The sectoral results can also help clearly test for hypotheses that vary along the sectoral dimension, such as the role of trade and participation in global value chains, which should be found to be greater in tradables than in nontradables. It is also important, however, to underscore some limitations of sectoral analysis, including smaller country coverage, and a shorter time series (see Table 1 for the list of countries included in the sectoral analysis). Results should thus be seen as complementing the aggregate findings.

The empirical strategy at the sectoral level closely follows that used at the aggregate level, examining the effects of long-term changes in technology and globalization on long-term changes in labor shares. The following cross-sectional regressions are estimated at the country-sector level:

$$
\widehat{L S}_{c S}=\beta_{1}^{\prime} \widehat{G}_{c S}+\beta_{2} \widehat{P I}_{c S}+\left[\beta_{3} R T I_{0, c s}+\beta_{4} R T I_{0, c s} \widehat{P I}_{c S}\right]+\gamma_{0}^{\prime} F E_{c}+\gamma_{1}^{\prime} F E_{s}+\varepsilon_{c s}
$$

relating long-term changes (denoted using hats) in sectoral labor shares $(L S)$ to long-term changes in globalization ( $G$, including total, intermediate trade and financial integration) and long-term changes in sectoral relative prices of investment $(P I)$ and their interactions with sectoral routinization scores $\left(R T I_{0}\right)$. Country and sector fixed effects are included to account for unobservable country- and sector-specific trends. Table 9 provides the regression results underlying Figure 13, highlighting differences between tradables and non-tradables sectors. 
As in the aggregate analysis, a model incorporating the effects of trade and technology can explain observed changes in labor shares reasonably well (Figure 13, panel 1). Bearing in mind that these factors are interrelated, a simple decomposition based on the sectoral analysis confirms the large role of technology in advanced economies (Figure 13, panel 2, and Table 9).

Declines in the relative price of investment have been associated with declines in labor shares, more so for sectors with higher initial exposures to routinization. For instance, in line with actual changes in labor shares, the model predicts relatively large declines in labor shares in manufacturing, mining and quarrying, and transportation (sectors with high initial levels of routinization), but it predicts increases in agriculture and wholesale and retail trade (sectors with low initial exposure to routinization).

The median decline in the
Figure 13. Sectoral Results, Advanced Economies

Increasing participation in global value chains is associated with declines in labor shares only in tradables sectors.
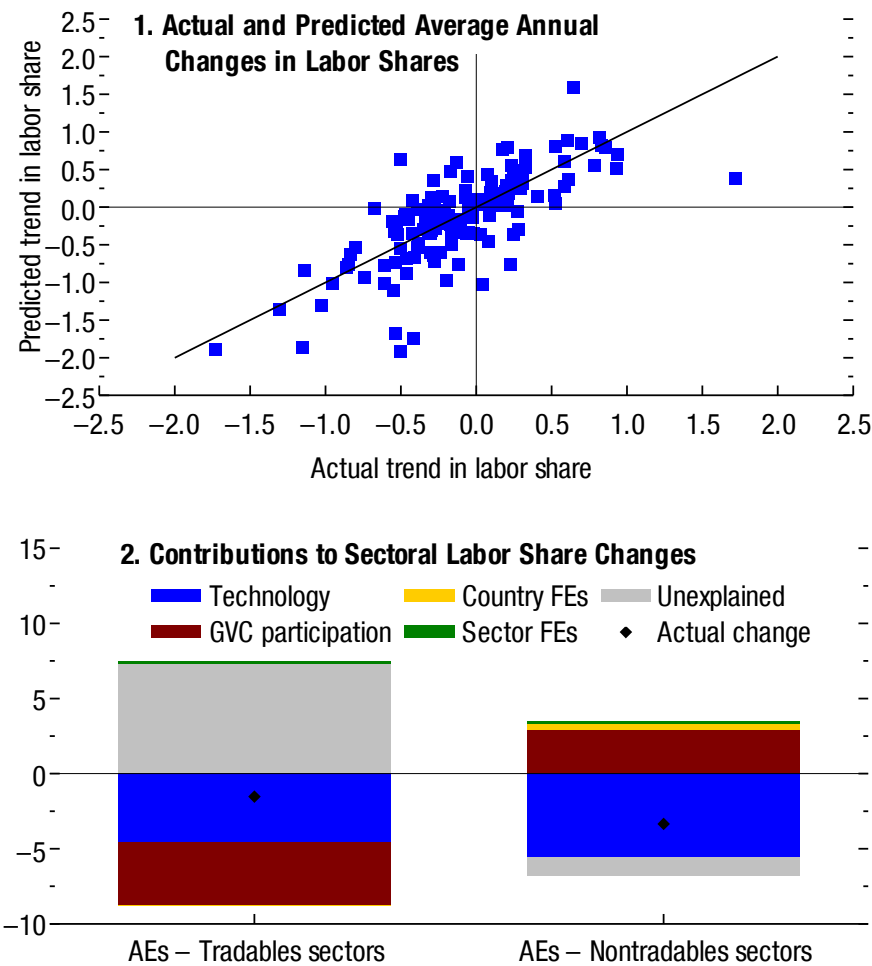

Source: IMF staff calculations.

Note: Panel 1 shows actual average annual changes in labor shares for country-sectors with at least 10 years of data, and predictions based on trend on trend regressions of sectoral labor shares on the price of investment, initial routine exposures, their interaction, and GVC participation. Contributions are based on trend regressions for country-sectors with at least 10 years of data and are scaled to show total changes over 25 years. FE = fixed effects; GVC $=$ global value chain

price of investment would predict a labor share decline that roughly corresponds to the observed decline in a country sector with a low exposure to routinization. ${ }^{45}$ This, for example, matches the pattern observed in restaurants and hotels in the United States. The effect of a decline in the price of investment has roughly double that effect on a country sector highly exposed to routinization. This in turn matches the experience of the manufacturing sector in Italy. Furthermore, in the cross-section, the predicted difference between the evolution of labor shares in restaurants and hotels, which are relatively less

\footnotetext{
${ }^{45}$ The median decline in the price of investment was about 15 percent over 25 years. This would predict a 1.8 percentage point decline in the labor share of a country sector at the 25th percentile of the distribution of routinization and an approximately 3.8 percentage point decline in the labor share of a country sector at the 75 th percentile of the distribution of routinization.
} 
routinizable, and the evolution of labor shares in manufacturing, which is much more at risk of automation, matches observed differences well. ${ }^{46}$

Trends in technological advancement, however, over-predict the overall decline in labor shares in advanced economies, with unobserved sector-level trends playing an important counterbalancing role. The model is thus estimated separately for the tradables and nontradables sectors to examine whether the relative roles of trade and technology differed. Increasing participation in global value chains is associated with declines in labor shares only in the tradables sectors. This is in line with the predictions of the model outlined earlier: as labor-intensive tasks are offshored, labor shares in tradables sectors are expected to decline as remaining production becomes more capital-intensive (Figure 13, panel 2, and Table 9). ${ }^{47}$

\section{E. Analysis of Long-Term Changes in Labor Shares by Skill}

This section turns to the analysis of labor shares of different skill levels. Due to data limitations, the sample of the analysis is also dominated by advanced economies. ${ }^{48}$ The goal is to examine the distributive effects of technology and trade, including whether these have contributed to polarization and the so-called hollowing out of the middle class in advanced economies. The approach is to analyze the evolution of the labor shares of high-, middle-, and low-skilled workers separately. ${ }^{49}$

Labor compensation by skill is constructed using the World Input-Output database's skill level labor compensation as a percent of total labor compensation, multiplied by labor compensation data, at the country and sector levels, respectively. Labor share by skill is then computed by taking the ratio of labor compensation by skill and value added, at both the country and sector levels.

As Figure 5, panel 1, indicated earlier, the labor income share of high-skilled workers

\footnotetext{
${ }^{46}$ The model predicts a 6 percentage point larger decline in labor shares in manufacturing (around the 75 th percentile of the distribution of routinization) than in restaurants and hotels (around the 25th percentile of the distribution of routinization); this is very similar to observed differences.

${ }^{47}$ Global value chain participation does not have a statistically significant effect on nontradables sectors. Here, the model's predictions are also more ambiguous and would depend on how these sectors are linked to the unbundled and offshored production processes.

${ }^{48}$ Aggregate analysis by skill focuses on a sample of 27 advanced economies and 10 emerging market economies, while sectoral analysis by skill is based on a sample of 27 advanced economies and 5 emerging market economies (Table 1).

${ }^{49}$ The definition of skill types is based on the level of education of workers. The World Input-Output database uses the 1997 International Standard Classification of Education (ISCED) to define low skilled as workers with primary and lower secondary education, middle skilled as those with upper secondary or postsecondary, nontertiary education, and high skilled as those with first-stage tertiary education or higher.
} 
has been increasing while that of middle- and low-skilled workers has been declining. ${ }^{50} \mathrm{~A}$ benign explanation for this evolution is that the rising skill premium has encouraged an upgrading of skills, resulting in higher relative supply of high-skilled labor and lower relative supply of middle- and low-skilled labor over time. This section studies whether, over and above this composition effect, the drivers of the overall labor income share have also contributed to this diverging evolution. ${ }^{51}$ The empirical strategy for the labor income share of different skill groups resembles that of the overall labor income share. It studies how long-term changes in drivers affect long-term changes in the labor income shares of each skill group, with the labor income share of a particular skill group defined as the labor compensation of that group divided by the aggregate value added of the country. In addition, as much of the diverging trends in skill-specific labor shares may reflect the changing skill composition of the labor force, the skill-level regressions additionally controls for skill composition (measured by educational attainment).

Table 10 provides the aggregate regression results by skill level while Figure 14 uses the regression results to decompose the actual change in labor share for each skill group to the different drivers. The results suggest that both technological advancement and participation in global value chains have lowered the income share of middle-skilled workers but have had little discernible effect on those of low- or high-skilled workers. ${ }^{52}$ Moreover,

\footnotetext{
${ }^{50}$ The labor income share of a skilled group is defined as the compensation to employees belonging to the skill group divided by total income.

${ }^{51}$ To the extent that drivers have opposite effects on labor shares of different skill groups, the analysis of labor income share dynamics by skill can help better identify the drivers of the labor income share.

52،"Skill supply and other composition shifts" refers to the impact of relative skill supply measured by the share of low, middle, and high educational attainment in the total population and the contribution of the regression
} 
countries with higher exposure to routinization and greater increase in participation in global value chains have experienced stronger declines in the middle-skilled labor income share, which has been especially pronounced in Austria, Germany, and the United States. ${ }^{53}$ This finding is consistent with evidence for the United States and European economies, where declining costs of automating routine tasks have caused a polarization of employment and wages along the skill spectrum (Autor and Dorn 2013; Goos, Manning, and Salomons 2014). This finding also strongly suggests that the decline in the aggregate labor income share has been borne disproportionately by middle-skilled workers.

Because exposure to routine-biased technological progress differs across sectors, it is interesting to explore whether industries with higher exposures also experience stronger declines in their middle-skilled labor income shares. The skill-level analysis is therefore conducted at both the aggregate and the sectoral levels. In addition, the sector-level analysis can control for country-specific trends and is tested in a larger sample.

Results are consistent and robust across exercises, though coefficients are not strictly comparable due to a smaller (predominantly advanced economy) sample for the sectoral analysis, likely larger measurement errors of the price of investment goods and intermediate goods at the sectoral level, and greater mobility of factors across sectors than across countries. The cross-country analysis and the within-country cross-sectoral analysis may thus reflect somewhat different mechanisms. That said, findings from this analysis also suggest that measures of technological change have a stronger effect on the middle-skilled labor income share and that sectors more exposed to routine-biased technological progress experience a stronger decline in the labor income shares of middle-skilled workers (see Table 11), consistent with the aggregate-level skill results.

Finally, since changes in the skill-specific labor income share can be driven by employment or wage adjustment of the skill group, additional analysis in Table 12 presents regression estimates that control for changes in employment composition (measured as the share of each skill group in total hours). The impact of technological advancement on the middle-skilled labor income share is very similar, suggesting that the decline of the middleskilled labor share in response to advances in technology has occurred mostly through wage

constant, which measures other deterministic trends in each group's labor share. Since this is the averaged decomposition for all countries in the sample, there is no contribution from the residual.

${ }^{53}$ The stronger negative effect of global value chain participation over technology for the middle-skilled labor share is based on a sample that includes emerging market and developing economies, for whom the aggregate labor share results find that global value chain participations exerts a stronger downward pressure on labor shares than technology. Estimating and decomposing the fall in middle-skill labor share for a sample consisting only of advanced economies delivers the same ranking as for the aggregate labor share, that is, a much larger role of technology relative to global value chain participation (Figure 3.14). 
adjustment or relocation within broadly defined sectors. ${ }^{54}$ The robustness of these results is explored further by replacing country-specific trends by policy and institutional variables (Table 13).

\section{Summary and Policy Implications}

The analysis in this paper has highlighted the downward trend in the labor share of income at the global level since the early 1990s, as well as its heterogeneity across countries, sectors, and skill groups. In the vast majority of economies, within-sector declines, rather than labor reallocation toward low-labor-share sectors, have driven the overall decline in labor's share of income.

The empirical analysis points to a dominant role of technology and global integration in this trend, although to different degrees between advanced and emerging market economies. Technological progress, reflected in the steep decline in the relative price of investment goods, has been the key driver in advanced economies, along with high exposure to routine occupations that could be automated, with global integration also playing a role, albeit a smaller one.

The evidence also suggests that the impact of technological advancement and participation in global value chains on the aggregate labor share in advanced economies comes through a reduced share for middle-skilled labor. This finding corroborates existing evidence for advanced economies that automation and import competition and offshoring have led to long-term losses in middle-skill occupations and displacement of middle-skilled workers to lower-wage occupations.

In emerging markets as a group, the evolution of labor shares is explained predominantly by the forces of global integration, with a more limited role for technology. This difference, compared with advanced economy experiences, reflects, in part, a much less pronounced decline in the relative price of investment goods, as well as lower exposure to routinization, which has limited the ability of technology to displace labor. As noted above, this effect of global integration could be interpreted as benign - it results from capital deepening and has been associated with strong growth in wages and employment.

The design of specific policy responses will have to depend on country circumstances, given the sizable differences in levels of development, the extent of decline in labor shares and the relative importance of their underlying drivers, and existing social safety nets. In general, policies in advanced economies should be designed to help workers better cope with disruptions caused by technological progress and global integration, including through skill upgrading. More generally, long-term investment in education as well as

\footnotetext{
${ }^{54}$ The results also exhibit capital-skill complementarity: the coefficient on the relative price of investment suggests that low-skilled workers are more likely to be replaced by capital than middle- and high-skilled workers.
} 
opportunities for learning and skill upgrading throughout workers' careers, could help reduce the disruptions associated with technological change. Policies facilitating the reallocation of displaced workers to new jobs that, among other things, reduce the costs of job search and transitions, should also be a priority. These policies, however, might not be sufficient. To the extent that some workers are affected more permanently, longer-term redistributive measures might be required as well. These would need to be tailored to specific circumstances and anchored in each country's social contract.

In emerging markets and developing economies, global integration has allowed for expanded access to capital and technology and, by raising productivity and growth, led to a rise in living standards. In principle, the decline in the labor share of income may not by itself call for policy intervention but, as in advanced economies, policies should work to make access to opportunities as well as gains from growth broadly shared. Moreover, challenges similar to those in advanced economies could arise as automation progresses. Policies to promote skill deepening may therefore have an important role to play in preparing workers in emerging market and developing economies for further structural transformation in addition to facilitating the income convergence process. 


\section{Annex 1. Wages and Deflators}

Real wages can be calculated by deflating wages by consumer prices - the prices of goods and services bought by consumers - or by the GDP deflator - the prices of all goods and services produced in the economy.

The appropriate choice of deflator depends on the questions asked.

- The real or consumption wage - that is, the wage deflated using the consumer price index (CPI), is the value of workers' earnings in terms of the basket of goods and services they consume and thus more accurately reflects changes in purchasing power. This is relevant for assessing welfare implications for workers and, in turn, the political economy implications of changes in nominal wages.

- The product wage, deflated using the GDP deflator, is the measure affecting firms' hiring incentives and is more appropriate for comparisons with productivity when examining the functional distribution of GDP.

Figure 15. Decomposition of the Labor Share of Income, 1991-2014

(Percentage points per year)

- AES - EMDES
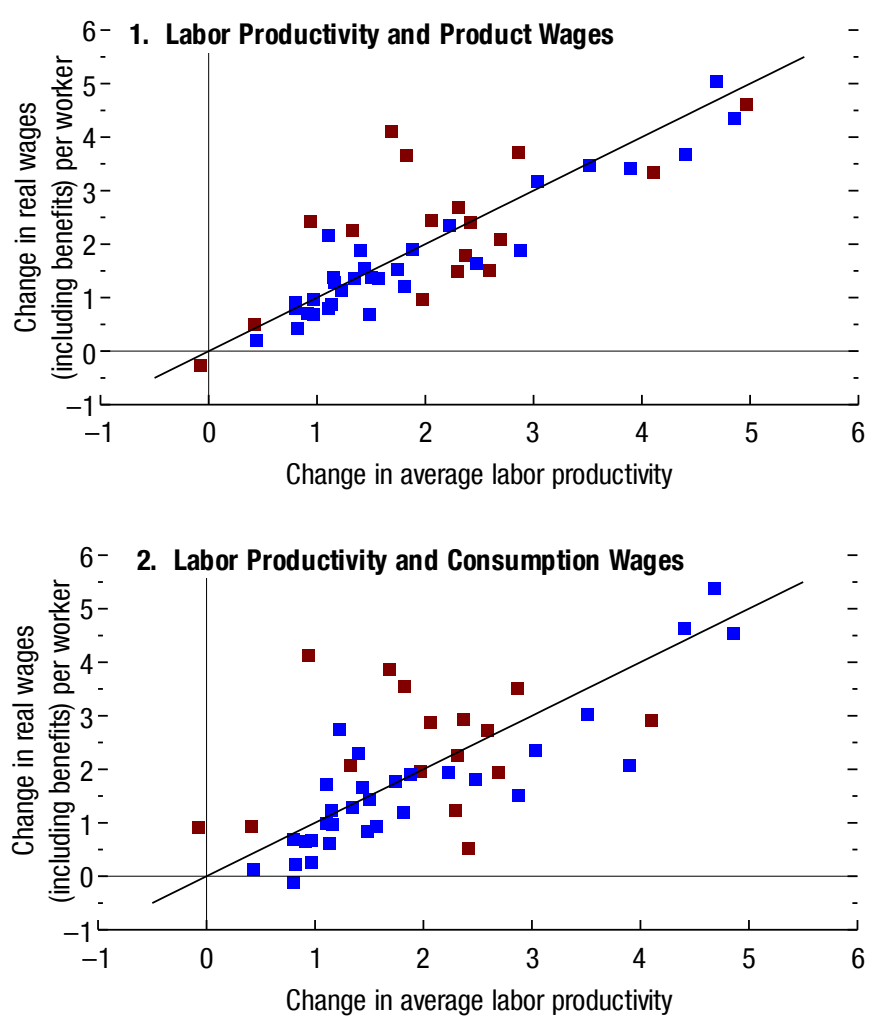

Source: IMF staff calculations. Note: Product wage is defined as norminal wage deflated by the GDP deflator, and consumption wage is defined as nominal wage deflated by the consumer price index. $\mathrm{AEs}=$ advanced economies; $\mathrm{EMDEs}=$ emerging market and developing economies.

The distinction between the two deflators is important for open economies, given that an increase in the price of an imported good, such as oil, increases the CPI relative to an output price index. Thus, real wages deflated using the CPI would appear to fall relative to productivity, even though this decline is driven only by differences in their respective deflators.

Such changes in the terms of trade would also have distributional implications depending on people's consumption of imports. Fajgelbaum and Khandelwal (2014), for example, note that 
poor consumers spend relatively more on imports, while high-income individuals consume relatively more services, a sector that is among the least traded.

Wage growth has been lagging productivity growth, which suggests that labor has been receiving an ever- smaller share of national income. Figure 15 shows changes in average labor productivity and changes in wages, deflated using the GDP deflator and using the CPI. Figure 16 shows the evolution of product wages, consumption wages, and average labor productivity in manufacturing for advanced economies. While the choice of deflator affects the exact evolution of wages over time, on average, consumption wages have increased less than product wages, and both have lagged productivity. ${ }^{55}$
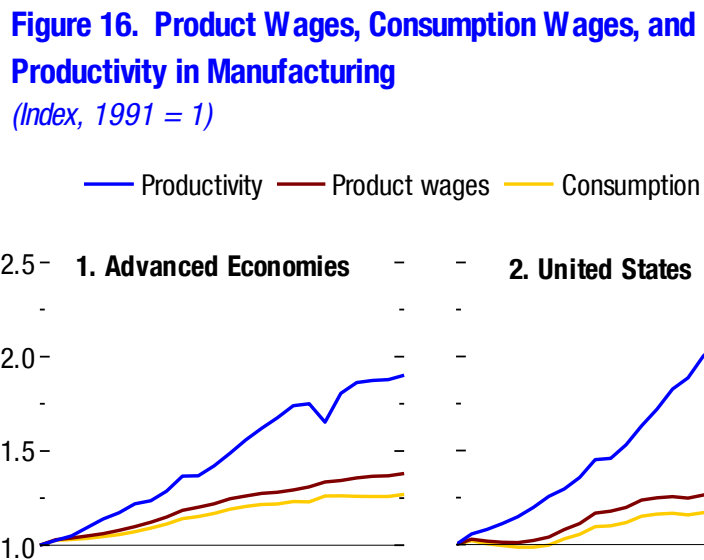

1.0
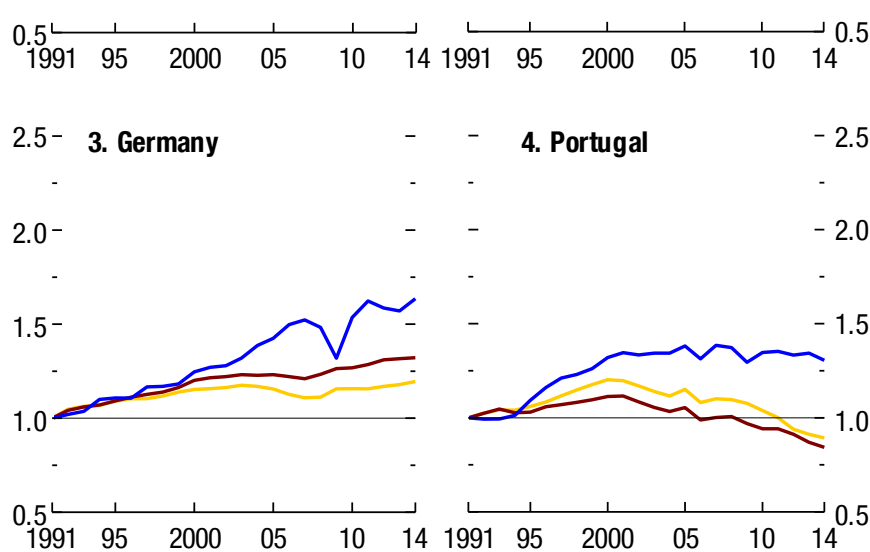

4. Portugal

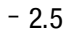

Source: IMF staff calculations

${ }^{55}$ This finding is in line with ILO 2015; Fleck, Glaser, and Sprague 2011; and Council of Economic Advisers 2014 for the United States. 


\section{Annex 2. A Theoretical Model of Relative Cost of Capital, Offshoring, and Labor Shares of Income in Advanced Economies and Emerging Market and Developing Economies $^{56}$}

This section develops a theoretical model to show how a fall in the relative cost of capital may influence offshoring and its impact on the labor share of income. This is motivated by the observation that a strong expansion of global value chains since the 1990s has coincided with a rapid fall in the relative cost of capital in advanced economies. ${ }^{57}$ Three important drivers of the cost of capital - the price of investment goods, the interest rate, and the corporate income tax - have declined substantially during this period, as shown in Figure 3.6. ${ }^{58}$ These drivers started trending down in the early 1980s and should have strongly influenced the labor cost share of individual tasks. Given that the offshoring of tasks from advanced economies to emerging market economies is driven mainly by wage differentials, it is natural to expect the incentive for offshoring to vary across tasks with different exposure to the fall in the cost of capital. This further influences labor income share dynamics by changing the composition of tasks with different levels of labor cost share.

The model highlights a mechanism by which participation in global value chains, when combined with a strong decline in the relative cost of capital, can simultaneously lead to lower labor shares in both advanced and emerging market economies. For advanced economies, the mechanism is straightforward: because offshored tasks are relatively labor intensive, the composition of remaining production becomes more capital intensive, and a decline in labor income shares ensues. For emerging market economies, the mechanism has two parts. First, the steep decline in the relative cost of capital leads firms in advanced economies to automate primarily tasks that can be performed easily by labor and to offshore those that cannot - that is, those with low elasticity of substitution between capital and labor - to emerging market economies. Second, because the relative cost of capital tends to be comparatively high in emerging market economies due to capital scarcity, tasks with low substitutability between factors will have higher capital shares than the average task, because firms cannot as easily exploit low relative labor costs to substitute labor for capital. Thus, offshoring will shift the composition of production toward tasks with higher capital shares, thereby lowering the aggregate labor income share in emerging market economies. ${ }^{59}$

\footnotetext{
${ }^{56}$ See Lian, forthcoming, for a more detailed analysis.

${ }^{57}$ Relative to wages.

${ }^{58}$ The depreciation rate of capital may rise during this period due to a larger share of software in capital (Eden and Gaggl 2015), which is however unlikely to offset other drivers' decline.

${ }^{59}$ The hypothesis that offshored tasks may be more capital intensive than existing tasks in emerging market and developing economies is proposed by Elsby, Hobijn, and Şahin (2013) and Cho (2016). Cho (2016) assumes that technology advancement has always been labor saving and that tasks that are relatively more labor intensive in advanced economies are offshored from them to emerging market economies. To the extent that these tasks use more advanced technology than is currently in use in emerging market economies or, equivalently, that these tasks have a lower labor income share than existing tasks in these economies, offshoring can reduce the labor income share. In contrast with Cho (2016), technology advancement causes a fall in the
} 
It is important to note that the model is not used to argue that offshoring is caused mainly by a decline in the cost of capital. Instead, the mechanism should hold with other important drivers of offshoring as well, such as its declining cost (Feenstra and Hanson 1997, and Grossman and Rossi-Hansberg 2008), because those drivers simply make all tasks more likely to be offshored and do not offset the mechanism emphasized here. Instead, the model is used to highlight that, in the presence of a fall in the relative cost of capital in an advanced economy, the types of tasks offshored tend to be such that they reduce the labor share in the receiving emerging market economy. ${ }^{60}$

To begin with, consider a spectrum of tasks that are produced by capital $K$ and labor $L$ through a constant elasticity of substitution production function:

$$
\left(\alpha K^{1-\frac{1}{\rho}}+(1-\alpha) L^{1-\frac{1}{\rho}}\right)^{\frac{\rho}{\rho-1}}
$$

in which $\alpha$ and $\rho$ govern the capital intensity and the elasticity of substitution between capital and labor. Both can differ across tasks. Cost minimization implies that the cost of producing one unit of output of task $\{\alpha, \rho\}$ is:

$$
c(r, w ; \alpha, \rho)=\left(\alpha^{\rho} r^{1-\rho}+(1-\alpha)^{\rho} w^{1-\rho}\right)^{\frac{1}{1-\rho}}
$$

in which $r$ denotes the cost of capital and $w$ denotes the wage.

The labor income share of the task $\{\alpha, \rho\}$ is:

$$
L S=\frac{1}{1+\alpha^{\rho}(1-\alpha)^{-\rho}\left(\frac{r}{w}\right)^{1-\rho}} .
$$

Therefore:

$$
\frac{\partial L S}{\partial\left(\frac{r}{w}\right)}=(\rho-1) \frac{\alpha^{\rho}(1-\alpha)^{-\rho}\left(\frac{r}{w}\right)^{-\rho}}{\left(1+\alpha^{\rho}(1-\alpha)^{-\rho}\left(\frac{r}{w}\right)^{1-\rho}\right)^{2}}
$$

Equation (3.2.1) suggests a critical role of the elasticity of substitution $\rho$ for the impact of the relative cost of capital on the labor income share. Specifically, a fall in the relative cost of capital $\frac{r}{w}$ leads to a decline in the labor income share if and only if the elasticity of substitution $\rho$ is larger than 1 .

To model offshoring from advanced economies to emerging market economies, the model looks at two countries with different wage levels and focuses on the offshoring of

cost of capital in this paper's model, which may or may not be labor saving, depending on whether the elasticity of substitution of tasks is above or below 1.

${ }^{60}$ Otherwise, offshoring could lead to a zero sum in terms of the impact on the global labor income share. 
tasks from the high-wage country to the low-wage country. The cost of producing a unit of task $\{\alpha, \rho\}$ in the high-wage country is $c(r, w ; \alpha, \rho)=\left(\alpha^{\rho} r^{1-\rho}+(1-\alpha)^{\rho} w^{1-\rho}\right)^{\frac{1}{1-\rho}}$, and due to assumed high failure rates and monitoring costs, the cost of producing one unit of task in the low-wage country is $(1+\tau) c\left(r, w^{\prime} ; \alpha, \rho\right)=(1+\tau)\left(\alpha^{\rho} r^{1-\rho}+(1-\alpha)^{\rho} w^{1-\rho}\right)^{\frac{1}{1-\rho}}$, in which $w^{\prime}<w$, and $\tau$ captures these costs of offshoring. The set of tasks A that are offshored from the high-wage to low-wage country can be defined as:

$$
A \triangleq\left\{(\alpha, \rho, \tau): c(r, w ; \alpha, \rho)>(1+\tau) c\left(r, w^{\prime} ; \alpha, \rho\right)\right\}
$$

The assumption that the cost of capital is the same for the high-wage and the lowwage countries is plausible, given that offshoring is often associated with foreign direct investment flows (Feenstra and Hanson 1997) that help achieve a relatively low cost of capital for the project considered, despite overall capital scarcity in emerging market economies. This also makes the model of offshoring presented here different from conventional trade theory, which assumes that capital does not move across countries. Capital mobility implies that offshoring will effectively contribute to capital deepening, reduce the cost of capital, and change the composition of tasks.

For simplicity, the analysis below is based on a partial equilibrium analysis in which $w$ and $w^{\prime}$ and the cost of capital are given exogenously. Lian (forthcoming) provides a general equilibrium analysis, which corroborates the main conclusions of this partial equilibrium analysis, given that the abundant labor supply in emerging market and developing economies implies that the wage increase in low-wage countries as a result of stronger demand for labor caused by offshoring would probably not be large enough to reverse the relationship $w>w^{\prime}$.

Equivalently, taking logs and rearranging terms, $A$ can be characterized as:

$$
A \triangleq\left\{(\alpha, \rho, \tau): \int_{w^{\prime}}^{w} \frac{\partial \ln c(r, z ; \alpha, \rho)}{\partial z} d z>\ln (1+\tau)\right\}
$$

The model studies labor income share dynamics caused by offshoring in two steps. First, the model proves that tasks with low elasticity of substitution are more likely - and those with high elasticity of substitution less likely - to be offshored if the relative cost of capital falls. Second, the model considers how the offshoring of tasks with low elasticity of substitution affects the labor income share in both the sending (advanced) economy and the receiving (emerging market) economies.

As a first step, Proposition 1 provides a comparative static result that a decline in the relative cost of capital makes the offshoring of tasks with elasticity of substitution higher than (lower than) 1 less (more) attractive.

Proposition 1: A decline in the cost of capital causes more tasks with $\rho<1$ and fewer tasks with $\rho>1$ to be offshored from the high-wage country to the low-wage country.

Proof: Through the use of algebra, it can be shown straightforwardly that: 


$$
\frac{\partial^{2} \ln c(r, w ; \alpha, \rho)}{\partial w \partial r}=(\rho-1) r^{\rho-2} w^{-\rho}\left(\frac{1-\alpha}{\alpha}\right)^{\rho} \frac{1}{\left[1+\left(\frac{1-\alpha}{\alpha}\right)^{\rho}\left(\frac{w}{r}\right)^{1-\rho}\right]^{2}}
$$

Therefore:

$$
\frac{\partial^{2} \ln c(r, w ; \alpha, \rho)}{\partial w \partial r}\left\{\begin{array}{ll}
>0 & \text { if } \rho>1 \\
<0 & \text { if } \rho<1
\end{array} .\right.
$$

Assume the cost of capital is $r_{1}$ initially and declines to $r_{2}<r_{1}$. Inequalities in (3.2.4) imply that:

$$
\begin{gathered}
\int_{w^{\prime}}^{w} \frac{\partial \ln c\left(r_{2}, z ; \alpha, \rho\right)}{\partial z} d z<\int_{w^{\prime}}^{w} \frac{\partial \ln c\left(r_{1}, z ; \alpha, \rho\right)}{\partial z} d z, \text { for any } \rho>1, \\
\int_{w^{\prime}}^{w} \frac{\partial \ln c\left(r_{2}, z ; \alpha, \rho\right)}{\partial z} d z>\int_{w^{\prime}}^{w} \frac{\partial \ln c\left(r_{1}, z ; \alpha, \rho\right)}{\partial z} d z, \text { for any } \rho<1 .
\end{gathered}
$$

The definition of the set of offshorable tasks as characterized by (3.2.3) implies that a decline in the cost of capital causes an expansion of the set of tasks that are offshored and have elasticity of substitution lower than 1, and a reduction of the set of tasks that are offshored and have elasticity of substitution higher than 1 .

As a second step, the model considers a decline in the cost of offshoring $\tau$ and studies how offshoring affects labor income shares in the low- and high-wage countries. In the current partial equilibrium analysis, the definition (3.2.3) implies directly that it causes more tasks to be offshored, regardless of their elasticity of substitution $\rho .{ }^{61}$ Because declines in the cost of capital and offshoring costs have conflicting effects on offshoring when $\rho>1$ while they reinforce each other when $\rho<1$, their combined effect should imply that tasks with $\rho<$ 1 are more likely to be offshored, as illustrated in Figure $17 .{ }^{62}$

\footnotetext{
${ }^{61}$ Lian (forthcoming) conducts simulations based on plausible parameters in a general equilibrium environment. These confirm that declining costs of offshoring substantially increase the number of tasks that are offshored from the high-wage to the low-wage country, despite a convergence in wage levels.

${ }^{62}$ This figure illustrates that the mechanism - the declining cost of capital makes tasks with elasticity of substitution lower than 1 more likely to be offshored than tasks with elasticity of substitution higher than 1 holds for other important drivers of offshoring. From panel 1 to panel 2, a decline in the cost of capital makes tasks with elasticity of substitution larger than 1 less likely to be offshored and those with elasticity of substitution less than 1 more likely to be offshored-as proved in Proposition 1. Next, from panel 2 to panel 3, a further decline in the cost of offshoring makes all tasks more likely to be offshored. With the two changes combined, it is evident that tasks with elasticity of substitution lower than 1 are more likely to be offshored than those with elasticity of substitution higher than 1 .
} 
Figure 17. Impact of the Costs of Capital and Offshoring on the Set of Tasks Offshored from a High-Wage Country to a LowWage Country
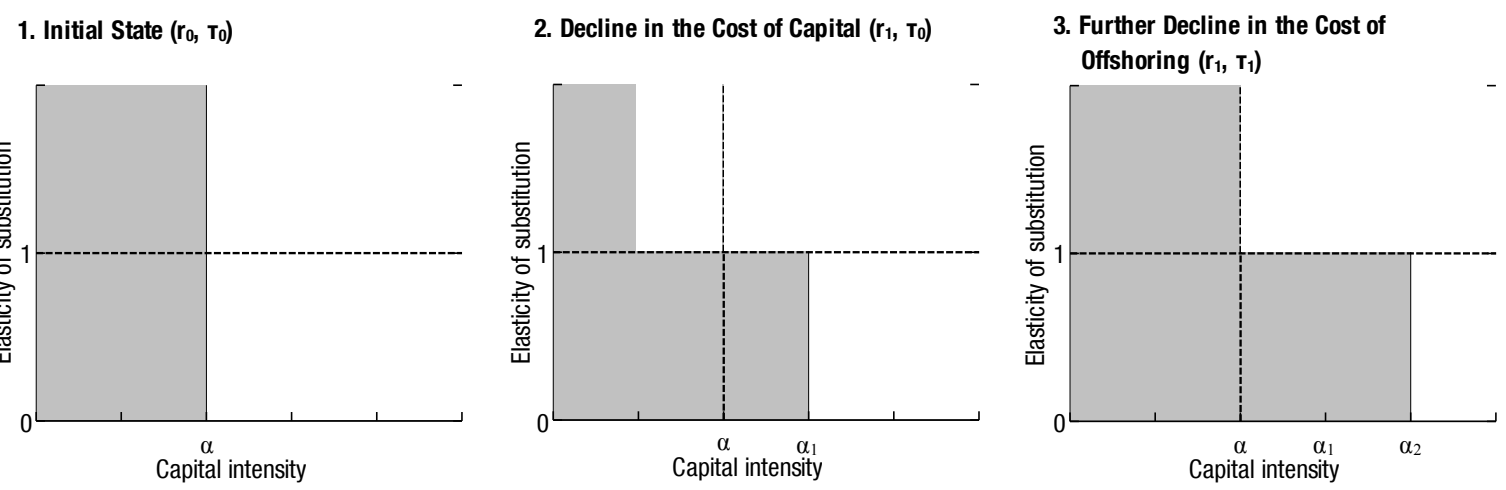

Source: IMF staff estimates.

Note: The shaded areas represent tasks that are offshored from the high-wage country to the low-wage country. This figure suggests that tasks with $\rho<1$ are more likely to be offshored than tasks with $\rho>1$ if there are declines in the cost of capital and the cost of offshoring, where $r_{0}$ and $r_{1}$ denote the cost of capital and $r_{0}>r_{1}$, and $\tau_{0}$ and $\tau_{1}$ denote the cost of offshoring and $\tau_{0}>r_{1}$. For illustrative purposes, all tasks with capital intensity below $\alpha$ are offshored in panel 1 , and the set of tasks with $\rho>1$ that are offshored in panel 3 are set to be identical with that in panel 1 .

For simplicity, to study how the offshoring of tasks with low elasticity of substitution affects the labor income share, it is helpful to consider a special case in which all offshorable tasks have a Leontief production function $F(K, L)=\min \left\{\frac{K}{a}, L\right\}$, implying zero elasticity of substitution between capital and labor, while non-offshorable tasks have a Cobb-Douglas production function, implying an elasticity of substitution equal to 1 . It is further assumed that consumers have a log preference function over the tasks.

Proposition 2: If the average labor income share of offshorable tasks is the same as that of non-offshorable tasks, offshoring because of a decline in the costs of capital and offshoring can reduce the labor income share in the high-wage country.

Proof: for task $a$, the labor income share is

$$
\frac{w L}{F(K, L)}=\frac{w L}{w L+r(a L)}=\frac{1}{1+a \frac{r}{w}} .
$$

Using definition (3.2.3), it is straightforward to show that any task $a$ that is offshored from high- to low-wage countries satisfy $a<a^{*}$, in which $a^{*}=\frac{w-(1+\tau) w^{\prime}}{\tau r}$. As the labor income share is declining in $a$, the remaining tasks become more capital intensive, which reduces the labor income share in the high-wage country.

The log preference function of consumers ensures that the share of each task in aggregate expenditure is constant, so a decline in labor income share within offshored tasks implies that offshoring will drive down the global labor income share. ${ }^{63}$

\footnotetext{
${ }^{63}$ For details, see Lian (forthcoming).
} 
Finally, it is generally possible for offshoring to reduce the labor income share in the low-wage country as well. As mentioned above, offshored tasks are likely to be predominantly those with low elasticity of substitution. As a result, the share of tasks with low elasticity of substitution will increase in the low-wage country. To the extent that the average labor income share of tasks with elasticity of substitution lower than 1 is substantially lower than that of those with elasticity of substitution equal to or greater than 1 , offshoring may reduce the aggregate labor income share in the low-wage country. ${ }^{64}$

\section{Annex 3. Country Coverage and Data}

The analysis is based on countries with at least 10 years of data on labor shares over the 1991-2014 period, resulting in a sample of 31 advanced economies and 18 emerging market economies for the aggregate analysis and a sample of 27 advanced economies for the sectoral analysis. For the skill-based results, a sample of 27 advanced economies and 10 emerging market economies is included at the aggregate level, and 27 advanced economies and 5 emerging market economies are included at the sectoral level (see Table 1).

The paper assembles a new data set on labor shares based on primary sources from national authorities for most major economies, as well as on data from the Organisation for Economic Cooperation and Development and the data set of Karabarbounis and Neiman (2014). The primary data sources for other variables used in this paper are the IMF's World Economic Outlook, Organisation for Economic Co-operation and Development, CEIC, Penn World Tables 9.0 database, World Bank, World Development Indicators database, World Input-Output database, Eora Multi-Regional Input-Output database, United Nations Industrial Development Organization database, and United Nations Comtrade database.

The routine task intensity measure relies on Autor and Dorn's (2013) data for routine, manual, and abstract task inputs; the offshorability measure is constructed using data from Blinder and Krueger (2013). For the calculation of aggregate and sectoral routinization and offshorability scores, the paper incorporates employment by industry and occupation data from the International Labour Organization, Integrated Public Use Microdata Series (IPUMS) International, IPUMS USA, and the National Bureau of Statistics of China. A summary of variable description and sources is given in Table 2.

\footnotetext{
${ }^{64}$ This is likely if also taking into account capital scarcity— possible strong credit rationing in emerging market and developing economies, which may limit the access to capital for many private sector firms.
} 


\section{Annex 4. Tables}

Table 1. Country Coverage

\begin{tabular}{|c|c|}
\hline Aggregate Long-Term Analysis & $\begin{array}{l}\text { Australia, Austria, Belgium, Canada, Cyprus, Czech Republic, Denmark, } \\
\text { Estonia, Finland, France, Germany, Greece, Iceland, Ireland, Italy, Japan, } \\
\text { Korea, Latvia, Lithuania, Malta, Netherlands, New Zealand, Norway, } \\
\text { Portugal, Singapore, Slovak Republic, Slovenia, Spain, Sweden, United } \\
\text { Kingdom, United States } \\
\text { Brazil, Bulgaria, Chile, China, Costa Rica, Egypt, Hungary, Indonesia, } \\
\text { Kyrgyz Republic, Mexico, Morocco, Peru, Philippines, Poland, Romania, } \\
\text { South Africa, Thailand, Turkey }\end{array}$ \\
\hline Aggregate Stacked Five-Year Analysis & $\begin{array}{l}\text { Australia, Austria, Belgium, Canada, Cyprus, Czech Republic, Denmark, } \\
\text { Estonia, Finland, France, Germany, Greece, Iceland, Ireland, Italy, Japan, } \\
\text { Korea, Latvia, Lithuania, Malta, Netherlands, New Zealand, Norway, } \\
\text { Portugal, Singapore, Slovak Republic, Slovenia, Spain, Sweden, United } \\
\text { Kingdom, United States } \\
\text { Bolivia, Brazil, Bulgaria, Chile, China, Croatia, Egypt, Hungary, } \\
\text { Indonesia, Jamaica, Kyrgyz Republic, Mexico, Morocco, Namibia, Peru, } \\
\text { Philippines, Poland, Romania, South Africa, Tanzania, Thailand, Turkey, } \\
\text { Venezuela }\end{array}$ \\
\hline Sectoral Analysis & $\begin{array}{l}\text { Australia, Austria, Belgium, Canada, Czech Republic, Denmark, Estonia, } \\
\text { Finland, France, Germany, Greece, Iceland, Ireland, Italy, Japan, Korea, } \\
\text { Netherlands, New Zealand, Norway, Portugal, Singapore, Slovak } \\
\text { Republic, Slovenia, Spain, Sweden, United Kingdom, United States }\end{array}$ \\
\hline Aggregate Analysis by Skill & $\begin{array}{l}\text { Australia, Austria, Belgium, Canada, Cyprus, Czech Republic, Denmark, } \\
\text { Estonia, Finland, France, Germany, Greece, Ireland, Italy, Japan, Korea, } \\
\text { Latvia, Lithuania, Malta, Netherlands, Portugal, Slovak Republic, } \\
\text { Slovenia, Spain, Sweden, United Kingdom, United States } \\
\text { Brazil, Bulgaria, China, Hungary, India, Indonesia, Mexico, Poland, } \\
\text { Romania, Turkey }\end{array}$ \\
\hline Sectoral Analysis by Skill & $\begin{array}{l}\text { Australia, Austria, Belgium, Canada, Czech Republic, Denmark, Estonia, } \\
\text { Finland, France, Germany, Greece, Iceland, Ireland, Italy, Japan, Korea, } \\
\text { Netherlands, New Zealand, Norway, Portugal, Singapore, Slovak } \\
\text { Republic, Slovenia, Spain, Sweden, United Kingdom, United States } \\
\text { Brazil, China, Mexico, Romania, Turkey }\end{array}$ \\
\hline
\end{tabular}

Source: IMF staff compilation. 
Table 2. Data Sources

Indicator

Labor Share (Aggregate)

Labor Share (Sectoral)

Labor Share by Skill

Price of Investment

Intermediate Imports

Global Value Chain Participation

Domestic Value Added

Imports and Exports of Goods and Services

Union Density Rate

Routinization

Corporate Income Tax

GDP, Per Capita GDP

External Assets and Liabilities

Credit to Private Sector

Inflation Expectations

Capital Depreciation Rate

Old-Age Dependency Ratio

Migrant Stock

Relative Skill Supply (Percent of population with

primary, secondary, tertiary education)

Long-Term Treasury Yield
Source

Karabarbounis and Neiman (2014); national authorities; Organisation for Economic Co-operation and Development

CEIC database; EU KLEMS database; Organisation for Economic Cooperation and Development

World Input-Output Database, Socio Economic Accounts, Release of July 2014

IMF, World Economic Outlook database

EORA MRIO database; World Input-Output Database

EORA MRIO database; IMF staff calculations

EORA MRIO database

IMF, World Economic Outlook database

Database on Institutional Characteristics of Trade Unions, Wage Setting, State Intervention and Social Pacts; Organisation for Economic Cooperation and Development

Autor and Dorn (2014); European Union Labor Force Survey; Eurostat; IPUMS International; IPUMS USA; International Labour Organization; national authorities; United Nations

IMF, Fiscal Monitor database

IMF, World Economic Outlook database

External Wealth of Nations Mark II database

World Bank World Development Indicators database

Consensus Forecast database; IMF, World Economic Outlook database

World Bank database

World Bank database

United Nations database

Barro Lee Educational Attainment for Population Aged 15 and over database (2013); World Input-Output Database; IMF staff calculations IMF, International Financial Statistics database; IMF, World Economic Outlook database

Source: IMF staff compilation.

Note: IPUMS = Integrated Public Use Microdata Series; MRI0 = Multi-Region Input-Output. 
Table 3. Baseline Aggregate Results

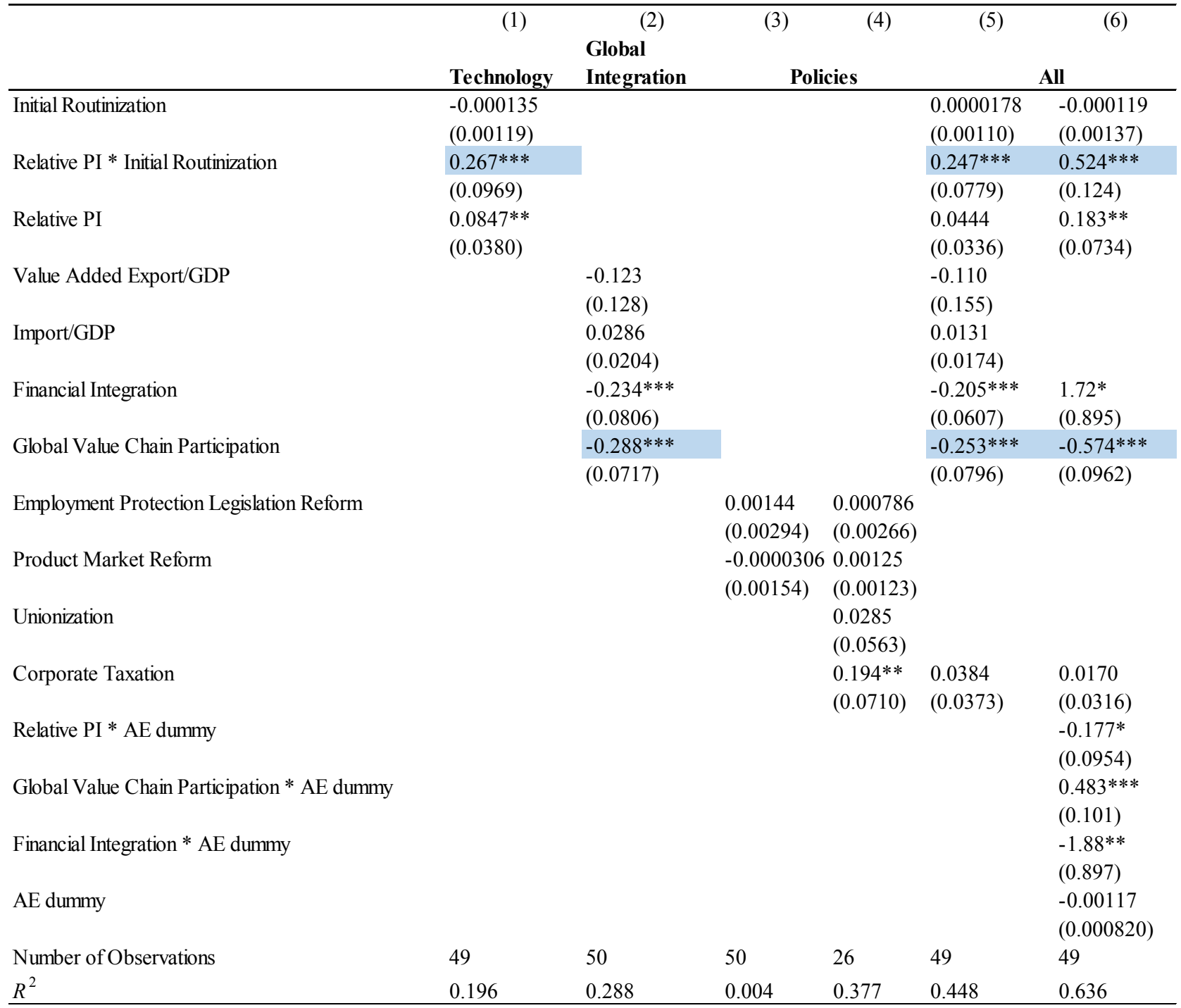

Source: IMF staff calculations.

Note: All variables (except initial routinization) are expressed as long-term changes. Robust standard errors are in parentheses. Here and in all subsequent tables, the long-term change in financial integration, measured as the sum of external assets and liabilities in percent of domestic GDP, is divided by 100 . AEs = advanced economies; PI = price of investment.

$* * * p<0.01, * * p<0.05, * p<0.1$ 
Table 4. Stacked Aggregate Results

\begin{tabular}{|c|c|c|c|c|c|c|}
\hline & (1) & (2) & (3) & (4) & (5) & $(6)$ \\
\hline & \multicolumn{5}{|c|}{ Ordinary Least Square Estimations } & Robust Regression \\
\hline \multicolumn{7}{|l|}{ Technology } \\
\hline Initial Routinization & $\begin{array}{l}-0.00222^{*} \\
(0.00120)\end{array}$ & $\begin{array}{l}-0.0150^{*} \\
(0.00887)\end{array}$ & & $\begin{array}{c}-0.0126 \\
(0.00819)\end{array}$ & $\begin{array}{l}-0.0149 * * \\
(0.00644)\end{array}$ & $\begin{array}{c}-0.0293 * * * \\
(0.00459)\end{array}$ \\
\hline Relative PI & $\begin{array}{c}0.0339 \\
(0.0279)\end{array}$ & $\begin{array}{c}0.0535 \\
(0.0434)\end{array}$ & & $\begin{array}{c}0.0112 \\
(0.0457)\end{array}$ & $\begin{array}{c}0.0615 \\
(0.0489)\end{array}$ & $\begin{array}{c}0.0223 \\
(0.0350)\end{array}$ \\
\hline Relative PI * Initial Routinization & $\begin{array}{l}0.128 * * \\
(0.0530)\end{array}$ & $\begin{array}{c}0.101 \\
(0.201)\end{array}$ & & $\begin{array}{c}0.233 \\
(0.193)\end{array}$ & $\begin{array}{c}0.207 \\
(0.172)\end{array}$ & $\begin{array}{c}0.273 * * \\
(0.116)\end{array}$ \\
\hline \multicolumn{7}{|l|}{ Global Integration } \\
\hline Global Value Chain Participation & $\begin{array}{l}-0.152^{* *} \\
(0.0655)\end{array}$ & $\begin{array}{c}-0.207 * * * \\
(0.0627)\end{array}$ & & $\begin{array}{c}-0.253^{* * *} \\
(0.0632)\end{array}$ & $\begin{array}{c}-0.174^{*} \\
(0.0911)\end{array}$ & $\begin{array}{l}-0.131^{* *} \\
(0.0628)\end{array}$ \\
\hline Financial Integration & $\begin{array}{c}0.0890 * * * \\
(0.0219)\end{array}$ & $\begin{array}{c}0.0726^{*} \\
(0.0369)\end{array}$ & & $\begin{array}{c}0.0744 * * \\
(0.0338)\end{array}$ & $\begin{array}{l}0.0312 \\
(0.046)\end{array}$ & $\begin{array}{c}0.0784 \\
(0.0568)\end{array}$ \\
\hline \multicolumn{7}{|l|}{ Policy } \\
\hline Corporate Taxation & $\begin{array}{c}0.0201 \\
(0.0524)\end{array}$ & $\begin{array}{c}0.0709 \\
(0.0711)\end{array}$ & & $\begin{array}{c}0.0651 \\
(0.0646)\end{array}$ & $\begin{array}{c}0.0511 \\
(0.0573)\end{array}$ & $\begin{array}{c}0.127^{* * *} \\
(0.0425)\end{array}$ \\
\hline Employment Protection Legislation Reform & & & $\begin{array}{l}-0.00207^{* *} \\
(0.000806)\end{array}$ & $\begin{array}{l}-0.0000182 \\
(0.000854)\end{array}$ & $\begin{array}{l}0.000291 \\
(0.00104)\end{array}$ & $\begin{array}{c}-0.000626 \\
(0.000794)\end{array}$ \\
\hline Product Market Reform & & & $\begin{array}{l}-0.000780 \\
(0.000771)\end{array}$ & & & \\
\hline Country Fixed Effects & $\mathrm{N}$ & $\mathrm{Y}$ & $\mathrm{Y}$ & $\mathrm{Y}$ & $\mathrm{Y}$ & Y \\
\hline Period Fixed Effects & $\mathrm{N}$ & $\mathrm{N}$ & $\mathrm{N}$ & $\mathrm{N}$ & $\mathrm{Y}$ & $\mathrm{Y}$ \\
\hline Number of Observations & 165 & 165 & 181 & 154 & 154 & 153 \\
\hline$R^{2}$ & 0.157 & 0.197 & 0.038 & 0.238 & 0.501 & 0.834 \\
\hline
\end{tabular}

Source: IMF staff calculations.

Note: All variables (except initial routinization) are expressed as long-term changes. Robust standard errors are clustered at the country level. PI = price of investment.

*** $p<0.01,{ }^{* *} p<0.05, * p<0.1$ 
Table 5. Aggregate Results, Robustness (User Cost)

(1)

(2)

(3)

(4)

Baseline User Cost of Capital Credit/GDP

\begin{tabular}{lllll}
\hline Initial Routinization & -0.00103 & 0.00228 & 0.00214 & -0.000356 \\
& $(0.000809)$ & $(0.00280)$ & $(0.00188)$ & $(0.00075)$ \\
Relative PI * Initial Routinization & $0.285^{* * *}$ & & & $0.220^{* * *}$ \\
& $(0.0743)$ & & & $(0.0702)$ \\
Relative PI & $0.0556^{*}$ & & & 0.0450 \\
& $(0.0327)$ & & & $(0.0296)$ \\
Global Value Chain Participation & $-0.166^{* *}$ & & $-0.168^{* *}$ & $-0.235^{* * *}$ \\
& $(0.0653)$ & & $(0.0751)$ & $(0.0651)$ \\
Trade Integration & 0.00794 & & 0.0137 & 0.0126 \\
& $(0.0183)$ & & $(0.0206)$ & $(0.0200)$ \\
Financial Integration & $-0.182^{*}$ & & $-0.220^{*}$ & $-0.236^{* *}$ \\
& $(0.0973)$ & & $(0.120)$ & $(0.106)$ \\
Corporate Taxation & 0.0440 & & 0.0676 & 0.0299 \\
Initial Routinization * User Cost of Capital & $(0.0496)$ & & $(0.0549)$ & $(0.0403)$ \\
& & $0.121^{* *}$ & $0.0889 *$ & \\
User Cost of Capital & & $(0.0613)$ & $(0.0541)$ & \\
Private Credit/GDP & & 0.00320 & 0.00290 & \\
Number of Observations & & $(0.0161)$ & $(0.0137)$ & \\
$R^{2}$ & & & & $0.0290^{*}$ \\
\hline
\end{tabular}

Source: IMF staff calculations.

Note: All variables (except initial routinization) are expressed as long-term changes. Robust standard errors are in parentheses. PI $=$ price of investment.

$* * * p<0.01, * * p<0.05, * p<0.1$ 
Table 6. Aggregate Results, Robustness (Alternative Measure of Offshoring)

\begin{tabular}{|c|c|c|c|c|}
\hline & $\begin{array}{c}\text { Imported } \\
\text { Interme diate } \\
\text { Inputs/GDP }\end{array}$ & $\begin{array}{c}(2) \\
\text { Imported } \\
\text { Intermdiate } \\
\text { Inputs/Total } \\
\text { Interme diate } \\
\text { Use } \\
\end{array}$ & $\begin{array}{c}(3) \\
\text { Imported } \\
\text { Inte rme diate/ } \\
\text { GDP } \\
\text { excluding } \\
\text { Commodities }\end{array}$ & $\begin{array}{c}\text { De-jure } \\
\text { Meas ure } \\
\text { of Offs horing }\end{array}$ \\
\hline Intermediate Goods Trade & $\begin{array}{l}-0.499 * * * \\
(0.161)\end{array}$ & $\begin{array}{l}-0.397 * * * \\
(0.0979)\end{array}$ & $\begin{array}{l}-0.242 * \\
(0.135)\end{array}$ & \\
\hline Initial Offshorability & & & & $\begin{array}{l}0.000154 \\
(0.00223)\end{array}$ \\
\hline Initial Offshorability*Import Price Index & & & & $\begin{array}{l}0.159 * * \\
(0.0670)\end{array}$ \\
\hline Import Price Index & & & & $\begin{array}{l}0.00343 \\
(0.0128)\end{array}$ \\
\hline Import/GDP & $\begin{array}{l}0.0161 \\
(0.0166)\end{array}$ & $\begin{array}{l}-0.0000922 \\
(0.0155)\end{array}$ & $\begin{array}{l}-0.00146 \\
(0.0134)\end{array}$ & $\begin{array}{l}-0.0481^{*} \\
(0.0276)\end{array}$ \\
\hline Value-Added Export/GDP & $\begin{array}{l}0.0800 \\
(0.180)\end{array}$ & $\begin{array}{l}0.229 \\
(0.167)\end{array}$ & $\begin{array}{l}0.0395 \\
(0.160)\end{array}$ & $\begin{array}{l}-0.0526 \\
(0.193)\end{array}$ \\
\hline Financial Integration & $\begin{array}{l}-0.160 * * \\
(0.0604)\end{array}$ & $\begin{array}{l}-0.169 * * * \\
(0.0593)\end{array}$ & $\begin{array}{l}-0.0764 \\
(0.0720)\end{array}$ & $\begin{array}{l}-0.152 * * \\
(0.0726)\end{array}$ \\
\hline Initial Routinization & $\begin{array}{l}-0.0000345 \\
(0.00118)\end{array}$ & $\begin{array}{l}-0.000421 \\
(0.00103)\end{array}$ & $\begin{array}{l}-0.0213 \\
(0.00117)\end{array}$ & $\begin{array}{l}-0.154 \\
(0.00167)\end{array}$ \\
\hline Relative PI * Initial Routinization & $\begin{array}{l}0.261 * * * \\
(0.0879)\end{array}$ & $\begin{array}{l}0.339 * * * \\
(0.0829)\end{array}$ & $\begin{array}{l}0.211 * * \\
(0.0959)\end{array}$ & $\begin{array}{l}0.230 * * \\
(0.0943)\end{array}$ \\
\hline Relative PI & $\begin{array}{l}0.0539 \\
(0.0335)\end{array}$ & $\begin{array}{l}0.0740 * * \\
(0.0303)\end{array}$ & $\begin{array}{l}0.0431 \\
(0.0357)\end{array}$ & $\begin{array}{l}0.0697 * \\
(0.0366)\end{array}$ \\
\hline Corporate Taxation & $\begin{array}{l}0.0536 \\
(0.0410)\end{array}$ & $\begin{array}{l}0.0510 \\
(0.0406)\end{array}$ & $\begin{array}{l}0.0946^{* *} \\
(0.0414)\end{array}$ & $\begin{array}{l}0.107 * * * \\
(0.0381)\end{array}$ \\
\hline Number of Observations & 49 & 49 & 48 & 48 \\
\hline$R^{2}$ & 0.417 & 0.470 & 0.335 & 0.400 \\
\hline
\end{tabular}

Source: IMF staff calculations.

Note: All variables (except initial routinization) are expressed as long-term changes. Robust standard errors are in parentheses. $\mathrm{PI}=$ price of investment.

$* * * p<0.01, * * p<0.05, * p<0.1$ 
Table 7. Aggregate Results, Robustness (Other Robustness Checks)

\begin{tabular}{|c|c|c|c|c|c|}
\hline & $\begin{array}{c}\text { Robust } \\
\text { Regression } \\
\end{array}$ & $\begin{array}{c}\text { GDP } \\
\text { Weighted } \\
\end{array}$ & $\begin{array}{c}(3) \\
\text { AE, No } \\
\text { Transition } \\
\text { Countries } \\
\end{array}$ & $\begin{array}{c}\text { Additional } \\
\text { Controls }\end{array}$ & $\begin{array}{c}(5) \\
\text { Without } \\
\text { Global } \\
\text { Financial } \\
\text { Crisis }\end{array}$ \\
\hline Initial Routinization & $\begin{array}{l}-0.000332 \\
(0.00093)\end{array}$ & $\begin{array}{l}0.00120 \\
(0.00102)\end{array}$ & $\begin{array}{l}0.00160 \\
(0.00363)\end{array}$ & $\begin{array}{l}-0.00171 \\
(0.00125)\end{array}$ & $\begin{array}{l}-0.00128 \\
(0.00155)\end{array}$ \\
\hline Relative PI * Initial Routinization & $\begin{array}{l}0.235^{* * *} \\
(0.0835)\end{array}$ & $\begin{array}{l}0.335^{* *} \\
(0.132)\end{array}$ & $\begin{array}{l}0.923 * * \\
(0.430)\end{array}$ & $\begin{array}{l}0.282 * * * \\
(0.0846)\end{array}$ & $\begin{array}{l}0.292^{* *} \\
(0.111)\end{array}$ \\
\hline Relative PI & $\begin{array}{l}0.0317 \\
(0.0364)\end{array}$ & $\begin{array}{l}0.150^{* *} \\
(0.0675)\end{array}$ & $\begin{array}{l}-0.0646 \\
(0.0832)\end{array}$ & $\begin{array}{l}0.0360 \\
(0.0316)\end{array}$ & $\begin{array}{l}0.0586 \\
(0.0432)\end{array}$ \\
\hline Global Value Chain Participation & $\begin{array}{l}-0.235^{* * *} \\
(0.0809)\end{array}$ & $\begin{array}{l}-0.282^{* *} \\
(0.120)\end{array}$ & $\begin{array}{l}-0.0838^{* *} \\
(0.0342)\end{array}$ & $\begin{array}{l}-0.384 * * * \\
(0.0664)\end{array}$ & $\begin{array}{l}-0.145^{* *} \\
(0.0600)\end{array}$ \\
\hline Financial Integration & $\begin{array}{l}-0.206 \\
(0.131)\end{array}$ & $\begin{array}{l}-0.105 \\
(0.0901)\end{array}$ & $\begin{array}{l}-0.184^{* *} \\
(0.0813)\end{array}$ & $\begin{array}{l}-0.206^{* * *} \\
(0.0657)\end{array}$ & $\begin{array}{l}-0.164^{* *} \\
(0.0714)\end{array}$ \\
\hline Corporate Taxation & $\begin{array}{l}0.0406 \\
(0.0497)\end{array}$ & $\begin{array}{l}-0.000645 \\
(0.0395)\end{array}$ & $\begin{array}{l}0.0658 \\
(0.0469)\end{array}$ & $\begin{array}{l}0.00808 \\
(0.0485)\end{array}$ & $\begin{array}{l}0.120 \\
(0.0749)\end{array}$ \\
\hline Old-Age Dependency Ratio & & & & $\begin{array}{l}0.000312 \\
(0.000995)\end{array}$ & \\
\hline Migrant Stock & & & & $\begin{array}{l}0.0629 \\
(0.139)\end{array}$ & \\
\hline Initial GDP per Capita & & & & $\begin{array}{l}0.000399 \\
(0.000595)\end{array}$ & \\
\hline Human Capital & & & & $\begin{array}{l}0.541 \\
(0.335)\end{array}$ & \\
\hline Number of Observations & 49 & 49 & 25 & 44 & 50 \\
\hline$R^{2}$ & 0.357 & 0.425 & 0.584 & 0.581 & 0.338 \\
\hline
\end{tabular}

Source: IMF staff calculations.

Note: All variables (except initial routinization and initial GDP per capita) are expressed as long-term changes. Robust standard errors are in parentheses. $\mathrm{AE}=$ advanced economies. $\mathrm{PI}=$ price of investment.

*** $p<0.01, * * p<0.05, * p<0.1$ 
Table 8. Aggregate Results, Robustness (Measurement Issues)

\begin{tabular}{|c|c|c|c|c|}
\hline & $\begin{array}{c}\text { Baseline } \\
\text { Labor } \\
\text { Share }\end{array}$ & $\begin{array}{c}\text { Self- } \\
\text { Employment- } \\
\text { Adjus ted } \\
\text { Labor Share }\end{array}$ & $\begin{array}{c}\text { Depreciation- } \\
\text { Adjusted } \\
\text { Labor Share }\end{array}$ & $\begin{array}{c}\text { Self- } \\
\text { Employment- } \\
\text { and } \\
\text { Depreciation- } \\
\text { Adjusted Labor } \\
\text { Share }\end{array}$ \\
\hline Initial Routinization & $\begin{array}{l}0.0000178 \\
(0.00110)\end{array}$ & $\begin{array}{l}0.00691 * * \\
(0.00300)\end{array}$ & $\begin{array}{l}0.000655 \\
(0.00173)\end{array}$ & $\begin{array}{l}0.00762^{* *} \\
(0.00346)\end{array}$ \\
\hline Relative PI * Initial Routinization & $\begin{array}{l}0.247 * * * \\
(0.0779)\end{array}$ & $\begin{array}{l}0.460 * \\
(0.264)\end{array}$ & $\begin{array}{l}0.322 * * * \\
(0.0933)\end{array}$ & $\begin{array}{l}0.570^{*} \\
(0.305)\end{array}$ \\
\hline Relative PI & $\begin{array}{l}0.0444 \\
(0.0336)\end{array}$ & $\begin{array}{l}-0.0484 \\
(0.120)\end{array}$ & $\begin{array}{l}0.0616 \\
(0.0493)\end{array}$ & $\begin{array}{l}-0.0901 \\
(0.138)\end{array}$ \\
\hline Global Value Chain Participation & $\begin{array}{l}-0.253^{* * *} \\
(0.0796)\end{array}$ & $\begin{array}{l}-0.617^{* *} \\
(0.252)\end{array}$ & $\begin{array}{l}-0.227^{*} \\
(0.134)\end{array}$ & $\begin{array}{l}-0.665^{* *} \\
(0.291)\end{array}$ \\
\hline Value Added Export/GDP & $\begin{array}{l}-0.110 \\
(0.155)\end{array}$ & $\begin{array}{l}-0.0223 \\
(0.482)\end{array}$ & $\begin{array}{l}-0.0205 \\
(0.197)\end{array}$ & $\begin{array}{l}0.0937 \\
(0.557)\end{array}$ \\
\hline Import/GDP & $\begin{array}{l}0.0131 \\
(0.0174)\end{array}$ & $\begin{array}{l}0.0655 \\
(0.0864)\end{array}$ & $\begin{array}{l}-0.0304 \\
(0.0288)\end{array}$ & $\begin{array}{l}0.0222 \\
(0.0998)\end{array}$ \\
\hline Financial Integration & $\begin{array}{l}-0.205^{* * *} \\
(0.0607)\end{array}$ & $\begin{array}{l}-0.346 \\
(0.402)\end{array}$ & $\begin{array}{l}-0.0903 \\
(0.0945)\end{array}$ & $\begin{array}{l}-0.255 \\
(0.464)\end{array}$ \\
\hline Corporate Taxation & $\begin{array}{l}0.0384 \\
(0.0373)\end{array}$ & $\begin{array}{l}0.119 \\
(0.155)\end{array}$ & $\begin{array}{l}0.0798 \\
(0.0615)\end{array}$ & $\begin{array}{l}0.170 \\
(0.178)\end{array}$ \\
\hline Number of Observations & 49 & 48 & 49 & 48 \\
\hline$R^{2}$ & 0.448 & 0.362 & 0.339 & 0.377 \\
\hline
\end{tabular}

Source: IMF staff calculations.

Note: All variables (except initial routinization) are expressed as long-term changes. Robust standard errors are in parentheses. PI $=$ price of investment.

${ }^{* * *} p<0.01,{ }^{* *} p<0.05,{ }^{*} p<0.1$ 
Table 9. Baseline Sectoral Results

\begin{tabular}{lcc}
\hline & $\begin{array}{c}\text { Tradables } \\
\text { Sectors }\end{array}$ & $\begin{array}{c}\text { Nontradables } \\
\text { Sectors }\end{array}$ \\
\hline Relative PI & 0.000412 & $-0.00167^{* * *}$ \\
Initial Routinization & $(0.000279)$ & $(0.000491)$ \\
& $-0.00598^{* *}$ & -0.00584 \\
Relative PI * Initial Routinization & $(0.00256)$ & $(0.00879)$ \\
& -0.0000989 & $0.00486^{* *}$ \\
Trade Integration & $(0.000488)$ & $(0.00181)$ \\
& $-0.000673^{* *}$ & -0.0000691 \\
Financial Integration & $(0.000292)$ & $(0.000122)$ \\
& 0.00356 & 0.0267 \\
Global Value Chain Participation & $(0.0100)$ & $(0.0180)$ \\
& $-0.00220^{* *}$ & 0.00171 \\
Country Fixed Effects & $(0.000857)$ & $(0.00279)$ \\
Sector Fixed Effects & $\mathrm{Y}$ & $\mathrm{Y}$ \\
Number of Observations & $\mathrm{Y}$ & $\mathrm{Y}$ \\
$R^{2}$ & 92 & 37 \\
\hline
\end{tabular}

Source: IMF staff calculations.

Note: For country coverage and a description of included variables, see Annex 3.3; for a detailed description of the estimation strategy, see Annex 3.4. Tradables sectors include agriculture, mining and quarry ing, manufacturing, wholesale and retail trade, and transportation. Nontradables sectors include construction, finance, real estate, government, and community. All variables (except for initial routinization) are expressed as long-term trend changes. Trade integration refers to value added exports plus imports as a share of gross output. Robust standard errors are clustered at the country level. PI $=$ price of investment.

*** $p<0.01, * * p<0.05, * p<0.1$ 
Table 10. Aggregate Results by Skill Level

High Skilled Middle Skilled Low Skilled

\begin{tabular}{lccc}
\hline Technology & & & \\
Relative PI & 0.0317 & $0.224^{* *}$ & -0.0293 \\
& $(0.0338)$ & $(0.104)$ & $(0.0686)$ \\
Initial Routinization & -0.001 & 0.002 & -0.0001 \\
& $(0.00110)$ & $(0.00263)$ & $(0.00187)$ \\
Relative PI * Initial Routinization & 0.0460 & $0.408^{* *}$ & -0.104 \\
& $(0.0616)$ & $(0.169)$ & $(0.146)$ \\
Global Integration & & & \\
Global Value Chain Participation & 0.0315 & $-0.811^{* *}$ & -0.100 \\
& $(0.0989)$ & $(0.354)$ & $(0.187)$ \\
Financial Integration & $0.839^{* * *}$ & -0.195 & -0.316 \\
& $(0.266)$ & $(0.301)$ & $(0.339)$ \\
Policies and Institutions & & & \\
Corporate Taxation & 0.0268 & -0.237 & -0.0701 \\
& $(0.0576)$ & $(0.151)$ & $(0.0847)$ \\
Relative Skill Supply & $0.666^{* *}$ & 1.738 & -0.156 \\
& $(0.308)$ & $(1.545)$ & $(2.152)$ \\
Number of Observations & 37 & 37 & 37 \\
$R^{2}$ & 0.299 & 0.351 & 0.047 \\
\hline
\end{tabular}

Source: IMF staff calculations.

Note: All variables (except for initial routinization) are expressed as long-term changes. Robust standard errors are clustered at the country level. PI = price of investment.

$* * * p<0.01, * * p<0.05, * p<0.1$ 
Table 11. Sectoral Results by Skill Level

\begin{tabular}{|c|c|c|c|c|c|c|}
\hline & \multicolumn{2}{|c|}{ Tigh Skilled } & \multicolumn{2}{|c|}{ Middle Skilled } & \multicolumn{2}{|c|}{ Low Skilled } \\
\hline & $(1)$ & $(2)$ & $(3)$ & $(4)$ & $(5)$ & $(6)$ \\
\hline \multicolumn{7}{|l|}{ Technology } \\
\hline Relative PI & $\begin{array}{c}-0.00778 \\
(0.0113)\end{array}$ & $\begin{array}{c}0.0152 \\
(0.0124)\end{array}$ & $\begin{array}{l}-0.0276 \\
(0.0198)\end{array}$ & $\begin{array}{l}-0.0143 \\
(0.0215)\end{array}$ & $\begin{array}{c}0.0152 \\
(0.0254)\end{array}$ & $\begin{array}{c}0.0337 \\
(0.0306)\end{array}$ \\
\hline Initial Routinization & $\begin{array}{l}-0.00134 \\
(0.00144)\end{array}$ & $\begin{array}{l}-0.00233 \\
(0.00144)\end{array}$ & $\begin{array}{c}0.00118 \\
(0.00256)\end{array}$ & $\begin{array}{l}0.000386 \\
(0.00252)\end{array}$ & $\begin{array}{l}-0.00216 \\
(0.00314)\end{array}$ & $\begin{array}{l}-0.00223 \\
(0.00339)\end{array}$ \\
\hline Relative PI * Initial Routinization & $\begin{array}{c}0.0147 \\
(0.0233)\end{array}$ & $\begin{array}{c}0.0142 \\
(0.0217)\end{array}$ & $\begin{array}{l}0.0755 * \\
(0.0405)\end{array}$ & $\begin{array}{c}0.0795 * * \\
(0.0376)\end{array}$ & $\begin{array}{l}-0.0390 \\
(0.0481)\end{array}$ & $\begin{array}{l}-0.0235 \\
(0.0488)\end{array}$ \\
\hline \multicolumn{7}{|l|}{ Global Integration } \\
\hline Global Value Chain Participation & $\begin{array}{l}1.70 \mathrm{e}-05 \\
(0.00210)\end{array}$ & $\begin{array}{c}0.000152 \\
(0.00207)\end{array}$ & $\begin{array}{c}0.00430 \\
(0.00329)\end{array}$ & $\begin{array}{c}0.00117 \\
(0.00326)\end{array}$ & $\begin{array}{l}-0.00144 \\
(0.00399)\end{array}$ & $\begin{array}{l}-0.00125 \\
(0.00425)\end{array}$ \\
\hline \multicolumn{7}{|l|}{ Fixed Effects } \\
\hline Country Fixed Effects & Y & $\mathrm{Y}$ & $\mathrm{Y}$ & $\mathrm{Y}$ & $\mathrm{Y}$ & Y \\
\hline Sector Fixed Effects & $\mathrm{N}$ & $\mathrm{Y}$ & $\mathrm{N}$ & $\mathrm{Y}$ & $\mathrm{N}$ & $\mathrm{Y}$ \\
\hline Number of Observations & 289 & 289 & 297 & 297 & 275 & 275 \\
\hline$R^{2}$ & 0.143 & 0.381 & 0.201 & 0.435 & 0.059 & 0.214 \\
\hline
\end{tabular}

Source: IMF staff calculations.

Note: All variables (except for initial routinization) are expressed as long-term changes. Robust standard errors are clustered at the country level. PI = price of investment.

$* * * p<0.01, * * p<0.05, * p<0.1$ 
Table 12. Sectoral Results by Skill Level, Controlling for Skill Composition

\begin{tabular}{|c|c|c|c|}
\hline & High Skilled & Middle Skilled & Low Skilled \\
\hline \multicolumn{4}{|l|}{ Technology } \\
\hline \multirow[t]{2}{*}{ Relative PI } & 0.00345 & 0.00147 & 0.0393 \\
\hline & $(0.0112)$ & $(0.0190)$ & $(0.0284)$ \\
\hline \multirow[t]{2}{*}{ Initial Routinization } & -0.00144 & 0.000979 & -0.00378 \\
\hline & $(0.00129)$ & $(0.00222)$ & $(0.00315)$ \\
\hline \multirow[t]{2}{*}{ Relative PI * Initial Routinization } & 0.0271 & $0.0649 *$ & -0.0404 \\
\hline & $(0.0195)$ & $(0.0331)$ & $(0.0452)$ \\
\hline \multicolumn{4}{|l|}{ Global Integration } \\
\hline \multirow[t]{2}{*}{ Global Value Chain Participation } & -0.00864 & -0.000356 & -0.0108 \\
\hline & $(0.0152)$ & $(0.0265)$ & $(0.0361)$ \\
\hline \multicolumn{4}{|l|}{ Skill Composition } \\
\hline \multirow[t]{2}{*}{ Skill Share in Total Hours } & $0.511 * * *$ & $0.733 * * *$ & $0.712 * * *$ \\
\hline & $(0.0650)$ & $(0.0846)$ & $(0.114)$ \\
\hline \multicolumn{4}{|l|}{ Fixed Effects } \\
\hline Country Fixed Effects & $\mathrm{Y}$ & $\mathrm{Y}$ & $\mathrm{Y}$ \\
\hline Sector Fixed Effects & $\mathrm{Y}$ & $\mathrm{Y}$ & $\mathrm{Y}$ \\
\hline Number of Observations & 289 & 297 & 275 \\
\hline$R^{2}$ & 0.506 & 0.564 & 0.329 \\
\hline
\end{tabular}

Source: IMF staff calculations.

Note: All variables (except for initial routinization) are expressed as long-term changes. Robust standard errors are clustered at the country level. PI $=$ price of investment.

$* * * p<0.01, * * p<0.05, * p<0.1$ 
Table 13. Sectoral Results by Skill Level, Controlling for Policy and Institutions Variables

(1) (2)

High Skilled Middle Skilled

Technology

Relative PI

Initial Routinization

Relative PI * Initial Routinization

Global Integration

Global Value Chain Participation

Financial Integration

Policies and Institutions

Unionization

Employment Protection Legislation

Corporate Taxation

Sector Fixed Effects

Number of Observations

$R^{2}$

Source: IMF staff calculations.

Note: All variables (except for initial routinization) are expressed as long-term changes. Robust standard errors are clustered at the country level. PI $=$ price of investment.

$* * * p<0.01, * * p<0.05, * p<0.1$

(3)

(4)

(5)

Low Skilled High Skilled Middle Skilled Low Skilled

\begin{tabular}{|c|c|c|c|c|c|}
\hline & & & -0.00369 & -0.0209 & 0.00140 \\
\hline & & & $(0.0113)$ & $(0.0198)$ & $(0.0259)$ \\
\hline & & & -0.00189 & 0.000193 & -0.00111 \\
\hline & & & $(0.00140)$ & $(0.00249)$ & $(0.00315)$ \\
\hline & & & 0.00793 & $0.0659 *$ & -0.0303 \\
\hline & & & $(0.0226)$ & $(0.0392)$ & $(0.0480)$ \\
\hline & & & -0.00237 & -0.0187 & 0.00372 \\
\hline & & & $(0.0171)$ & $(0.0307)$ & $(0.0376)$ \\
\hline & & & $0.805 * * *$ & $1.52 * * *$ & $-0.689^{*}$ \\
\hline & & & $(0.182)$ & $(0.334)$ & $(0.395)$ \\
\hline$-0.00635 *$ & $-0.0226 * * *$ & -0.00630 & -0.00398 & -0.00735 & $-0.0162 *$ \\
\hline$(0.00363)$ & $(0.00797)$ & $(0.00913)$ & $(0.00428)$ & $(0.00763)$ & (0.00939) \\
\hline-0.00241 & 0.00112 & -0.00774 & & & \\
\hline$(0.00331)$ & $(0.00718)$ & $(0.00800)$ & & & \\
\hline$-1.28 \mathrm{e}-05$ & $5.86 e-05$ & -0.000566 & & & \\
\hline$(0.000382)$ & $(0.000841)$ & $(0.000938)$ & & & \\
\hline $\mathrm{Y}$ & $\mathrm{Y}$ & $\mathrm{Y}$ & $\mathrm{Y}$ & $\mathrm{Y}$ & $\mathrm{Y}$ \\
\hline 373 & 382 & 357 & 357 & 365 & 342 \\
\hline 0.164 & 0.120 & 0.050 & 0.214 & 0.237 & 0.069 \\
\hline
\end{tabular}




\section{Annex 5. Appendix figures}

Appendix Figure 1. Estimated Trends in Labor Shares across the World (Percentage points per 10 years)

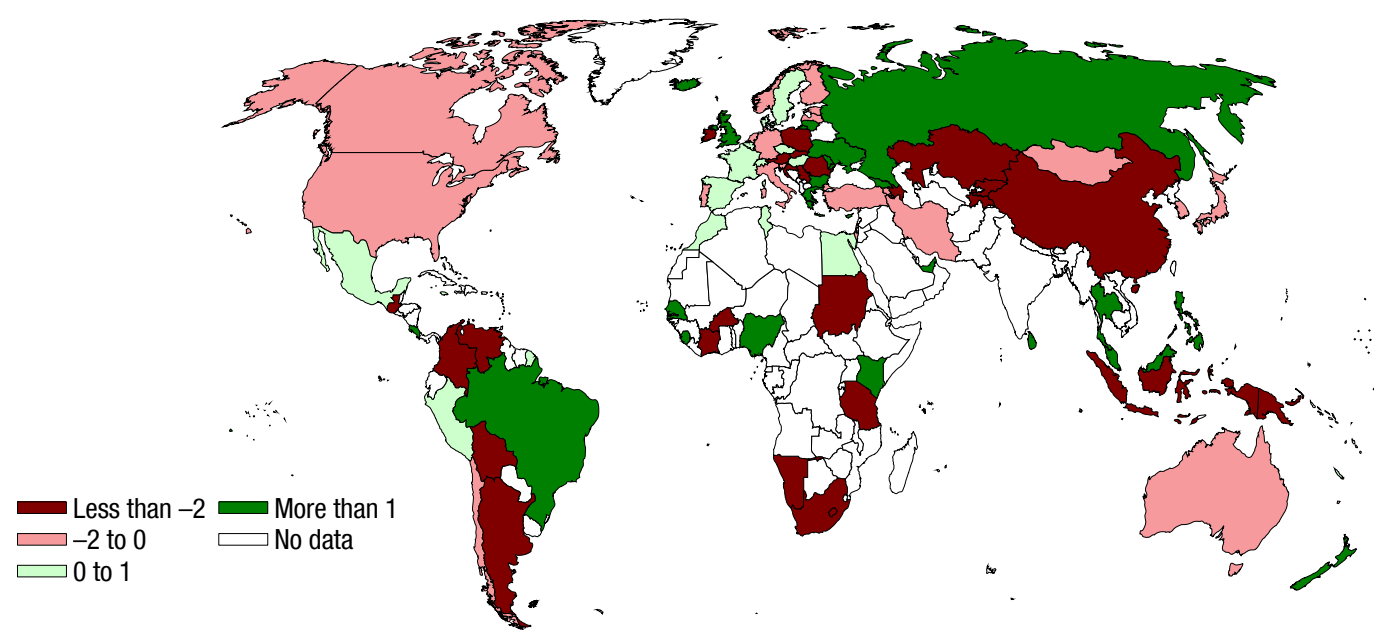

Sources: National authorities; and IMF staff calculations.

Note: This world map shows the labor share trend of countries with at least 10 years of data, starting in 1991. 
Appendix Figure 2. Heterogeneity in the Evolution of Key Drivers of the Labor Share

(Percentage points)
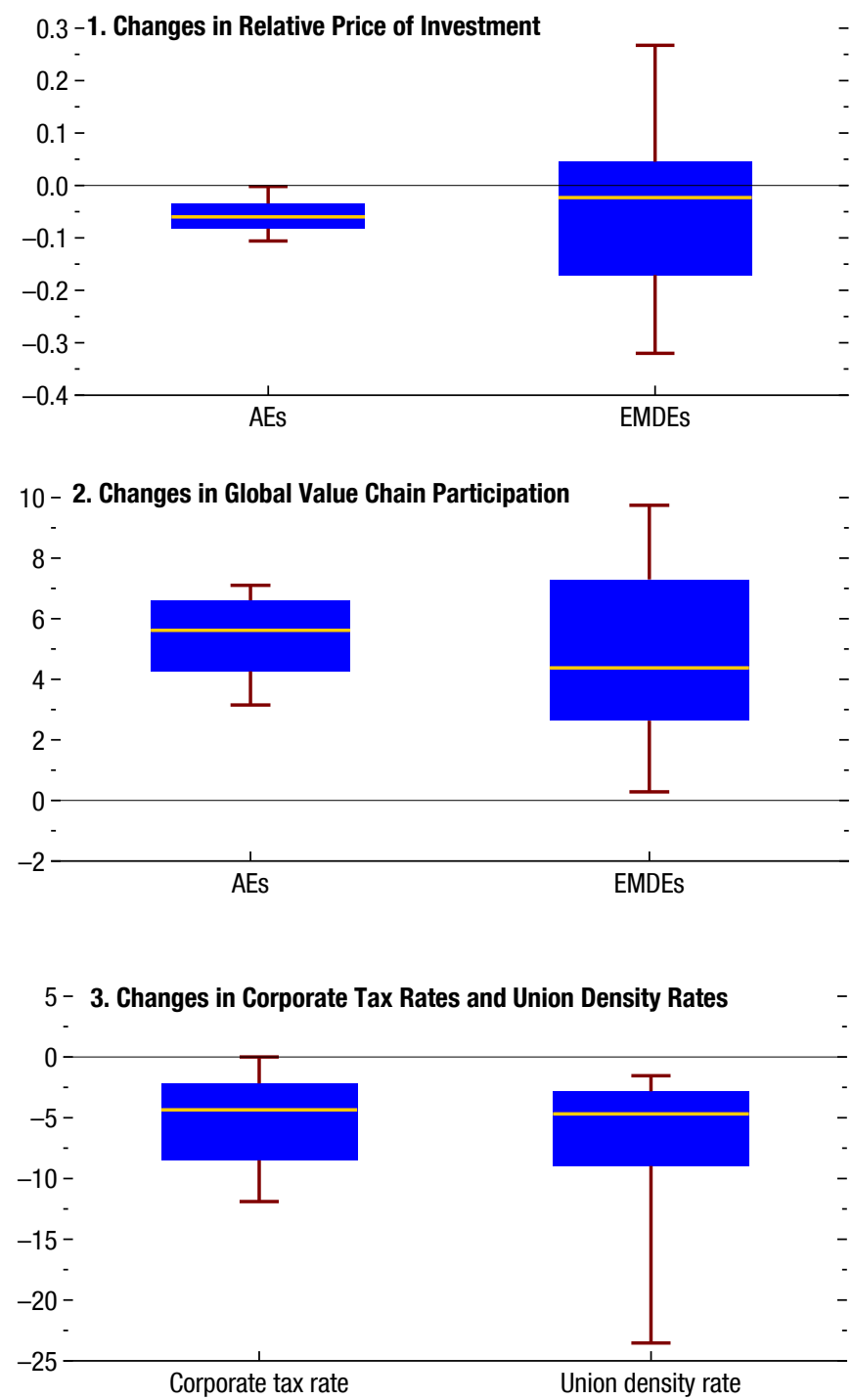

Sources: Eora Multi-Region Input-Output database; and IMF staff calculations. Note: The horizontal line inside each box represents the median; the upper and lower edges of each box show the top and bottom quartiles; and the red markers denote the top and bottom deciles. Changes are shown in units per 10 years. AEs = advanced economies; EMDEs = emerging market and developing economies. 


\section{REFERENCES}

Acemoglu, Daron, and David H. Autor. 2011. "Skill, Tasks and Technologies: Implications for Employment and Earnings." In Handbook of Labor Economics, Volume 4. Amsterdam: Elsevier.

Acemoglu, Daron, and Pascual Restrepo. 2016. "The Race Between Machine and Man: Implications of Technology for Growth, Factor Shares and Employment." NBER Working Paper 22252, National Bureau of Economic Research, Cambridge, MA.

Allen, Robert C. 2003. "Poverty and Progress in Early Modern Europe." Economic History Review 56 (3): 403-33.

- 2005. "Capital Accumulation, Technological Change, and the Distribution of Income during the British Industrial Revolution." University of Oxford, Department of Economics Discussion Paper Series 239, Oxford, United Kingdom.

—. 2007. "Engel's Pause: A Pessimist's Guide to the British Industrial Revolution." University of Oxford, Department of Economics Discussion Paper Series 315, Oxford, United Kingdom.

- 2011. Global Economic History: A Very Short Introduction. Oxford, United Kingdom: Oxford University Press.

Amiti, Mary, and Shang-Jin Wei. 2009. "Service Offshoring and Productivity: Evidence from the US." World Economy 32 (2): 203-20.

Arrow, Kenneth, Hollis Chenery, Bagicha Minhas, and Robert Solow. 1961. "Capital-Labor Substitution and Economic Efficiency." Review of Economics and Statistics 43 (3): 225-50.

Autor, David H., and David Dorn. 2013. "The Growth of Low-Skill Service Jobs and the Polarization of the US Labor Market." American Economic Review 103 (5): 1553-97.

Autor, David H., David Dorn, and Gordon H. Hanson. 2016. "The China Shock: Learning from Labor-Market Adjustment to Large Changes in Trade." Annual Review of Economics 8: 205-40.

Autor, David H., David Dorn, Lawrence F. Katz, Christina Patterson, and John Van Reenen. 2017. "Concentrating on the Fall of the Labor Share." NBER Working Paper 23108, National Bureau of Economic Research, Cambridge, MA. 
Autor, David H., Frank Levy, and Richard J. Murnane. 2003. "Computer-Based Technological Change and Skill Demands: Reconciling the Perspectives of Economists and Sociologists." In Low-Wage America: How Employers Are Reshaping Opportunity in the Workplace. New York, NY: Russell Sage Foundation.

Baldwin, Richard. 2016. The Great Convergence: Information Technology and the New Globalization. Cambridge, MA: Belknap Press.

Berg, Andrew G., Edward F. Buffie, and Luis-Felipe Zanna. Forthcoming. "Robots, Growth and Inequality: Should We Fear the Robot Revolution? (The Correct Answer is Yes).” IMF Working Paper, International Monetary Fund, Washington, DC.

Berg, Andrew G., and Jonathan D. Ostry. 2011. "Inequality and Unsustainable Growth: Two Sides of the Same Coin?” IMF Staff Discussion Note 11/08, International Monetary Fund, Washington, DC.

Berman, Eli, John Bound, and Zvi Griliches. 1994. "Changes in the Demand for Skilled Labor within U.S. Manufacturing Industries: Evidence from the Annual Survey of Manufacturing." Quarterly Journal of Economics 109 (2): 367-97.

Blanchard, Olivier. 1997. "The Medium Run.” Brookings Papers on Economic Activity (2): 89-158.

—, and Francesco Giavazzi. 2003. "Macroeconomic Effects of Regulation and Deregulation in Goods and Labor Markets." Quarterly Journal of Economics 118 (3): 879-907.

Blinder, Alan S., and Alan B. Krueger. 2013. "Alternative Measures of Offshorability: A Survey Approach.” Journal of Labor Economics 31 (1): 97-128.

Boz, Emine, Luis Cubeddu, and Maurice Obstfeld. 2017. "Revisiting the Paradox of Capital”, VoxEU.org, http://voxeu.org/article/revisiting-paradox-capital

Brandolini, Andrea, and Giovanni Vecchi. 2011. "The Well-Being of Italians: A Comparative Historical Approach.” Bank of Italy Economic History Working Papers, Rome.

Bridgman, Benjamin. 2014. “Is Labor's Loss Capital's Gain? Gross versus Net Labor Shares." Bureau of Economic Analysis, Washington, DC. https://bea.gov/papers/pdf/laborshare1410.pdf.

Brynjolfsson, Erik, and Andrew McAfee. 2014. The Second Machine Age: Work, Progress, and Prosperity in a Time of Brilliant Technologies. New York: W. W. Norton \& Co. 
Bythell, Duncan. 1969. The Handloom Weavers: A Study in the English Cotton Industry during the Industrial Revolution. Cambridge University Press, Cambridge, United Kingdom.

Caselli, Francesco, and James Feyrer. 2007. "The Marginal Product of Capital.” Quarterly Journal of Economics 122 (2): 535-68.

Cho, Ilhyun. 2016. "Offshoring and Labor Share in Manufacturing Industries in Developed Countries." Working Paper, University of California, Davis.

Clements, Benedict, Ruud de Mooij, Sanjeev Gupta, and Michael Keen. 2015. Inequality and Fiscal Policy. Washington, DC: International Monetary Fund.

Costinot, Arnaud, and Andrés Rodríguez-Clare. 2013. "Trade Theory with Numbers: Quantifying the Consequences of Globalization.” NBER Working Paper 18896, National Bureau of Economic Research, Cambridge, MA.

Council of Economic Advisers. 2014. "The Economic Report of the President together with the Annual Report of the Council of Economic Advisers." Washington, DC.

2016. "Labor Market Monopsony: Trends, Consequences, and Policy Responses." https://obamawhitehouse.archives.gov/sites/default/files/page/files/20161025_ monopsony_labor_mrkt_cea.pdf.

Dao, Mai Chi, Mitali Das, Zsoka Koczan, and Weicheng Lian. Forthcoming. "Why Is Labor Receiving a Smaller Share of Global Income? Theory and Empirical Evidence." Unpublished.

Das, Mitali, and Benjamin Hilgenstock. Forthcoming. "The Exposure to Routinization in Developed and Developing Economies." Unpublished.

Ebenstein, Avraham, Ann Harrison, Margaret McMillan, and Shannon Phillips. 2014. "Estimating the Impact of Trade and Offshoring on American Workers Using the Current Population Surveys." Review of Economics and Statistics 96 (4): $581-95$.

Eden, Maya, and Paul Gaggl. 2015. "On the Welfare Implications of Automation." Policy Research Working Paper 7487, World Bank, Washington, DC.

Elsby, Michael W., Bart Hobijn, and Ayşegül Şahin. 2013. "The Decline of the US Labor Share." Brookings Papers on Economic Activity (2): 1-63.

Fajgelbaum, Pablo D., and Amit K. Khandelwal. 2014. "Measuring the Unequal Gains from Trade.” NBER Working Paper 20331, National Bureau of Economic Research, Cambridge, MA. 
Feenstra, Robert C., and Gordon H. Hanson. 1997. "Foreign Direct Investment and Relative Wages: Evidence from Mexico's Maquiladoras.” Journal of International Economics 42: 371-93.

1999. "The Impact of Outsourcing and High-Technology Capital on Wages: Estimates for the United States, 1979-1990." Quarterly Journal of Economics 114 (3): 907-40.

Fleck, Susan, John Glaser, and Shawn Sprague. 2011. "The Compensation-Productivity Gap: A Visual Essay." Monthly Labor Review (January): 57-69.

Fochesato, Mattia. 2014. "Demographic Shocks, Labor Institutions and Wage Divergence in Early Modern Europe." http://econ.sciencespo.fr/sites/default/files/file/mattia-fochesato.pdf.

Francese, Maura, and Carlos Mulas-Granados. 2015. "Functional Income Distribution and Its Role in Explaining Inequality.” IMF Working Paper 15/244, International Monetary Fund, Washington, DC.

Goldin, Claudia, and Lawrence F. Katz. 1998. "The Origins of Technology-Skill Complementarity." Quarterly Journal of Economics 113 (3): 693-732.

Gollin, Douglas. 2002. "Getting Income Shares Right.” Journal of Political Economy 110 (2): $458-74$.

Goos, Maarten, Alan Manning, and Anna Salomons. 2014. "Explaining Job Polarization: Routine-Biased Technological Change and Offshoring." American Economic Review 104 (8): 2509-26.

Grant, Oliver Wavell. 2002. "Does Industrialization Push Up Inequality? New Evidence on the Kuznets Curve from Nineteenth Century Prussian Tax Statistics." Oxford Economic and Social History Working Papers 48, University of Oxford, Oxford, United Kingdom.

Greenwood, Jeremy. 1997. The Third Industrial Revolution: Technology, Productivity, and Income Inequality. Washington, DC: AEI Press.

Grossman, Gene M., and Esteban Rossi-Hansberg. 2008. “Trading Tasks: A Simple Theory of Offshoring.” American Economic Review 98 (5): 1978-97.

Gwartney, James, Robert Lawson, and Joshua Hall. 2016. "Economic Freedom of the World 2016 Annual Report.” Fraser Institute:

https://www.fraserinstitute.org/studies/economic-freedom-of-the-world-2016annual-report 
Harrison, Ann. 2002. "Has Globalization Eroded Labor's Share? Some Cross-Country Evidence." University of California, Berkeley, and National Bureau of Economic Research. http://www.iadb.org/res/publications/pubfiles/pubS-FDI9.pdf.

Hicks, John R. 1932. Theory of Wages. London: Macmillan.

Hobsbawm, Eric, and George Rude. 2001. Captain Swing. Phoenix, AZ: Phoenix Press.

Hsieh, Chang-Tai, and Peter J. Klenow. 2007. "Relative Prices and Relative Prosperity." American Economic Review 97 (3): 562-85.

Hummels, David, Rasmus Jorgensen, Jakob Munch, and Chong Xiang. 2014. "The Wage and Employment Effects of Outsourcing: Evidence from Danish Matched WorkerFirm Data." American Economic Review 194: 1597-629.

International Labour Organization (ILO). 2012. "Global Estimate of Forced Labour 2012: Results and Methodology.” International Labour Office, Geneva.

_. 2015a. "Global Wage Report: Wages and Income Inequality." International Labour Office, Geneva.

.2015b. "Income Inequality and Labour Income Share in G20 Countries: Trends, Impacts and Causes." Note for the G20, 2015 prepared by the International Labour Organization, International Monetary Fund (IMF), Organisation for Economic Co-operation and Development (OECD), World Bank Group (WBG).

_. 2015c. "Global Wage Report 2014/15: Wages and Income Inequality." International Labour Office, Geneva.

International Monetary Fund (IMF). 2017a. "Gone with the Headwinds: Global Productivity.” Staff Discussion Note, Washington, DC.

International Monetary Fund (IMF). 2017b. "Understanding the Downward Trend in Labor Income Shares", Chapter 3 in World Economic Outlook, April 2017, Washington, DC.

— World Bank, and World Trade Organization. Forthcoming. "Making Trade an Engine of Growth for All: The Case for Trade and for Policies to Facilitate Adjustment," Note for the G20, 2017.

Jaumotte, Florence, and Irina Tytell. 2007. "How Has the Globalization of Labor Affected the Labor Income Share in Advanced Countries?" IMF Working Paper 07/298, International Monetary Fund, Washington, DC. 
Jaumotte, Florence, Subir Lall, and Chris Papageorgiou. 2013. "Rising Income Inequality: Technology, or Trade and Financial Globalization?" IMF Economic Review 61 (2): 271-309.

Jiang, Hao, and Weicheng Lian. Forthcoming. "Empirical Estimates of the Elasticity of Substitution". Unpublished.

Jones, Charles I., and Paul M. Romer. 2009. "The New Kaldor Facts: Ideas, Institutions, Population, and Human Capital.” NBER Working Paper 15094, National Bureau of Economic Research, Cambridge, MA.

Kaldor, Nicholas. 1957. “A Model of Economic Growth.” Economic Journal 67 (268): 591624.

Karabarbounis, Loukas, and Brent Neiman. 2014. "The Global Decline of the Labor Share." Quarterly Journal of Economics 129 (1): 61-103.

Katz, Lawrence F., and Alan B. Krueger. 1998. “Computing Inequality: Have Computers Changed the Labor Market?” Quarterly Journal of Economics 113 (4): 1169213.

Katz, Lawrence F., and Robert A. Margo. 2013. "Technical Change and the Relative Demand for Skilled Labor: The United States in Historical Perspective." NBER Working Paper 18752. National Bureau of Economic Research, Cambridge, MA.

Keynes, John Maynard. 1932. "Economic Possibilities for our Grandchildren." Essays in Persuasion. New York. Harcourt, Brace and Company.

Koopman, Robert, Zhi Wang, and Shang-Jin Wei. 2014. "Tracing Value-Added and Double Counting in Gross Exports." American Economic Review 104 (2): 459-94.

Kramarz, Francis. 2016. "Offshoring, Wages, and Employment: Evidence from Data Matching Imports, Firms, and Workers." In The Factor-Free Economy. Oxford, United Kingdom: Oxford University Press.

Krusell, Per. 1998. "Investment-Specific R and D and the Decline in the Relative Price of Capital." Journal of Economic Growth 3 (2): 131-41.

—_ Lee E. Ohanian, José-Victor Ríos-Rull, and Giovanni L. Violante. 2000. "Capitalskill Complementarity and Inequality: A Macroeconomic Analysis." Econometrica 68 (5): 1029-53.

Kuznets, Simon. 1955. "Economic Growth and Income Inequality." American Economic Review 45: 1-28. 
Lian, Weicheng. Forthcoming. "Relative Cost of Capital, Offshoring, and Labor Shares of Income in Advanced Economies and Emerging Market Economies." Unpublished.

Lindert, Peter H. 2000. "Three Centuries of Inequality in Britain and America." In Handbook of Income Distribution. Amsterdam: Elsevier.

—_ and Jeffrey G. Williamson. 1983. "Reinterpreting Britain's Social Tables, 16881913." Explorations in Economic History 20: 94-109.

Lyons, John S. 1989. "Family Response to Economic Decline: Handloom Weavers in Early Nineteenth-Century Lancashire." Research in Economic History 12: 45-91.

Milanovic, Branko. 2016. Global Inequality: A New Approach for the Age of Globalization. Cambridge, MA: Belknap Press.

— Economic Journal 121 (551): 255-72.

Minami, Ryoshin. 1998. "Economic Development and Income Distribution in Japan: An Assessment of the Kuznets Hypothesis." Cambridge Journal of Economics 22: $39-58$.

—. 2008. "Income Distribution in Japan: Historical Perspective and Its Implications." Japan Labor Review 5 (4): 5-20.

Mokyr, Joel. 2002. The Gifts of Athena: Historical Origins of the Knowledge Economy. Princeton, NJ: Princeton University Press.

—, Chris Vickers, and Nicolas L. Ziebarth. 2015. "The History of Technological Anxiety and the Future of Economic Growth: Is This Time Different?" Journal of Economic Perspectives 29 (3): 31-50.

Mortimer, Thomas. 1772. The Elements of Commerce, Politics and Finances. London: Hooper.

Nordhaus, William D. 1972. "The Worldwide Wage Explosion” Brookings Papers on Economic Activity 2: 431-65.

_ 2007. "Two Centuries of Productivity Growth in Computing." Journal of Economic History 67 (1): 128-59.

Obstfeld, Maurice. 2016. “Get on Track with Trade.” Finance \& Development 53 (4). and A. Taylor. 2004. Global Capital Markets: Integration, Crisis, and Growth. 
Cambridge, United Kingdom: Cambridge University Press.

Ollivaud, Patrice, Yvan Guillemette, and David Turner. 2016. "Links between Weak Investment and the Slowdown in Productivity and Potential Output Growth across the OECD.” OECD Economics Department Working Papers, Organisation for Economic Co-operation and Development, Paris.

Organisation for Economic Co-operation and Development. 2011. "Special Focus: Inequality in Emerging Economies (EEs)." Divided We Stand, Why Inequality Keeps Rising. OECD. Paris.

Organisation for Economic Co-operation and Development. 2012. "Labour Losing to Capital: What Explains the Declining Labour Share?" Chapter 3 in $O E C D$ Employment Outlook, Paris.

Pierce, Justin, and Peter Schott. 2016. "The Surprisingly Swift Decline of U.S. Manufacturing Employment.” American Economic Review 106: 1632-62.

Ricardo, David. 1821 [1971]. Principles of Political Economy, 3rd edition, edited by R. M. Hartwell. Harmondsworth: Pelican Classics.

Robinson, Joan. 1933. The Economics of Imperfect Competition. London: Macmillan.

Rodrigues, Francisco, and Arjun Jayadev. 2010. "The Declining Labor Share of Income." Human Development Research Paper 2010/36, United Nations Development Programme, New York.

Rodrik, Dani. 1998. "Globalization, Social Conflict and Economic Growth." World Economy 21: $143-58$.

Rognlie, Matthew. 2015. "Deciphering the Fall and Rise in the Net Capital Share: Accumulation or Scarcity?" Brookings Papers on Economic Activity (1): 169.

Ryckbosch, Wouter. 2014. "Economic Inequality and Growth before the Industrial Revolution: A Case Study of the Low Countries (14th-19th century)." Dondena Working Paper, Bocconi University, Milan.

Soltow, Lee, and Jan Luiten van Zanden. 1998. Income and Wealth Inequality in the Netherlands 16th-20th Century. Het Spinhuis, Amsterdam.

Steuart, James. 1767. An Inquiry into the Principles of Political Economy. Printed for A. Millar, and T. Cadell, London.

Stevenson, John. 1979. Popular Disturbances in England, 1700-1870. New York: Longman. 
Thomis, Malcolm. 1970. The Luddites. New York: Schocken.

van Zanden, Jan Luiten. 1995. "Tracing the Beginning of the Kuznets Curve: Western Europe during the Early Modern Period." Economic History Review 48 (4): 123.

Wacziarg, Romain, and Karen Horn Welch. 2008. "Trade Liberalization and Growth: New Evidence.” World Bank Economic Review 22 (2): 187-231.

Wolff, Edward. 2010. "Recent Trends in Household Wealth in the United States: Rising Debt and the Middle-Class Squeeze: An Update to 2007." https://papers.ssrn.com/sol3/papers.cfm?abstract_id=1585409.

World Bank Group. 2016. “Taking on Inequality.” World Bank Group Poverty and Shared Prosperity 2016 Report. 